\title{
Extrasynaptic NMDA Receptors on Rod Pathway Amacrine Cells: Molecular Composition, Activation, and Signaling
}

\author{
@Dargaret L. Veruki, ${ }^{1}$ Yifan Zhou, ${ }^{1}$ Áurea Castilho, ${ }^{1}{ }^{\circledR}$ Catherine W. Morgans, ${ }^{2}$ and $\oplus^{\circ E s p e n ~ H a r t v e i t ~}{ }^{1}$ \\ ${ }^{1}$ University of Bergen, Department of Biomedicine, N-5009 Bergen, Norway, and ${ }^{2}$ Department of Physiology and Pharmacology, Oregon Health and Science \\ University, Portland, Oregon 97239
}

In the rod pathway of the mammalian retina, axon terminals of glutamatergic rod bipolar cells are presynaptic to AII and A17 amacrine cells in the inner plexiform layer. Recent evidence suggests that both amacrines express NMDA receptors, raising questions concerning molecular composition, localization, activation, and function of these receptors. Using dual patch-clamp recording from synaptically connected rod bipolar and AII or A17 amacrine cells in retinal slices from female rats, we found no evidence that NMDA receptors contribute to postsynaptic currents evoked in either amacrine. Instead, NMDA receptors on both amacrine cells were activated by ambient glutamate, and blocking glutamate uptake increased their level of activation. NMDA receptor activation also increased the frequency of GABAergic postsynaptic currents in rod bipolar cells, suggesting that NMDA receptors can drive release of GABA from A17 amacrines. A striking dichotomy was revealed by pharmacological and immunolabeling experiments, which found GluN2B-containing NMDA receptors on AII amacrines and GluN2A-containing NMDA receptors on A17 amacrines. Immunolabeling also revealed a clustered organization of NMDA receptors on both amacrines and a close spatial association between GluN2B subunits and connexin 36 on AII amacrines, suggesting that NMDA receptor modulation of gap junction coupling between these cells involves the GluN2B subunit. Using multiphoton $\mathrm{Ca}^{2+}$ imaging, we verified that activation of NMDA receptors evoked an increase of intracellular $\mathrm{Ca}^{2+}$ in dendrites of both amacrines. Our results suggest that AII and A17 amacrines express clustered, extrasynaptic NMDA receptors, with different and complementary subunits that are likely to contribute differentially to signal processing and plasticity.

Key words: amacrine cells; GluN2A; GluN2B; NMDA receptors; patch-clamp; retina

Significance Statement

Glutamate is the most important excitatory neurotransmitter in the CNS, but not all glutamate receptors transmit fast excitatory signals at synapses. NMDA-type glutamate receptors act as voltage- and ligand-gated ion channels, with functional properties determined by their specific subunit composition. These receptors can be found at both synaptic and extrasynaptic sites on neurons, but the role of extrasynaptic NMDA receptors is unclear. Here, we demonstrate that retinal AII and A17 amacrine cells, postsynaptic partners at rod bipolar dyad synapses, express extrasynaptic (but not synaptic) NMDA receptors, with different and complementary GluN2 subunits. The localization of GluN2A-containing receptors to A17s and GluN2B-containing receptors to AIIs suggests a mechanism for differential modulation of excitability and signaling in this retinal microcircuit.

\section{Introduction}

When neurotransmitter molecules are released from a neuron, they can bind to and activate heterogeneous populations of ligand-gated ion channels, typically formed by different combi-

\footnotetext{
Received Aug. 10, 2018; revised 0ct. 29, 2018; accepted Nov. 14, 2018.

Author contributions: M.L.V. and E.H. wrote the first draft of the paper; M.L.V., Y.Z., A.C., C.W.M., and E.H. edited the paper; M.L.V., C.W.M., and E.H. designed research; M.L.V., Y.Z., A.C., and E.H. performed research; E.H. contributed unpublished reagents/analytic tools; M.L.V., Y.Z., Á.C., and E.H. analyzed data; M.L.V. and E.H. wrote the paper.

This work was supported by Research Council of Norway Grants 213776 and 261914 to M.L.V. and Grants 182743, 189662, and 214216 to E.H. A research stay of C.W.M. at the University of Bergen was supported by a SPIRE visiting researcher Grant to M.L.V. Confocal imaging was performed at the Molecular Imaging Center and was supported by the Department of Biomedicine and the Faculty of Medicine at the University of Bergen. We thank Torhild Sunde for excellent technical assistance.

The authors declare no competing financial interests.
}

nations of receptor subunits. This receptor heterogeneity can be expressed within a single postsynaptic density, at different synapses received by a single neuron, and at synapses made by the same neuron with different postsynaptic targets (Shepherd and Grillner, 2018). Within a receptor family, individual receptors can differ in agonist affinity, single-channel conductance, kinetics, selectivity and permeability for specific ions, and influence on downstream signaling pathways; thus, the subunit composition

Correspondence should be addressed to Margaret L. Veruki at margaret.veruki@uib.no or Espen Hartveit at espen.hartveit@uib.no.

https://doi.org/10.1523/JNEUROSCI.2267-18.2018

Copyright $\odot 2019$ the authors $\quad 0270-6474 / 19 / 390627-24 \$ 15.00 / 0$ 
of a given receptor channel is of critical importance for the specific functional and signaling properties (Traynelis et al., 2010; Smart and Paoletti, 2012). Considerable attention has therefore been devoted to investigate how expression and regulation of receptors and receptor subunits are adapted to and contribute to the specific signal processing taking place in different microcircuits and networks.

The microcircuit formed in the mammalian retina by the rod bipolar cell and its dyad postsynaptic partners, the AII and A17 amacrine cells, is structurally and functionally well defined, plays a crucial role in visual processing (for review, see Demb and Singer, 2012), and has been identified as a target for molecular pathologies in early diabetes mellitus (Castilho et al., 2015; Moore-Dotson et al., 2016). The cellular elements of this microcircuit are easily identifiable in slice preparations; and, as such, the microcircuit provides a unique model to investigate neurotransmitter interactions. Glutamate is released from axon terminals of rod bipolar cells at specialized active zones called ribbons, with each ribbon typically presynaptic to one AII process and one A17 process (Strettoi et al., 1990). AII amacrines provide outputs to ON- and OFF-cone bipolar cells, via electrical and chemical (glycinergic) synapses, respectively (Strettoi et al., 1992, 1994), whereas A17 amacrines provide GABAergic feedback to the axon terminals of rod bipolar cells from which they receive input (reciprocal synapses) (for review, see Diamond and Grimes, 2014). Glutamate from rod bipolar cells activates non-NMDAtype glutamate receptors on both AII and A17 amacrines (Hartveit, 1999; Singer and Diamond, 2003; Veruki et al., 2003; Chávez et al., 2006), and it was originally assumed that these cells did not express NMDA receptors (Boos et al., 1993; Menger and Wässle, 2000). There is increasing evidence, however, that both AII and A17 amacrines express functional NMDA receptors (Hartveit and Veruki, 1997; Zhou and Dacheux, 2004; Kothmann et al., 2012; Zhou et al., 2016), raising questions concerning the molecular identity, localization, and function of these receptors. NMDA receptors, comprised of obligatory GluN1 subunits and either GluN2 or, less commonly, GluN3 subunits, operate as both voltage- and ligand-gated ion channels. Four different GluN2 subunits (GluN2A-D) have a strong influence on the functional properties of NMDA receptors (Monyer et al., 1994; Paoletti et al., 2013); thus, the different expression patterns of GluN2 subunits, within neurons and microcircuits, are expected to reflect different spatial and temporal requirements of glutamatergic signaling (Swanger and Traynelis, 2018).

Here, we used a combination of patch-clamp electrophysiology, pharmacology, immunocytochemical labeling, and multiphoton excitation (MPE) $\mathrm{Ca}^{2+}$ imaging to investigate the NMDA receptors expressed by AII and A17 amacrine cells in rat retina. Our results suggest that NMDA receptors on both amacrines have a clustered, extrasynaptic location and do not contribute to the synaptic response evoked by input from rod bipolar cells. Instead, NMDA receptors in both cell types are activated by ambient glutamate, with increased activation following block of glutamate uptake. Furthermore, activation of NMDA receptors evokes an increase of intracellular $\mathrm{Ca}^{2+}$ within dendritic processes of both cell types and increases the frequency of discrete postsynaptic currents in rod bipolar cells. Most strikingly, the amacrine cells express NMDA receptors with different and complementary subunits, with AIIs expressing GluN2B subunits and A17s expressing GluN2A subunits. The complementary subunit composition of NMDA receptors in these amacrine cells within the same microcircuit suggests a mechanism for differential contributions to excitability, signaling, and plasticity.

\section{Materials and Methods}

Retinal slice preparation and visual targeting of neurons. General aspects of the methods have previously been described in detail (Zhou et al., 2016). Female rats (Wistar HanTac; 4-7 weeks postnatal; Taconic Bioscience) had ad libitum access to food and water and were kept on a 12/12 light/ dark cycle. The use of animals in this study was performed under the approval of and in accordance with the regulations of the Animal Laboratory Facility at the Faculty of Medicine at the University of Bergen (accredited by AAALAC International). Animals were deeply anesthetized with isoflurane (IsoFlo vet 100\%; Abbott Laboratories) in $100 \% \mathrm{O}_{2}$ and killed by cervical dislocation. After dissecting out the retina, vertical slices were cut at $\sim 100$ to $\sim 150 \mu \mathrm{m}$ and visualized with a $40 \times$ or $60 \times$ water-immersion objective and infrared differential interference contrast (IR-DIC) or IR Dodt gradient contrast (Luigs \& Neumann) videomicroscopy (Axioskop FS2, Carl Zeiss; BX51 WI, Olympus). For experiments with MPE microscopy, the slices were visualized using a custom-modified Movable Objective Microscope (Sutter Instrument) with a $20 \times$ water-immersion objective (0.95 NA; Olympus) and IR (780 $\mathrm{nm}$ LED, M780L2; Thorlabs) Dodt gradient contrast videomicroscopy. Most recordings were performed at room temperature $\left(22^{\circ} \mathrm{C}-25^{\circ} \mathrm{C}\right)$. Some experiments were performed at an elevated temperature of $32.3 \pm$ $0.1^{\circ} \mathrm{C}$, using an automatic temperature control unit that continuously monitored and regulated the temperature at the recording site by heating both the perfusion solution and the recording chamber (ATR-4, Quest Scientific).

Solutions and drugs. The standard extracellular perfusing solution was continuously bubbled with $95 \% \mathrm{O}_{2} / 5 \% \mathrm{CO}_{2}$ and had the following composition (in mM): $125 \mathrm{NaCl}, 25 \mathrm{NaHCO}_{3}, 2.5 \mathrm{KCl}, 2.5 \mathrm{CaCl}_{2}, 1 \mathrm{MgCl}_{2}, 10$ glucose, $\mathrm{pH}$ 7.4. In some experiments, $\mathrm{MgCl}_{2}$ was omitted from the extracellular solution (with no replacement of the divalent cations; referred to later as $\mathrm{Mg}^{2+}$-free bath solution) to relieve the voltagedependent block of NMDA receptors (Nowak et al., 1984). For these recordings, we switched to the $\mathrm{Mg}^{2+}$-free solution at least $10 \mathrm{~min}$ before establishing the whole-cell mode. D-Serine, a coagonist of the NMDA receptor (Kleckner and Dingledine, 1988; Stevens et al., 2003), was added to the extracellular solution (200 $\mu \mathrm{M}$; Sigma-Aldrich) as indicated, to ensure adequate levels of coagonist in the presense of AMPA receptor blockers that can reduce the release of D-serine in the retina (Sullivan and Miller, 2012). In some experiments, the extracellular solution contained $20 \mathrm{~mm}$ tetraethylammonium (TEA) chloride (replacing an equimolar concentration of $\mathrm{NaCl}$ ) and $0.1 \mathrm{~mm} \mathrm{3,4-diaminopyridine} \mathrm{(3,4-DAP)} \mathrm{to}$ block voltage-gated $\mathrm{K}^{+}$channels.

In most recordings of amacrine cells (including paired recordings), recording pipettes were filled with the following (in $\mathrm{mm}$ ): 125 K-gluconate, $8 \mathrm{NaCl}, 10 \mathrm{HEPES}, 1 \mathrm{CaCl}_{2}, 5 \mathrm{EGTA}, 4$ magnesium adenosine $5^{\prime}$-triphosphate (MgATP), and $2 \mathrm{QX}-314$ (pH adjusted to 7.3 with $\mathrm{KOH}$ ). In some experiments, AIIs were filled with the following (in $\mathrm{mM}$ ): $125 \mathrm{~K}$-gluconate, $8 \mathrm{KCl}, 5 \mathrm{HEPES}, 1 \mathrm{CaCl}_{2}, 1 \mathrm{MgCl}_{2}, 5 \mathrm{EGTA}, 4$ disodium adenosine $5^{\prime}$-triphosphate ( $\mathrm{Na}_{2} \mathrm{ATP}$ ), and $2 \mathrm{QX}-314$ (pH adjusted to 7.3 with $\mathrm{KOH}$ ). For experiments with voltage ramps and stationary noise analysis, recording pipettes were filled with the following (in $\mathrm{mM}$ ): 125 $\mathrm{CsCH}_{3} \mathrm{SO}_{3}, 8 \mathrm{NaCl}, 10$ HEPES, $1 \mathrm{CaCl}_{2}, 5$ EGTA, 15 TEA-Cl, $4 \mathrm{MgATP}$ ( $\mathrm{pH}$ adjusted to 7.3 with $\mathrm{CsOH}$ ). In some voltage-ramp recordings, pipettes were instead filled with $125 \mathrm{CsCl}, 8 \mathrm{NaCl}, 10 \mathrm{HEPES}, 1 \mathrm{CaCl}_{2}, 5$ EGTA, 15 TEA-Cl, $4 \mathrm{MgATP}$ (pH adjusted to 7.3 with $\mathrm{CsOH}$ ). For paired recordings, pipettes for rod bipolar cells were filled with the following (in $\mathrm{mm}$ ): $100 \mathrm{CsCH}_{3} \mathrm{SO}_{3}, 20 \mathrm{TEA}-\mathrm{Cl}, 10$ glutamic acid, 20 HEPES, 0.2 EGTA, $4 \mathrm{MgATP}, 0.4 \mathrm{Na}_{3} \mathrm{GTP}$ (pH adjusted to 7.3 with $\mathrm{CsOH}$ ). For measuring IPSCs in rod bipolar cells, recording pipettes were filled with the following (in mM): $130 \mathrm{KCl}, 8 \mathrm{NaCl}, 1 \mathrm{CaCl}_{2}, 10$ HEPES, 5 EGTA, $4 \mathrm{MgATP}$, $0.05 \mathrm{DL}$-threo- $\beta$-benzyloxyaspartic acid (TBOA; $\mathrm{pH}$ adjusted to 7.3 with $\mathrm{KOH})$. For visualization of complete cellular morphologies with fluorescence microscopy after the recording, Lucifer yellow $(1 \mathrm{mg} / \mathrm{ml}$;

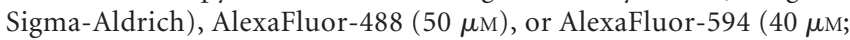
Invitrogen; Thermo Fisher Scientific) was included in the intracellular solutions. For MPE microscopy and $\mathrm{Ca}^{2+}$ imaging, pipettes were filled with the following (in $\mathrm{mM}$ ): $125 \mathrm{~K}$-gluconate, $5 \mathrm{KCl}, 8 \mathrm{NaCl}, 10$ HEPES, 4 MgATP, $\mathrm{Na}_{3}$ GTP, 0.2 Oregon Green 488 BAPTA-1 (OGB-1; Invitro- 
gen; Thermo Fisher Scientific), and 0.04 AlexaFluor-594. The data acquisition software (Patchmaster; HEKA Elektronik) corrected all holding potentials $\left(V_{\text {hold }}\right)$ for liquid junction potentials online. Theoretical liquid junction potentials were calculated with JPCalcW (Molecular Devices).

In experiments with puffer pipette application, NMDA (1 mM) was dissolved in HEPES-buffered, $\mathrm{Mg}^{2+}$-free extracellular solution containing the NMDA receptor coagonist D-serine $(200 \mu \mathrm{M})$, and was applied via pressure for $1 \mathrm{~s}$ (for details, see Zhou et al., 2016). The puffer pipette was similar in size and shape to the patch pipettes described below. For the pharmacological experiments, we first sampled baseline NMDA-evoked responses by repeated puffer pipette application of NMDA ( $V_{\text {hold }}=-60$ $\mathrm{mV})$. To avoid time- and agonist-dependent response suppression, we limited the application of NMDA to once every $60 \mathrm{~s}$ and could observe stable response amplitudes for at least 20-30 min for both types of cells (compare Zhou et al., 2016). After a stable baseline had been established, the antagonist was added to the extracellular bath solution, and we continued to apply NMDA (at $60 \mathrm{~s}$ intervals). In experiments with bath application, NMDA was added to the extracellular solution at a concentration of 50 or $100 \mu \mathrm{M}$ (with $200 \mu \mathrm{M}$ D-serine). Neurotransmitter receptor antagonists and ion channel blockers were added directly to the extracellular solution at the following concentrations (supplied by Tocris Bioscience, unless otherwise indicated): $1 \mu \mathrm{m}$ strychnine (Research Biochemicals); $10 \mu \mathrm{M}$ (-)-bicuculline methochloride; $0.3 \mu \mathrm{M}$ TTX; $10 \mu \mathrm{M}$ CNQX; $20 \mu \mathrm{M}$ (RS)-3-(2-carboxypiperazin-4-yl)-propyl-1-phosphonic acid (CPP); $50 \mu \mathrm{M}$ TBOA; $25 \mathrm{~nm}$ [[[(1S)-1-(4-bromophenyl)ethyl] amino] (1,2,3,4-tetrahydro-2,3-dioxo-5-quinoxalinyl)methyl] phosphonic acid tetrasodium hydrate (PEAQX tetrasodium hydrate, synonymous with NVP-AAM077 tetrasodium hydrate; Sigma-Aldrich); $10 \mu \mathrm{M}$ ifenprodil; $1 \mu \mathrm{M}(\alpha R, \beta S)$ - $\alpha$-(4-hydroxyphenyl)- $\beta$-methyl-4-(phenylmethyl)-1piperidinepropanol maleate (Ro 25-6981); $10 \mu \mathrm{M}$ 5-(4-bromophenyl)3-(1,2-dihydro-6-methyl-2-oxo-4-phenyl-3-quinolinyl)-4,5-dihydro$\gamma$-oxo- $1 \mathrm{H}$-pyrazole-1-butanoic acid (DQP-1105); and $10 \mu \mathrm{M} 4$-[6methoxy-2-[(1E)-2-(3-nitrophenyl)ethenyl]-4-oxo-3(4H)quinazolinyl] benzoic acid (QNZ46). For some experiments, $2 \mathrm{~mm}$ MK-801 was added to the intracellular solution.

When we tested the effect of extracellular $\mathrm{Zn}^{2+}$ on NMDA-evoked responses, we added $10 \mathrm{~mm}$ tricine (Sigma-Aldrich) to the extracellular solution to chelate trace amounts of contaminating $\mathrm{Zn}^{2+}$. To test the effect of $\mathrm{Zn}^{2+}$ as such, we added $\mathrm{ZnCl}_{2}$ (Sigma-Aldrich) to the extracellular solution containing tricine. The relationship between the total concentration of $\mathrm{Zn}^{2+}$ added to the extracellular solution $\left(\left[\mathrm{Zn}^{2+}\right]_{\text {added }}\right)$ and the concentration of free (nonchelated) $\mathrm{Zn}^{2+}\left(\left[\mathrm{Zn}^{2+}\right]_{\text {free }}\right.$ ) was calculated by the following equation (Fayyazuddin et al., 2000):

$$
\left[\mathrm{Zn}^{2+}\right]_{\text {free }}=\left[\mathrm{Zn}^{2+}\right]_{\mathrm{added}} / 200
$$

When measuring IPSCs in rod bipolar cells, we acquired baseline data for 5-10 min (with strychnine and TTX in the bath solution). We then changed to a $\mathrm{Mg}^{2+}$-free bath solution with $50 \mu \mathrm{M}$ NMDA and $200 \mu \mathrm{M}$ $\mathrm{D}$-serine and recorded for an additional $10 \mathrm{~min}$. To reduce membrane noise related to glutamate transporter activity in the rod bipolar cells from which we recorded, we added TBOA $(50 \mu \mathrm{M})$ to the intracellular solution (Veruki et al., 2006; Ichinose and Lukasiewicz, 2012). Drug solutions were either made up freshly for each experiment or were prepared from concentrated aliquots stored at $-20^{\circ} \mathrm{C}$.

General aspects of electrophysiological recording and data acquisition. Patch pipettes were pulled from thick-walled borosilicate glass (BF15086-10; Sutter Instrument) to obtain an open-tip resistance that ranged from 5 to $8 \mathrm{M} \Omega$ when filled with intracellular solution. Whole-cell voltage-clamp recordings were performed with an EPC9-dual, an EPC10-USB-dual, or an EPC10-triple amplifier (HEKA Elektronik) and controlled with Patchmaster software. In all experiments, rod bipolar cells and AII amacrine cells were held at a membrane potential of -60 $\mathrm{mV}$, and A17 amacrine cells were held at $-70 \mathrm{mV}$, unless otherwise indicated. For whole-cell recordings, series resistance $\left(R_{\mathrm{s}}\right)$ was monitored throughout the recording (for details, see Castilho et al., 2015). Cells with $R_{\mathrm{s}}>50 \mathrm{M} \Omega$ or with changes of $R_{\mathrm{s}}>30 \%$ were not included in the final material. For $\mathrm{Ca}^{2+}$ imaging experiments, $R_{\mathrm{s}}$ values $\leq 60 \mathrm{M} \Omega$ were accepted. The sampling interval was set between 50-200 $\mu \mathrm{s}$; and before sampling, signals were low-pass filtered (analog 3- and 4-pole Bessel filters in series) with a corner frequency $(-3 \mathrm{~dB})$ of $2-5 \mathrm{kHz}$. For stationary noise analysis (see below), the sampling interval was set to 500 $\mu \mathrm{s}$, and the corner frequency was set to $952.4 \mathrm{~Hz}$ (corresponding to a ratio of 2.1 between the sampling and corner frequencies). In addition, the filter characteristics were changed to Butterworth instead of Bessel.

Data analysis. Electrophysiological data were analyzed with Fitmaster (HEKA Elektronik; RRID:SCR_016233), IGOR Pro (WaveMetrics; RRID:SCR_000325), AxoGraph X (AxoGraph Scientific), Excel (Microsoft), and Prism (GraphPad Software; RRID:SCR_002798). The peak amplitude of NMDA-evoked currents was measured as the mean amplitude between two vertical cursors positioned close to the peak current response as identified by eye. Percent change was calculated using the following equation:

$$
\frac{\left(I_{N M D A, \text { control }}-I_{N M D A, t e s t}\right)}{I_{N M D A, \text { control }}} \times 100 \%
$$

with $I_{\mathrm{NMDA}}$, control as the average of three to five NMDA-evoked responses in the control condition (before application of antagonist) and $I_{\mathrm{NMDA}}$, test as the average of three to five NMDA-evoked current responses in the test condition (after application of antagonist in the bath solution for at least $5 \mathrm{~min}$ to ensure equilibration).

For analysis of responses evoked by voltage-ramp stimuli, we first performed a linear leak subtraction for each current response by fitting a line between $\sim-90 \mathrm{mV}$ and $-60 \mathrm{mV}$ and subtracting the corresponding function from the ramp current across the entire ramp voltage. The amplitude of the resulting current response was estimated as the average current in a window corresponding to the interval between 35 and 45 $\mathrm{mV}$. When comparing responses evoked in the control condition and in the presence of TBOA, percent change was calculated using the following equation:

$$
\frac{\left(I_{T B O A}-I_{\text {control }}\right)}{I_{\text {control }}} \times 100 \%
$$

with $I_{\text {control }}$ as the average of three to five ramp-evoked net current responses (after linear leak subtraction) in the control condition (in the window corresponding to the interval between 35 and $45 \mathrm{mV}$; before application of TBOA) and $I_{\mathrm{TBOA}}$ as the average of three to five rampevoked net current responses (after linear leak subtraction) in the test condition (after application of TBOA in the bath solution for at least 5 min to ensure equilibration).

When we examined membrane noise and its sensitivity to NMDA receptor channel antagonists, we measured noise as the variance of the membrane current recorded in the whole-cell voltage-clamp configuration. For each condition, current variance was calculated for epochs of $30 \mathrm{~s}$ duration (after digital low-pass filtering at $1 \mathrm{kHz} ;-3 \mathrm{~dB}$ ) and four such epochs were averaged. Stationary noise analysis (Neher and Stevens, 1977) was applied to current records without significant changes of steady-state channel activity over time and was performed as described by Mørkve et al. (2002). Current was sampled for 20 or 50 s epochs (sampling interval $500 \mu \mathrm{s}$ ), both in the control condition (with $1 \mathrm{~mm}$ $\mathrm{Mg}^{2+}$ ) and during application of NMDA (50 $\mu \mathrm{M}$; with $200 \mu \mathrm{M}$ D-serine) in $\mathrm{Mg}^{2+}$-free bath solution. For conditions with low channel open probability $(<0.1)$, the apparent unitary (single-channel) current can be calculated by dividing the variance by the mean steady-state agonist-evoked current. In all cases analyzed here, however, the data points spanned a larger range of values for open probability. Accordingly, current variance was plotted against mean steady-state current for the different epochs and the data points were fitted with the following parabolic function:

$$
\sigma^{2}(I)=i I-I^{2} / N+\sigma_{b}^{2}
$$

where $i$ is the apparent single-channel current, $I$ is the mean steady-state current, and $N$ is the number of available channels in the membrane $\left(\sigma_{\mathrm{b}}{ }^{2}\right.$, the variance of the background noise, had been subtracted out so the fitted curve was constrained to go through the origin).

MPE fluorescence microscopy and $\mathrm{Ca}^{2+}$ imaging. Red (from Alexa-594) and green (from OGB-1) fluorescence for structural and functional im- 
Table 1. Primary antibodies ${ }^{a}$

\begin{tabular}{lll}
\hline Antibody name & Immunogen & Source, catalog \#, RRID \\
\hline GluN2A & C-terminal fusion protein of rat NMDAR2A, amino acids 1253-1391 & Millipore, AB-1555P, AB_90770 \\
GluN2B & C-terminal fusion protein of rat NMDAR2B & Millipore, AB-1557P, AB_90772 \\
Cx36 & Synthetic peptide derived from C-terminal region of rat and mouse & Thermo Fisher Scientific, 37-4600, AB_2533320 \\
& $\quad$ Connexin36 protein &
\end{tabular}

${ }^{a}$ RRID, Research Resource Identifiers (for details, see the Resource Identification Portal: https://scicrunch.org/resources). The specificity of the rabbit antiserum against the NMDA receptor subunit GluN2A was demonstrated by the manufacturer. The antibody detects a single band of $\sim 180 \mathrm{kDa}$ in Western blots of rat brain membranes and has no reactivity to GluN2B or GluN2C. The same antibody has been used in a number of studies performed in the mammalian retina (e.g., Fletcher et al., 2000; Zhang and Diamond, 2009). The specificity of the rabbit antiserum against the NMDA receptor subunit GluN2B was demonstrated by the manufacturer. The antibody detects a single band of $\sim 180 \mathrm{kDa}$ in Western blots of rat brain membranes and has no reactivity to GluN2A or GluN2C. The same antibody has been used in a number of studies performed in the mammalian retina (e.g., Fletcher et al., 2000; Zhang and Diamond, 2009). The specificity of the mouse antibody against $\mathrm{X} 36$ has been characterized by the manufacturer. The antibody has been used in numerous studies throughout the CNS, including the retina, to detect Cx36 (Ciolofan et al., 2006 ; Hilgen et al., 2011 ; Meyer et al., 2016).

aging, respectively, were imaged with the Movable Objective Microscope equipped with a Ti:sapphire laser (Mai Tai DeepSee; SpectraPhysics) tuned to $810 \mathrm{~nm}$. For cellular morphology, image stacks were acquired as a series of optical slices (typically $1024 \times 1024$ pixels; 2 frames/slice) at focal plane intervals of $0.4 \mu \mathrm{m}$. For imaging intracellular $\mathrm{Ca}^{2+}$ dynamics in processes of AII and A17 amacrine cells, we sampled fluorescence at constant focal planes in frame-scan mode $(256 \times 256$ or $512 \times 512$ pixels) at intervals of $\sim 20 \mathrm{~s}$ with three channels for each frame. The first two channels corresponded to green fluorescence from OGB-1 and red fluorescence from Alexa-594. The third channel captured an infrared laser scanning gradient contrast image. MPE microscopy and image acquisition were controlled by ScanImage software (version 3.8.1) (Pologruto et al., 2003).

After establishing the whole-cell configuration, we waited 10-15 min for AII amacrines and $30 \mathrm{~min}$ for A17 amacrines before starting $\mathrm{Ca}^{2+}$ imaging to allow for maximal indicator loading. We first used MPE structural imaging of a cell to select a focal plane with a relatively large number of visible processes. Next, we acquired frame scans at the selected focal plane with an interframe interval of $20 \mathrm{~s}$. After acquiring baseline image data for $\sim 5 \mathrm{~min}$ (with TTX, strychnine, bicuculline, and CNQX in the bath solution), we changed to a $\mathrm{Mg}^{2+}$. free bath solution with 50 or $100 \mu \mathrm{M}$ NMDA and applied NMDA for 4-6 min. Image acquisition was performed continuously throughout the NMDA application and for up to $30 \mathrm{~min}$ after changing to a drug-free bath solution with normal $\mathrm{Mg}^{2}$. After $\mathrm{Ca}^{2+}$ imaging, a $Z$ stack that sampled as much as possible of the complete morphology of the cell was acquired, using the red fluorescence (Alexa-594). The images were sampled at a rate close to or higher than the ideal Nyquist rate (for details, see Zandt et al., 2017). For analysis of $\mathrm{Ca}^{2+}$ imaging data, the different channels of each frame were first deinterleaved for all frames in the series and compiled as separate time-series stacks in IGOR Pro. To compensate for drift and mechanical instabilities, the images in each stack (channel) were aligned along the virtual $z$ axis (here corresponding to time) using the IGOR Pro ImageRegistration operation as implemented in the SARFIA RegisterStack routines (Dorostkar et al., 2010). Frame-scan $\mathrm{Ca}^{2+}$ imaging data were analyzed by custom routines developed under IGOR Pro. Background fluorescence $\left(F_{\mathrm{b}}\right)$ was measured as the average signal from a rectangular area close to the regions of interest (but without contamination from dye spilled extracellularly when the whole-cell recording was established). The relative change in fluorescence related to a change in $\mathrm{Ca}^{2+}$ was calculated as the ratio of green fluorescence $(G)$ over red fluorescence $(R)$, and changes in $\mathrm{Ca}^{2+}$ were measured as the difference between $G / R$ for a given point in time and $G / R$ averaged for the baseline period, for simplicity referred to as $\Delta G / R$. Because the red fluorescence from Alexa-594 is considerably brighter than the green fluorescence from OGB-1, $\Delta G / R$ is considered a more robust measure of $\mathrm{Ca}^{2+}$ dynamics than $\Delta F / F$ (Yasuda et al., 2004) (e.g., in relation to movement artifacts which can be a problem with longer-lasting frame scanning as used here).

Cell injection, immunocytochemical labeling, and confocal microscopy. Visually targeted AII and A17 amacrine cells in retinal slices, visualized with a $60 \times$ water-immersion objective and Dodt gradient contrast on an Olympus BX51 WI microscope, were impaled with sharp microelectrodes filled with $5 \mathrm{~mm}$ Alexa-488 dissolved in $200 \mathrm{~mm}$ $\mathrm{KCl}$ (for details, see Hartveit et al., 2018). Following injection, slices were fixed at room temperature for $10 \mathrm{~min}$ in $4 \%$ PFA in $0.1 \mathrm{M}$ phosphate buffer. For details of the antibody labeling, see Hartveit et al. (2018). Primary antibodies used in the present study are listed in Table land have all been used before in retina and other CNS tissues (Fletcher et al., 2000; Ciolofan et al., 2006; Zhang and Diamond, 2009; Hilgen et al., 2011; Meyer et al., 2016). Secondary antibodies included goat anti-mouse and goat anti-rabbit coupled to AlexaFluor-555 or AlexaFluor-647 (Invitrogen; Thermo Fisher Scientific) and were used at a dilution of 1:500. The methods for confocal microscopy and image acquisition have previously been described in detail (Hartveit et al., 2018). Briefly, retinal slices were imaged on a TCS SP5 confocal microscope (Leica Microsystems) equipped with a $63 \times$ oilimmersion objective (HCX PL APO CS UV, 1.4 NA; Leica Microsystems). For fluorescence imaging, we used the following lasers and laser lines: Argon $488 \mathrm{~nm}$ (for Alexa-488 in the first channel), DPSS $561 \mathrm{~nm}$ (for Alexa-555 in the second channel), and HeNe $633 \mathrm{~nm}$ (for Alexa-647 in the third channel).

Image processing, deconvolution, and analysis. For the morphological $Z$ stacks sampled with MPE and confocal microscopy, Huygens Essential (version 14-16, 64 bit, Scientific Volume Imaging; RRID: SCR_014237) was used to digitally deconvolve each channel in the image stack to remove noise (effectively increasing the SNR) and decrease axial and lateral blurring (for details, see Zandt et al., 2017; Hartveit et al., 2018). We visually identified immunolabeled punctae that overlapped dye-filled processes of amacrine cells in the $X Y$ plane. Punctae with overlap in the $X Y$ plane were then verified by examining the overlap and separation in the $X Z$ and $Y Z$ planes to ensure that the apparent overlap was not caused by the lower axial ( $z$ axis) resolution. If, as in some cases, overlap in the $X Y$ plane was due to "smear" along the $z$ axis, a relatively large separation between the visually estimated center of mass (CM) of the immunolabeled punctum and that of the dye-filled process was discernible. These punctae were not included as overlapping. The procedures for quantitative analysis of dye-filled neurons and immunolabeled punctae have previously been described in detail (Hartveit et al., 2018).

Experimental design and statistical analysis. Data are presented as mean $\pm \operatorname{SEM}(n=$ number of cells) with ranges either displayed by individual data points in bar graphs or stated explicitly. A minimum of three cells were used per experimental group. Statistical analyses were performed using Student's two-tailed $t$ tests (paired, ratio or unpaired) as indicated or one-way ANOVA, followed by multiplecomparison tests (as indicated) to obtain adjusted $p$ values (Prism). Differences were considered statistically significant at the $p<0.05$ level. Exact $p$ values are given in figure legends or in the text. Unless otherwise noted, the current traces shown in the figures represent individual traces. The number of individual traces included in averaged current traces in the figures is stated for each case. For illustration purposes, most raw data records were either low-pass filtered $(-3 \mathrm{~dB}$; digital nonlagging Gaussian filter at $0.5-1 \mathrm{kHz}$ ) or smoothed by a binomial smoothing function (IGOR Pro) to emphasize the kinetics of the response. Together, we recorded from or filled $\sim 115$ AII amacrines, 83 A17 amacrines, and 18 rod bipolar cells. 

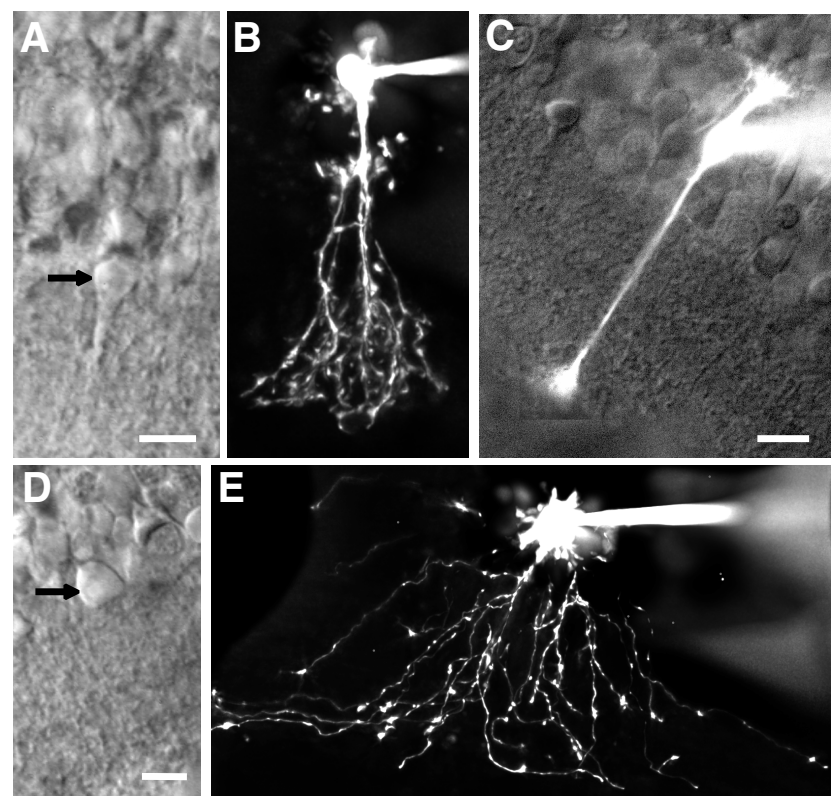

$\mathbf{F}$
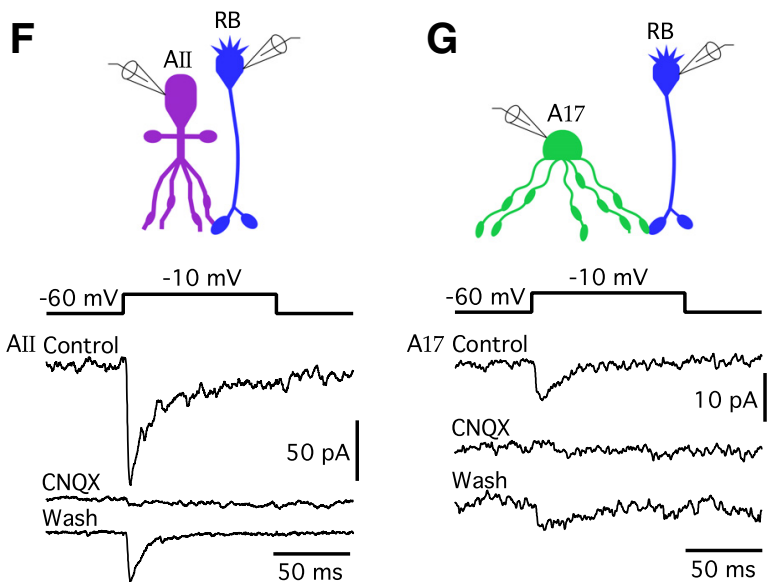

Figure 1. Identification of microcircuit with presynaptic rod bipolar cells and postsynaptic All and A17 amacrine cells in the rat retinal slice preparation. $A$, IR-DIC videomicrograph of a retinal slice with cell body (arrow) and apical dendrite of an All amacrine cell. Scale bar: $\boldsymbol{A}, \boldsymbol{B}, 10$ $\mu \mathrm{m}$. $\boldsymbol{B}$, Wide-field fluorescence image of All amacrine cell filled with Alexa-594 via patch pipette (MIP of image stack after deconvolution). C, Wide-field fluorescence image of rod bipolar cell filled with Alexa-594 via patch pipette (MIP of image stack after deconvolution) overlaid on IR-DIC videomicrograph of retinal slice. Scale bar, $10 \mu \mathrm{m}$. D, IR-DIC videomicrograph of a retinal slice with cell body (arrow) of an A17 amacrine cell. Scale bar: $\boldsymbol{D}, \boldsymbol{E}, 10 \mu \mathrm{m}$. $\boldsymbol{E}$, Wide-field fluorescence image of A17 amacrine cell filled with Alexa-594 via patch pipette (MIP of image stack after deconvolution). $\boldsymbol{F}, \mathbf{G}$, NMDA receptors do not contribute to synaptic input from rod bipolar cells to All $(\boldsymbol{F})$ or A17 (G) amacrine cells. $\boldsymbol{F}$, Schematic figure of experimental configuration with simultaneous dual whole-cell voltage-clamp recording of presynaptic rod bipolar cell (blue) and postsynaptic All amacrine cell (magenta) in rat retinal slice (top). Top, Voltage command applied to rod bipolar cell with depolarization $(100 \mathrm{~ms})$ from -60 to $-10 \mathrm{mV}$. Three bottom traces represent current measured in All amacrine cell in response to rod bipolar cell depolarization in the following conditions: during control (average of three traces), during application of the non-NMDA receptor antagonist CNQX (10 $\mu \mathrm{m}$; average of five traces), and after washout of CNQX (average of four traces). Note the transient inward current in response to depolarization of rod bipolar cell in control condition, complete block by CNQX, and partial recovery after washout of CNQX. In this and subsequent figures, the nominal concentration of $\mathrm{Mg}^{2+}$ in the extracellular solution was zero (unless otherwise indicated), and the bath also contained TTX (300 nM) to block voltage-gated $\mathrm{Na}^{+}$channels, bicuculline $(10 \mu \mathrm{m})$ to block $\mathrm{GABA}_{\mathrm{A}}$ receptors, strychnine $(1 \mu \mathrm{m})$ to block glycine receptors, and the NMDA receptor coagonist D-serine $(200 \mu \mathrm{M})$. G, Schematic figure of experimental configuration with simultaneous dual whole-cell voltage-clamp recording of presynaptic rod bipolar cell (blue) and postsynaptic A17 amacrine cell (green) in rat retinal slice (top). Top, Voltage command applied to rod bipolar cell with depolarization (100 ms) from -60 to $-10 \mathrm{mV}$. Three bottom traces represent

\section{Results}

Identification of AII and A17 amacrine cells and rod bipolar cells in retinal slices

The cellular elements and basic synaptic connectivity of the rod bipolar cell-AII-A17 microcircuit are illustrated in Figure 1. As reliable identification of the two types of amacrine cells, both with respect to each other and with respect to other types of amacrine cells, is important for the conclusions of this study, we emphasize the procedure followed for the visual targeting, recording, and identification of these cells in retinal slices. The primary targeting criterion was the shape and location of the cell bodies at the border between the inner nuclear layer and the inner plexiform layer (Fig. 1A,D). The AII amacrine cell is a bistratified, narrow-field amacrine cell with a cell body that spans the border between the inner nuclear and the inner plexiform layer, and a thick apical dendrite that tapers as it descends into the inner plexiform layer (Fig. 1B). In contrast, the A17 amacrine cell is a diffuse, wide-field amacrine cell with a dome-shaped cell body and long, thin processes that carry distinct varicosities and terminate near the ganglion cell layer of the retina (Fig. 1E). For dual recordings between rod bipolar cells and either AII or A17 amacrines, rod bipolar cells were targeted based on the location of a cell body at the distal end of the inner nuclear layer, close to the outer plexiform layer. For unequivocal identification, all recorded cells were visualized with fluorescence microscopy following the recording. For AII amacrine cells, this allowed us to verify their narrow-field bistratified morphology (Fig. 1B) and for A17 amacrine cells we could identify their long, thin processes that carry varicosities and terminate near the ganglion cell layer of the retina (Fig. 1E). Rod bipolar cells have a single long axon that terminates with a number of large axon terminals in the proximal part of the inner plexiform close to the ganglion cell layer (Fig. $1 C)$.

NMDA receptors do not contribute to EPSCs in AII and A17 amacrine cells evoked by depolarization of rod bipolar cells There is evidence for the expression of NMDA receptors by both AII and A17 amacrine cells (Hartveit and Veruki, 1997; Zhou and Dacheux, 2004; Kothmann et al., 2012; Zhou et al., 2016), but it is less clear whether the receptors contribute to mediating glutamatergic synaptic input from rod bipolar cells. To investigate the potential involvement of NMDA receptors, we performed simultaneous dual patch-clamp recordings between pairs of rod bipolar cells and AII amacrine cells and between pairs of rod bipolar cells and A17 amacrine cells (Fig. $1 F, G$ ). For both sets of recordings, the bath solution was changed to a $\mathrm{Mg}^{2+}$-free solution (including $200 \mu \mathrm{M}$ of the NMDA receptor coagonist D-serine), at least $10 \mathrm{~min}$ before breaking into the cells, to eliminate the voltage-dependent $\mathrm{Mg}^{2+}$ block of NMDA receptors.

In dual recordings from pairs of rod bipolar cells and AII amacrine cells, with both cells in the whole-cell voltage-clamp configuration $\left(V_{\text {hold }}=-60 \mathrm{mV}\right.$ for both cells $)$, we first verified that the cells were synaptically connected by applying a depolarizing voltage step to the rod bipolar cell (to $-10 \mathrm{mV}$ ). In the

\section{$\leftarrow$}

current measured in A17 amacrine cell in response to rod bipolar cell depolarization in the following conditions: during control (average of four traces), during application of the nonNMDA receptor antagonist CNQX (10 $\mu$ m; average of four traces), and after washout of CNQX (average of two traces). Note the transient inward current in response to depolarization of rod bipolar cell in control condition, complete block by CNQX, and partial recovery after washout of CNQX. 
presence of a synaptic connection, the depolarization evoked a large transient inward current in the AII amacrine cell (Fig. $1 F$ ), corresponding to an EPSC (Singer and Diamond, 2003; Veruki et al., 2003; Trexler et al., 2005). Next, the bath solution was exchanged to include $10 \mu \mathrm{M}$ CNQX to block non-NMDA receptors and potentially reveal a non-NMDA receptor-independent component of the EPSC. In all cases, however, application of CNQX completely blocked the rod bipolar cell-evoked EPSC in AII amacrine cells (Fig. $1 F ; n=6$ cell pairs). In the control condition, the average peak amplitude (relative to baseline) was $116 \pm 20 \mathrm{pA}$ and in the presence of CNQX the average was $3.2 \pm 1.0 \mathrm{pA}$. The current in the presence of CNQX was indistinguishable from baseline membrane noise. For three rod bipolar-AII cell pairs, we observed not only a block of the EPSC in the presence of CNQX, but also a partial recovery of the EPSC after washout of CNQX (Fig. $1 F$ ), suggesting that rundown of transmitter release was not the reason for the lack of response.

We next performed the same type of experiment for synaptically connected pairs of rod bipolar cells and A17 amacrine cells. In contrast to the synapse between a rod bipolar cell and an AII amacrine cell, depolarization of a rod bipolar cell (to $-10 \mathrm{mV}$ ) evoked a much smaller EPSC in an A17 amacrine cell (Fig. 1G). For seven synaptically connected cell pairs, the average peak amplitude of the depolarization-evoked EPSC in the control condition was $8.2 \pm 1.2 \mathrm{pA}$ (range 5.3-15 pA). In the presence of $\mathrm{CNQX}$, the average peak response in the same A17 amacrines was $2.1 \pm 0.5 \mathrm{pA}$ (range $0.2-3.8 \mathrm{pA}$ ). Similar to AII amacrine cells, the current in the presence of CNQX was indistinguishable from the baseline noise. After washout of CNQX, recovery (partial) was observed in three of the paired recordings (Fig. $1 G$ ). Together, our results suggest that NMDA receptors do not contribute directly to synaptic transmission between rod bipolar cells and either A17 or AII amacrine cells. In the case of the AII, these results corroborate earlier studies by Singer and Diamond (2003) and Trexler et al. (2005).

Whereas A17 amacrines receive glutamatergic input only from rod bipolar cells, AII amacrines are likely to receive glutamatergic input from at least some types of OFF-cone bipolar cells (Veruki et al., 2003; Graydon et al., 2018). However, it is unlikely that NMDA receptors are expressed at the OFF-cone bipolar cell to AII synapse. First, EM immunolabeling for the GluN1 subunit suggests that only one of the two profiles postsynaptic to OFFcone bipolar cell ribbons (presumably one ganglion cell and one amacrine cell) expresses NMDA receptors (Fletcher et al., 2000). This profile most likely belongs to a ganglion cell, as a synaptic NMDA component has consistently been identified in OFFganglion cells (e.g., Manookin et al., 2010; Buldyrev et al., 2012; Stafford et al., 2014). In addition, no NMDA component was revealed in the synaptic input to AII amacrines from Type 2 OFFcone bipolar cells (that mediate the predominant input from OFF-cone bipolar cells to AIIs) (Graydon et al., 2018). For these reasons, we did not further test for synaptic NMDA receptors at OFF-cone bipolar cell to AII synapses in this study.

\section{Ambient glutamate can activate NMDA receptors on both AII and $\mathrm{A} 17$ amacrine cells}

That NMDA receptors are expressed by AII and A17 amacrines, but not activated directly after neurotransmitter release from presynaptic rod bipolar cells, suggests that the receptors are located outside the postsynaptic density of the dyad synapses, at an extrasynaptic location. In the present context, extrasynaptic could mean perisynaptic (i.e., outside but in the immediate vicinity of the synapse) or further away. In a previous study, our lab- oratory provided physiological evidence that few, if any, NMDA receptors are located at the cell bodies of AII and A17 amacrine cells, and therefore are unlikely to be responsible for the responses evoked in either cell type by application of NMDA (Zhou et al., 2016). Regardless of the exact location of the NMDA receptors, we can propose two different mechanisms for their potential activation under physiological conditions. One mechanism involves direct spillover of synaptically released glutamate, and the other mechanism involves activation by ambient glutamate. With respect to the first mechanism, there is evidence that glutamate spillover at the rod bipolar cell axon terminal can activate glutamate transporters on the same and neighboring axon terminals (Veruki et al., 2006; Wersinger et al., 2006). Depending on their exact location, this suggests that NMDA receptors on AII and A17 amacrine cells under certain conditions could be activated by spillover of glutamate from rod bipolar cells after synaptic release. With respect to the second mechanism, there is evidence that the concentration of ambient glutamate (of neuronal and/or glial origin) in the extracellular environment of the CNS is sufficiently high to activate different extrasynaptic receptors (Chen and Diamond, 2002; Cavelier et al., 2005; Tzingounis and Wadiche, 2007).

If activation of NMDA receptors contributes to membrane noise under baseline conditions, it should be possible to block their contribution by blocking the receptors. To test this hypothesis, we recorded membrane noise for $\sim 10 \mathrm{~min}$ before adding the NMDA receptor antagonist CPP $(20 \mu \mathrm{M})$ to the bath solution. The bath solution was $\mathrm{Mg}^{2+}$-free and contained CNQX, bicuculline, strychnine, and TTX (to block non-NMDA, GABA , and glycine receptors, and voltage-gated $\mathrm{Na}^{+}$channels, respectively), as well as D-serine. We analyzed the membrane noise by calculating the variance of the membrane current recorded during a 2 min period in the control condition and a $2 \mathrm{~min}$ period in the presence of CPP. For the AII amacrine cell illustrated in Figure $2 A$, the addition of CPP markedly decreased the membrane noise, from an average variance of $31 \mathrm{pA}^{2}$ in the control condition to 8.0 $\mathrm{pA}^{2}$ in the presence of CPP. This suggested that gating of NMDA receptor channels contributed substantially to membrane noise in our baseline condition. That the membrane noise was suppressed by the competitive antagonist CPP also suggests that the channel gating was driven by the presence of an endogenous agonist of the NMDA receptor, which is likely to be glutamate. For AII amacrine cells tested in this way, the average variance in the control condition was $20.0 \pm 3.9 \mathrm{pA}^{2}$; and in the presence of $\mathrm{CPP}$, it was $7.3 \pm 1.2 \mathrm{pA}^{2}(p=0.0395$, paired $t$ test; $n=4$ cells $)$, corresponding to an average reduction of $60 \pm 8 \%$ (Fig. $2 A$ ).

Similar results were seen for A17 amacrine cells tested the same way. For the cell illustrated in Figure $2 B$, the membrane noise was reduced from $4.4 \mathrm{pA}^{2}$ in control to $3.1 \mathrm{pA}^{2}$ in the presence of CPP. For all A17 amacrines tested, the membrane noise was reduced from $6.3 \pm 0.9 \mathrm{pA}^{2}$ in control to $3.2 \pm 0.2 \mathrm{pA}^{2}$ in the presence of CPP ( $p=0.0169$, paired $t$ test; $n=6$ cells $)$, corresponding to an average reduction of $46 \pm 6 \%$ (Fig. $2 B$ ). These results suggest that, for both AII and A17 amacrine cells, ambient levels of glutamate are sufficiently high to gate NMDA receptor channels.

We next examined whether the increased activity of glutamate transporters at a more physiological temperature would reduce the level of ambient glutamate and/or prevent spillover of synaptic glutamate (Wadiche et al., 1995; Asztely et al., 1997; Rauen et al., 1998) and thus reduce or eliminate the observed NMDA receptor-mediated membrane noise. When we repeated these experiments for AII amacrine cells at $32^{\circ} \mathrm{C}$, the average variance in 
A
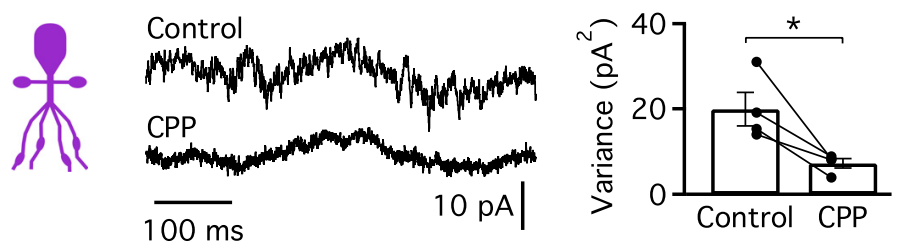

B

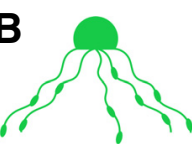

Control

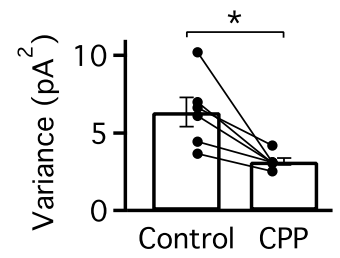

C

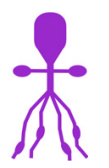

Control $\left(32^{\circ} \mathrm{C}\right)$
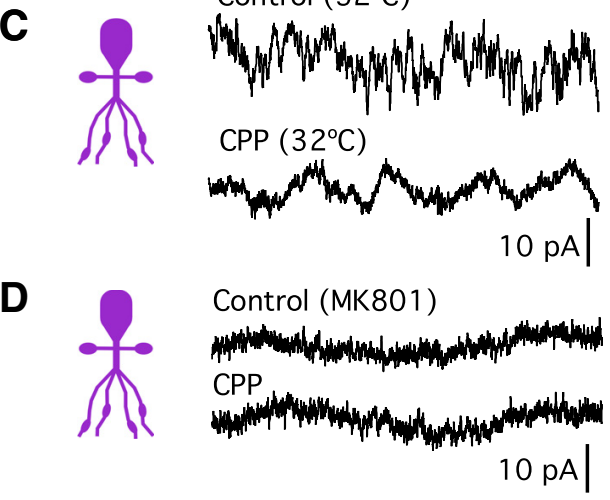

E

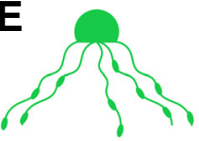

Control (MK801)

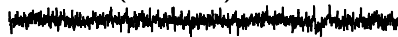

CPP

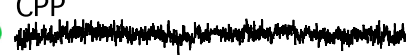

$10 \mathrm{pA}$

$\mathbf{F}$
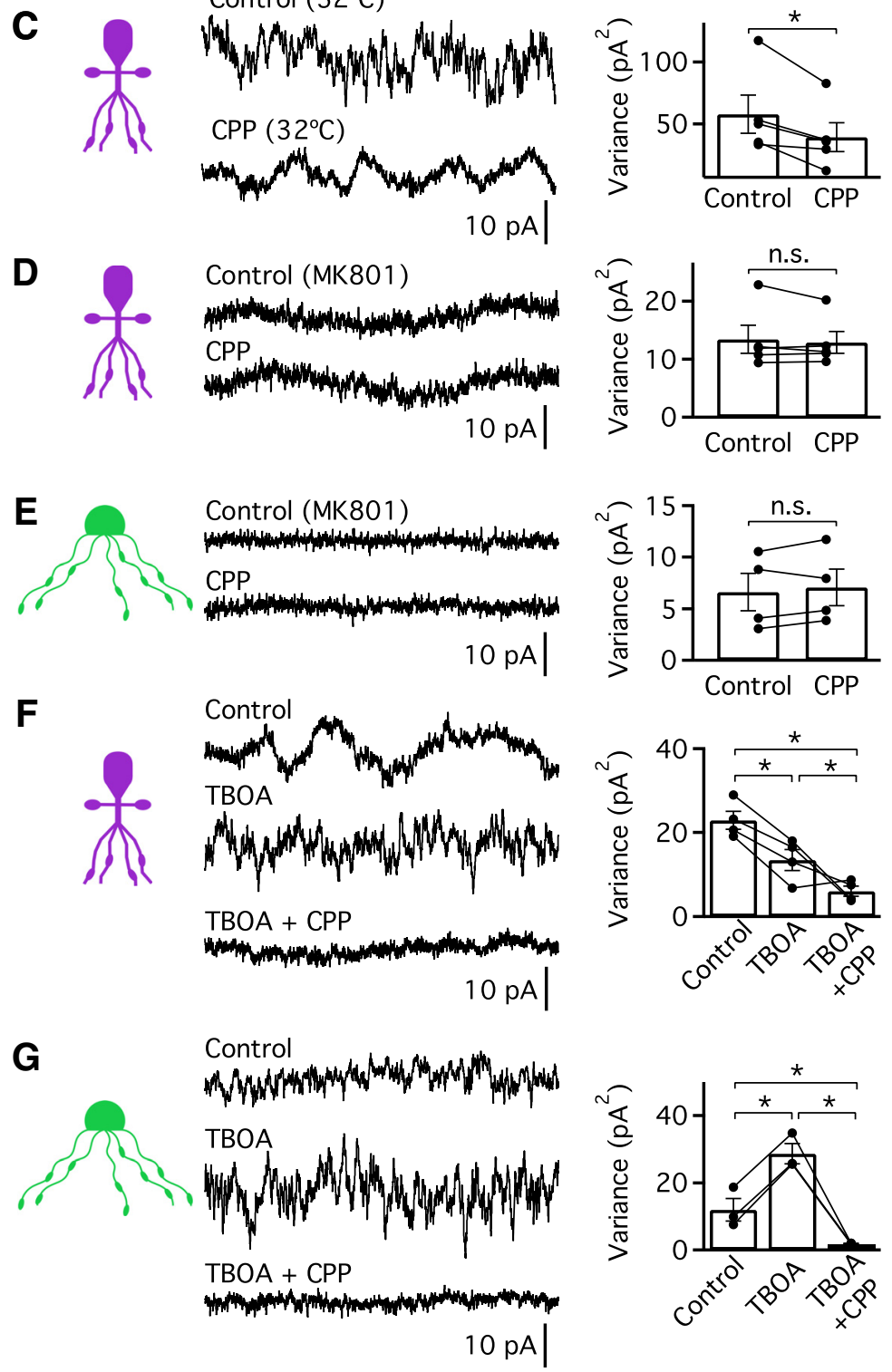

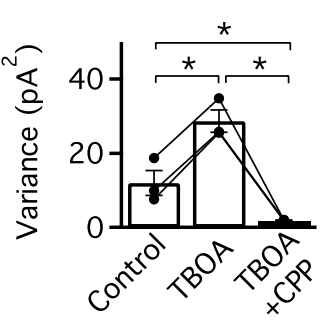

the control condition was $57.7 \pm 15.4$ $\mathrm{pA}^{2}$; and in the presence of CPP, it was $39.3 \pm 11.7 \mathrm{pA}^{2}(p=0.0223$, paired $t$ test; $n=5$ cells; Fig. $2 C$ ), corresponding to an average reduction of $33 \pm 9 \%$. This sug-

current recorded from an A17 amacrine cell in whole-cell voltage clamp in control condition (top) and during application of CPP $(20 \mu \mathrm{M})$ in the extracellular solution to block NMDA receptors (bottom). Note the reduction of membrane current noise in the presence of CPP, suggesting activation of NMDA receptors by ambient glutamate in the control condition. Bar graphs (right) represent membrane current noise measured as variance in A17 amacrine cells ( $n=6$ cells) in control and in the presence of CPP. C, Continuous current recorded from an All amacrine cell in whole-cell voltage clamp at $32^{\circ} \mathrm{C}$ in control condition (top) and during application of CPP $(20 \mu \mathrm{M})$ in the extracellular solution to block NMDA receptors (bottom). Note the reduction of membrane current noise in the presence of CPP, suggesting activation of NMDA receptors by ambient glutamate in the control condition at $32^{\circ} \mathrm{C}$. Bar graphs (right) represent membrane current noise measured as variance in All amacrine cells ( $n=5$ cells) at $32^{\circ} \mathrm{C}$ in control and in the presence of CPP. $\boldsymbol{D}, \boldsymbol{E}$, No effect of CPP on membrane current noise when the NMDA receptors are blocked by the open-channel blocker MK-801 (2 mM) in the intracellular solution. D, Continuous current recorded from an All amacrine cell in whole-cell voltage clamp in control condition (top) and during application of CPP $(20 \mu \mathrm{M})$ in the extracellular solution to block NMDA receptors (bottom). Note that including MK-801 intracellularly blocks the effect of CPP on membrane current noise, suggesting that the noise is generated by activation by ambient glutamate of NMDA receptors in the All amacrine cell itself. Bar graphs (right) represent membrane current noise measured as variance in All amacrine cells ( $n=5$ cells; MK-801 in the intracellular solution) in control and in the presence of (PP. $\boldsymbol{E}$, Continuous current recorded from an A17 amacrine cell in whole-cell voltage clamp in control condition (top) and during application of CPP $(20 \mu \mathrm{m})$ in the extracellular solution to block NMDA receptors (bottom). Note that including MK-801 intracellularly blocks the effect of CPP on membrane current noise, suggesting that the noise is generated by activation by ambient glutamate of NMDA receptors in the A17 amacrine cell itself. Bar graphs (right) represent membrane current noise measured as variance in A17 amacrine cells ( $n=4$ cells; MK-801 in the intracellular solution) in control and in the presence of CPP. $F, G$, Effect of blocking glutamate uptake on membrane noise. $\boldsymbol{F}$, Continuous current recorded from an All amacrine cell in whole-cell voltage clamp in control condition (top), during application of the glutamate transporter blocker TBOA (50 $\mu$ m; middle), and during combined application of TBOA and CPP (20 $\mu \mathrm{m}$; bottom). Note that membrane current noise is reduced by TBOA and further reduced by CPP. Bar graphs (right) represent membrane current noise measured as variance in All amacrine cells ( $n=4$ cells) in control (without TBOA and (PP; left bar), in the presence of TBOA, and in the presence of TBOA + CPP. G, Continuous current recorded from an A17 amacrine cell in whole-cell voltage clamp in control condition (top), during application of the glutamate transporter blocker TBOA (50 $\mu \mathrm{m}$; middle), and during combined application of TBOA and CPP (20 $\mu$ m; bottom). Note that membrane current noise is increased by TBOA and reduced by (PP. Bar graphs (right) represent membrane current noise measured as variance in $\mathrm{A} 17$ amacrine cells ( $n=3$ cells) in control, in the presence of TBOA, and in the presence of TBOA + CPP.

Figure 2. Activation of NMDA receptors by ambient glutamate generates membrane current noise in All and A17 amacrine cells. $\boldsymbol{A}$, Continuous current recorded from an All amacrine cell in whole-cell voltage clamp in control condition (top) and during application of CPP (20 $\mu \mathrm{M})$ in the extracellular bath to block NMDA receptors (bottom). Note the reduction of membrane current noise in the presence of CPP, suggesting activation of NMDA receptors by ambient glutamate in the control condition. Here and later, the identity of the cell from which the recording was performed is indicated by the schematic (left), with color and shape as in Figure 1. Bar graphs (right) represent membrane current noise measured as variance (here and later, bars represent mean \pm SEM) in All amacrine cells ( $n=4$ cells) in control (without CPP; left bar) and in the presence of CPP (right bar). For each cell (here and below), current variance was averaged over $2 \mathrm{~min}$. Here and later, data points for the same cell are connected by lines. Statistical comparisons between averages: n.s., No significant difference $(p>0.05)$. ${ }^{*} p<0.05$. $\boldsymbol{B}$, Continuous 
gested that, even at more physiologically relevant temperatures, with enhanced glutamate transporter activity, the level of ambient glutamate is sufficiently high to activate NMDA receptors.

The reduction of membrane noise in AII and A17 amacrines by CPP does not demonstrate conclusively that the NMDA receptor channels are located on these amacrine cells, as the reduction of noise could be due to transsynaptic effects. To explore this possibility, we performed experiments identical to those above but included the NMDA receptor antagonist MK-801 in the intracellular pipette solution. MK-801 acts as an open-channel blocker and can also block NMDA receptors from the intracellular side (Wong et al., 1986; Huettner and Bean, 1988). If intracellularly applied MK-801 reduces the effect of extracellularly applied CPP on the membrane noise, this would verify that the membrane noise must include gating of NMDA receptor channels on the AII and A17 amacrine cells themselves, and cannot be explained by gating of NMDA receptors exclusively located elsewhere in the network of neurons. For AII amacrine cells with 2 $\mathrm{mM} \mathrm{MK}-801$ in the recording pipette, the average variance was $13.4 \pm 2.4 \mathrm{pA}^{2}$ in the control condition, not significantly different from $12.9 \pm 1.9 \mathrm{pA}^{2}$ in the presence of CPP $(p=0.41$, paired $t$ test; $n=5$ cells; Fig. 2D). For A17 amacrine cells (with $2 \mathrm{~mm}$ MK-801 in the recording pipette), the average control variance was $6.6 \pm 1.8 \mathrm{pA}^{2}$, not significantly different from $7.1 \pm 1.8 \mathrm{pA}^{2}$ in the presence of CPP ( $p=0.385$, paired $t$ test; $n=4$ cells; Fig. $2 E)$. These results suggested that the NMDA receptor-mediated membrane noise observed in both AII and A17 amacrine cells, activated by ambient glutamate, is generated predominantly (even exclusively) by receptors located in the membrane of the recorded cells themselves and does not depend on potential transsynaptic effects.

\section{Increasing glutamate spillover can increase activation of NMDA receptors on AII and A17 amacrine cells}

In the retina (Rauen et al., 1998), like elsewhere in the CNS (for review, see Danbolt, 2001), the concentration of glutamate in different extracellular environments is a result of the balance between release, synaptic and nonsynaptic from neurons and potentially from glial cells, and uptake, primarily into glial cells, but also into neurons. We therefore hypothesized that pharmacologically blocking uptake mediated by glutamate transporters in glial cells and neurons could increase glutamate spillover and ambient glutamate and subsequently the level of activation of NMDA receptors on AII and A17 amacrine cells. To investigate this, we performed experiments where we used the specific, but nonselective, nontransported glutamate transporter blocker TBOA (Shimamoto et al., 1998) to increase extracellular glutamate.

In the first set of experiments, we examined whether application of TBOA $(50 \mu \mathrm{M})$ increased membrane noise, measured as the variance of the membrane current recorded in whole-cell voltage clamp (see above), and whether a TBOA-evoked increase was mediated by activation of NMDA receptors. For the AII amacrine cell illustrated in Figure $2 F$, however, the effect of TBOA was opposite of that hypothesized. The total current variance decreased from $23 \mathrm{pA}^{2}$ in the baseline condition to $17 \mathrm{pA}^{2}$ in the presence of TBOA. As in the experiments presented above, nonNMDA receptors, $\mathrm{GABA}_{\mathrm{A}}$ receptors, glycine receptors, and voltage-gated $\mathrm{Na}^{+}$channels were blocked pharmacologically and D-serine was added to the bath solution. When we added CPP (20 $\mu \mathrm{M})$ to block NMDA receptors, in the maintained presence of TBOA, the membrane noise was further reduced to a level of 8.7 $\mathrm{pA}^{2}$. For all AII amacrine cells tested in this way, adding TBOA decreased the membrane noise from $22.9 \pm 2.2 \mathrm{pA}^{2}$ to $13.5 \pm 2.5$
$\mathrm{pA}^{2}(p=0.03$, adjusted $p$ value, one-way ANOVA, followed by Holm-Sidak's multiple-comparisons test) and adding CPP further reduced the noise to $6.1 \pm 1.2 \mathrm{pA}^{2}(p=0.043$, adjusted $p$ value, one-way ANOVA, followed by Holm-Sidak's multiplecomparisons test; $n=4$ cells; Fig. $2 F$ ). The reduction of current variance by $\mathrm{CPP}$ suggested that NMDA receptor channel gating contributed to the membrane noise both in the baseline condition and in the presence of TBOA, which is further investigated below.

When A17 amacrine cells were tested in the same way with TBOA $(50 \mu \mathrm{M})$, the effect on membrane noise was very different from AII amacrines and consistent with our original hypothesis. For the A17 illustrated in Figure 2G, the membrane noise increased from $9.8 \mathrm{pA}^{2}$ in the baseline condition to $26 \mathrm{pA}^{2}$ in the presence of TBOA. When we added CPP to block NMDA receptors (in the maintained presence of TBOA), the membrane noise was reduced to $2.0 \mathrm{pA}^{2}$. For A17 amacrine cells tested in this way, adding TBOA increased the membrane noise from $12.0 \pm 3.4$ $\mathrm{pA}^{2}$ to $28.7 \pm 3.0 \mathrm{pA}^{2}(p=0.006$, adjusted $p$ value, one-way ANOVA, followed by Holm-Sidak's multiple-comparisons test) and adding CPP reduced the noise to $1.89 \pm 0.06 \mathrm{pA}^{2}(p=0.002$, adjusted $p$ value, one-way ANOVA, followed by Holm-Sidak's multiple-comparisons test; $n=3$ cells; Fig. $2 G$ ). These results suggested that, when glutamate transport was blocked with TBOA, increased extracellular glutamate enhanced the activation and gating of NMDA receptors on A17 amacrines, leading to an increase of membrane noise.

The reduced membrane noise of AII amacrine cells in the presence of TBOA was surprising. Closer inspection of the raw data, however, suggested that the effect of TBOA was more subtle than indicated by the overall reduction of current variance. As can be seen by the current traces illustrated in Figure $2 F$, TBOA did strongly reduce the low-frequency noise, but this was accompanied by an increase in higher-frequency noise. This higherfrequency noise was virtually eliminated following addition of $\mathrm{CPP}$, suggesting that it corresponded to NMDA receptor channel gating. We explored this by analyzing the spectral density of the current noise in the same four AII amacrine cells (Fig. $2 F$ ), both in control and in the presence of TBOA. We found that TBOA reduced the spectral density of frequencies $\sim<10 \mathrm{~Hz}$ but increased the spectral density of frequencies $\sim>10 \mathrm{~Hz}$ (Fig. $3 A$ ). To quantify this result, we measured the spectral density at $3.9 \mathrm{~Hz}$ and $39 \mathrm{~Hz}$ for each cell in both control and TBOA. Both the observed decrease (at $3.9 \mathrm{~Hz}$ ) and the observed increase (at 39 $\mathrm{Hz}$ ) of the spectral density was statistically significant $(p=0.020$ and $p=0.021$, respectively, ratio $t$ test, two-tailed; Fig. $3 B, C$ ). At this time, we cannot explain the cellular or molecular mechanisms that result in the reduction of variance of membrane noise in AII amacrines exposed to TBOA, but they may involve transsynaptic effects and transmission through electrical synapses (Veruki and Hartveit, 2002a,b). Regardless of any accompanying changes in membrane noise, we decided to investigate directly whether blocking glutamate uptake could evoke an increase in NMDA receptor-mediated current in AII amacrine cells.

The following experiments were performed with normal $\mathrm{Mg}^{2+}$ in the extracellular solution. To alleviate the $\mathrm{Mg}^{2+}$ dependent voltage block of NMDA receptor channels, we applied voltage ramps (from 50 to $-90 \mathrm{mV}$ at $200 \mathrm{mV} / \mathrm{s}$ ) and measured the average current in a window between 35 and $45 \mathrm{mV}$ of the $I-V$ curve obtained after subtracting a linear leak component calculated by fitting a straight line to the current measured between -90 and $-60 \mathrm{mV}$ (see Materials and Methods). To block depolarization-evoked activation of voltage-gated $\mathrm{K}^{+}$channels 
A

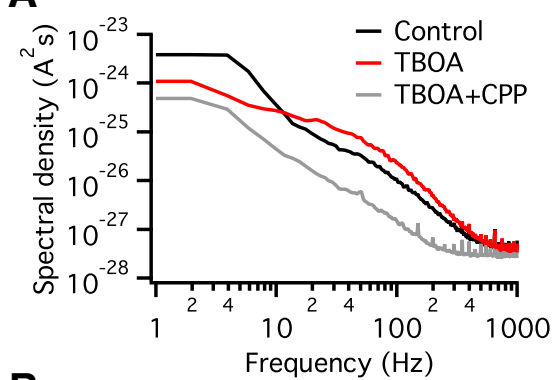

B

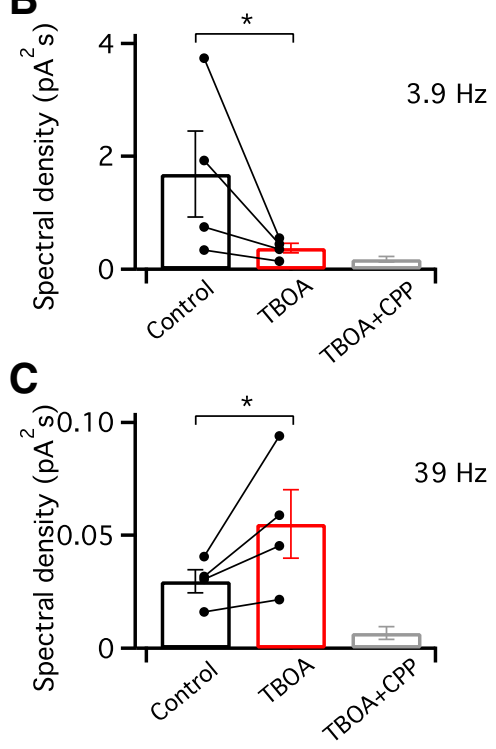

Figure 3. Frequency-dependent effect of TBOA on membrane noise in All amacrine cells. $\boldsymbol{A}$, Power density spectra obtained from the current noise in an All in the control condition (black line), during application of TBOA (50 $\mu$; red line), and during combined application of TBOA $(50 \mu \mathrm{M})+\mathrm{CPP}(20 \mu \mathrm{m}$; gray line). Note the crossing of the control and TBOA spectra at $\sim 10 \mathrm{~Hz}$. $B$, Spectral density measured at $3.9 \mathrm{~Hz}$ for All amacrine cells $(n=4)$ in control (without TBOA and (PP; left bar), in the presence of TBOA and in the presence of TBOA+ CPP. Here and in $C$, the data are from the same cells as illustrated in Figure 2F. C, Spectral density measured at $39 \mathrm{~Hz}$ in control (without TBOA and (PP; left bar), in the presence of TBOA and in the presence of TBOA+CPP. Statistical comparisons between averages: ${ }^{*} p<0.05$.

that would interfere with the measurements, the pipette solution contained $\mathrm{Cs}^{+}$and TEA (see Materials and Methods). In addition, the extracellular solution contained TEA (20 mM) and 3,4DAP $(0.1 \mathrm{mM})$ to block voltage-gated $\mathrm{K}^{+}$channels faster and more effectively.

If application of TBOA evokes an increased activation of NMDA receptors, it should be revealed as an increase of the current measured in the averaging window between 35 and $45 \mathrm{mV}$. For the AII amacrine cell illustrated in Figure $4 A$, we applied voltage ramps approximately every $4 \mathrm{~s}$. During the first period of $\sim 5 \mathrm{~min}$, the current response (measured in the averaging window) decreased markedly, corresponding to a gradually increasing block of voltage-gated $\mathrm{K}^{+}$currents mediated by diffusion into the cell of $\mathrm{Cs}^{+}$and TEA from the pipette solution. After this period, we switched to the extracellular solution with TEA and 3,4-DAP and observed that the current response continued to decrease, reflecting increased block of voltage-gated $\mathrm{K}^{+}$channels, before stabilizing at a relatively constant plateau (Fig. 4A). When TBOA $(50 \mu \mathrm{M})$ was added to the bath solution, the current response increased by $\sim 60 \mathrm{pA}$ (from 30 to $90 \mathrm{pA}$; Fig. $4 A$ ). When TBOA was washed out, the current decreased approximately to the level before TBOA was applied. For quantitative analysis, we used this more stable period as the control condition. The $I-V$ curves illustrated in Figure $4 B$ correspond to leak-subtracted currents evoked by voltage ramps applied at two time points during the recording in Figure $4 A$ : during application of TBOA (1; "TBOA") and after washout of TBOA (2; "Control"). The difference between the two $I-V$ curves corresponds to the $I-V$ curve of the net current evoked by TBOA (Fig. 4C) and displays a voltage dependence similar to that expected for a current mediated by NMDA receptors. For AII amacrine cells tested in this way, TBOA increased the current from a control level of $18.3 \pm 3.8 \mathrm{pA}$ to $54.7 \pm 8.8 \mathrm{pA}(p=0.0033$, paired $t$ test; $n=6$ cells; Fig. $4 D)$.

If this TBOA-evoked current was mediated by activation of NMDA receptors, it should be blocked by CPP. For the cell illustrated in Figure $4 E$, the response stabilized to a relatively constant level after $\sim 10 \mathrm{~min}$. When we applied TBOA $(50 \mu \mathrm{M})$ and CPP $(20 \mu \mathrm{M})$ together, there was no obvious change in the current response (Fig. 4E). Following washout of CPP, TBOA applied alone evoked an increase in response of $\sim 45 \mathrm{pA}$. This was followed by a slow reversal when TBOA was washed out at the end of the recording period (Fig. $4 E$ ). For AII amacrine cells tested in this way, the response increased from an average of $41.1 \pm 6.6 \mathrm{pA}$ in the presence of TBOA and CPP to an average of $80 \pm 20 \mathrm{pA}$ in the presence of TBOA alone after washout of CPP $(p=0.0263$, adjusted $p$ value, one-way ANOVA, followed by Holm-Sidak's multiple-comparisons test; $n=6$ cells; Fig. $4 F$ ). These results suggest that CPP can block the effect of TBOA on the voltage ramp-evoked current, supporting the hypothesis that the increase of current evoked by TBOA is mediated by activation of NMDA receptors.

Whereas the addition of TEA and 3,4-DAP to the extracellular solution was useful in the sense that it led to a faster and more effective block of voltage-gated $\mathrm{K}^{+}$currents (compared with $\mathrm{Cs}^{+}$ and TEA only in the pipette solution), it could overestimate the effect of TBOA because block of voltage-gated $\mathrm{K}^{+}$channels in bipolar cells could lead to depolarization, increased excitability, and increased release of glutamate. Indeed, when we recorded from AII amacrine cells and switched to a bath solution with TEA and 3,4-DAP, we observed a strong increase in bursting synaptic input occurring at a frequency of $\sim 0.5 \mathrm{~Hz}$ (data not shown). Although increased release of glutamate does not invalidate the observed effect of TBOA as such, we performed control experiments where we examined the effect of TBOA using our standard bath solution without TEA and 3,4-DAP.

For the AII amacrine cell illustrated in Figure 4G, the voltage ramp-evoked response decreased slowly in the control condition and became relatively stable after $\sim 15 \mathrm{~min}$. When we added a combination of TBOA $(50 \mu \mathrm{M})$ and CPP $(20 \mu \mathrm{M})$ to the bath solution, there was no change in the response (Fig. $4 G$ ). At $\sim 25$ min, CPP was washed out and TBOA was applied alone. This led to a clear increase of the response that slowly decreased back to the baseline when TBOA was washed out (Fig. 4G). We tested a total of four AII amacrine cells in this condition (coapplication of TBOA and CPP followed by application of TBOA alone) and two cells with the opposite order of application (i.e., first TBOA alone, followed by coapplication of TBOA and CPP). The average current during coapplication of TBOA and CPP was $130.7 \pm 7.8 \mathrm{pA}$, compared with an average current of $182 \pm 22 \mathrm{pA}$ when TBOA was applied alone $(p=0.0215$, adjusted $p$ value, one-way ANOVA, followed by Holm-Sidak's multiple-comparisons test; $n=6$ cells; Fig. $4 H$ ).

The above results suggested that blocking glutamate transporters with TBOA can increase activation of NMDA receptors, both during baseline conditions of release and when release pre- 

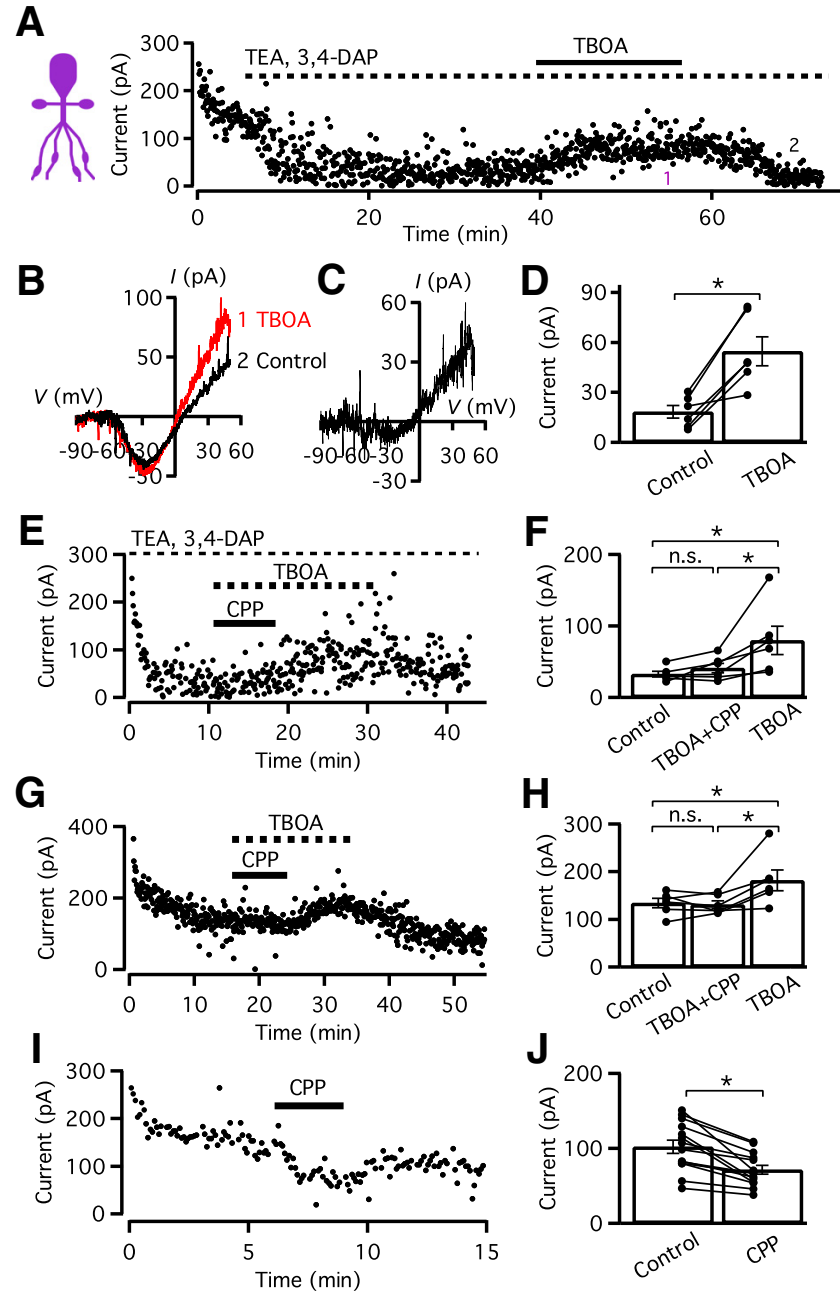

Figure 4. Blocking glutamate uptake evokes a conductance with J-shaped $I-V$ relationship in All amacrine cells. $A$, Current activated in an All increases when glutamate uptake is blocked by bath application of TBOA ( $50 \mu \mathrm{m}$; indicated by continuous horizontal line above data points). Here, and in $\boldsymbol{E}, \boldsymbol{G}$, and $\boldsymbol{I}$, each data point corresponds to current activated by a voltage-ramp stimulus ( $50 \mathrm{mV}$ to $-90 \mathrm{mV} ; 200 \mathrm{mV} / \mathrm{s}$; repeated at $1 \mathrm{~Hz}$ ) and measured by averaging the current between 35 and $45 \mathrm{mV}$ in the resulting $I-V$ relationship. Linear leak current was subtracted by first fitting a straight line to the $I-V$ relationship between -90 and $60 \mathrm{mV}$ and then subtracting the resulting function from the ramp current over the whole range of the voltage ramp. Here, and in $E, G$, and $I$, the extracellular solution contained $1 \mathrm{~mm} \mathrm{Mg}^{2+}$. During the early period of recording, the response is dominated by depolarization-evoked $\mathrm{K}^{+}$currents that are gradually suppressed by $\mathrm{Cs}^{+}$and TEA in the pipette solution $(0-7 \mathrm{~min})$. At $\sim 7 \mathrm{~min}$ recording time, TEA ( $20 \mathrm{~mm})$ and 3,4-DAP $(0.1 \mathrm{~mm}$ ) are added to the extracellular bath (broken horizontal line), leading to additional suppression of depolarization-evoked $\mathrm{K}^{+}$currents and a stable response plateau of $\sim 30 \mathrm{pA}$ ( $20-40 \mathrm{~min})$. Note the increase of depolarization-evoked current during application of TBOA and reduction after washout of TBOA. Numbers (1, red; 2, black) correspond to time points of $I-V$ traces displayed in $\boldsymbol{B}$. $\boldsymbol{B}$, Individual $I-V$ relationships (after linear leak subtraction) obtained by voltage-ramp stimuli applied during application of TBOA (1, red) and after washout of TBOA (2, black). C, I-V relationship of net TBOA-evoked current obtained by subtracting $I-V$ relationships in left panel ("TBOA"-"Control"). Note the J-shaped I-V relationship. D, Membrane current measured (as in A) in All amacrine cells ( $n=6$ cells) in control and in the presence of TBOA. Here and below, for each cell, current responses were averaged over $5 \mathrm{~min}$ in each condition. $\boldsymbol{E}$, Current activated in an All amacrine cell increases when glutamate uptake is blocked by bath application of TBOA (50 $\mu$ m; indicated by thick, broken, horizontal line above data points), but not when TBOA is applied in the presence of (PP ( $20 \mu \mathrm{m}$; indicated by continuous horizontal line above data points). Depolarization-evoked $\mathrm{K}^{+}$ currents blocked by $\mathrm{Cs}^{+}$and TEA in the pipette solution and by TEA $(20 \mathrm{~mm})$ and 3,4-DAP $(0.1$ $\mathrm{mm}$ ) in the extracellular solution (from the start of the recording; thin, broken, horizontal line above data points). Note the increase of depolarization-evoked current during application of TBOA alone, but not when TBOA was applied with CPP. $F$, Membrane current measured (as in $\boldsymbol{E}$ ) in All amacrine cells ( $n=6$ cells) in control, in the presence of TBOA and CPP, and sumably is enhanced by increasing the general excitability after blocking voltage-gated $\mathrm{K}^{+}$channels with TEA and 3,4-DAP in the bath solution. For some AII amacrine cells, we could detect activation of NMDA receptors under our baseline conditions not only by observing CPP-sensitive membrane noise (see above; Fig. $2 A, C)$, but also by observing a tonic current that was revealed by depolarization. For the AII amacrine cell illustrated in Figure 4I, the current evoked by voltage ramps was suppressed when CPP $(20 \mu \mathrm{M})$ was added to the bath solution. When CPP was washed out, the voltage ramp-evoked current reversed to the level measured before adding CPP (Fig. 4I). For AII amacrines tested in this way, the average current in the control condition was $102.1 \pm$ $8.7 \mathrm{pA}$; and in the presence of CPP, it decreased to $71.4 \pm 5.9 \mathrm{pA}$ $(p=0.000015$, paired $t$ test $n=14$ cells; Fig. $4 J)$. Together, these experiments directly demonstrate that increased ambient glutamate, evoked by blocking transporter activity, leads to an increase in NMDA receptor-mediated currents in AII amacrine cells.

\section{Single-channel properties determined by stationary noise analysis of NMDA-evoked currents}

We previously determined that the somas of AII and A17 amacrine cells lack detectable NMDA receptor responses (Zhou et al., 2016), limiting the possibilities for a more detailed investigation of the biophysical properties of these receptors by using outsideout or nucleated patches. Here, instead, we used stationary noise analysis of NMDA-evoked responses in whole-cell recordings of AII amacrine cells to elucidate single-channel properties of the NMDA receptor channels. Even for the relatively small AII amacrine cells, however, it is expected that channel gating noise generated in distal dendrites will be distorted by electrotonic filtering (Zandt et al., 2018); thus, no attempt was made to perform a similar analysis for A17 amacrine cells, which have much longer processes (Fig. 1E).

For these whole-cell recordings, we used a Cs ${ }^{+}-$and TEAbased intracellular solution to block potential activation of $\mathrm{K}^{+}$ channels activated by $\mathrm{Ca}^{2+}$ influx through the NMDA receptors, similar to what has been observed for olfactory bulb granule cells (Isaacson and Murphy, 2001). We first established a control condition by switching to a bath solution containing TTX, strychnine, bicuculline, and CNQX. Next, we changed to a $\mathrm{Mg}^{2+}$-free extracellular solution (containing the above blockers); and 5-10 min later, we added $50 \mu \mathrm{M}$ NMDA and $200 \mu \mathrm{M}$ D-serine to the bath solution. For the majority of AII amacrine cells tested ( 8 of 9 cells), bath application of NMDA evoked a slowly developing inward current. The inward current was accompanied by a

$\leftarrow$

in the presence of TBOA alone. $\mathbf{G}$, Current activated in an All amacrine cell increases when glutamate uptake is blocked by bath application of TBOA ( $50 \mu \mathrm{m}$; indicated by broken, horizontal line above data points), but not when TBOA is applied in the presence of the NMDA receptor antagonist (PP (20 $\mu \mathrm{m}$; indicated by continuous, horizontal line above data points). Depolarization-evoked $\mathrm{K}^{+}$currents blocked by $\mathrm{Cs}^{+}$and TEA in the pipette solution, but the extracellular solution did not contain $\mathrm{K}^{+}$channel blockers. Note the increase of depolarization-evoked current during application of TBOA alone, but not when TBOA was applied with (PP. $\boldsymbol{H}$, Membrane current measured (as in $\boldsymbol{G}$ ) in All amacrine cells $(n=6$ cells) in control, in the presence of TBOA + CPP, and in the presence of TBOA alone. $I$, Current activated in an All amacrine cell decreases when NMDA receptors are blocked by bath application of (PP (20 $\mu \mathrm{M}$; indicated by horizontal line above data points). Depolarization-evoked $\mathrm{K}^{+}$currents blocked by $\mathrm{Cs}^{+}$and TEA in the pipette solution, but the extracellular solution did not contain $\mathrm{K}^{+}$channel blockers. Note the decrease of depolarization-evoked current during application of (PP and reversal when CPP is washed out. $J$, Membrane current measured (as in $I$ ) in All amacrine cells ( $n=14$ cells) in control and in the presence of CPP. Statistical comparisons between averages: n.s., No significant difference $(p>0.05) .{ }^{*} p<0.05$. 
A

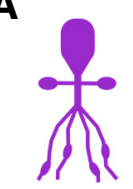

\section{Control}

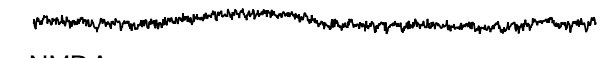

NMDA

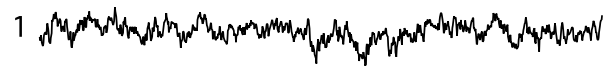

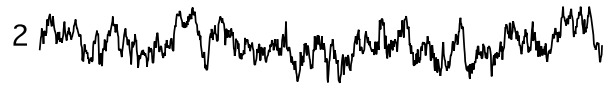
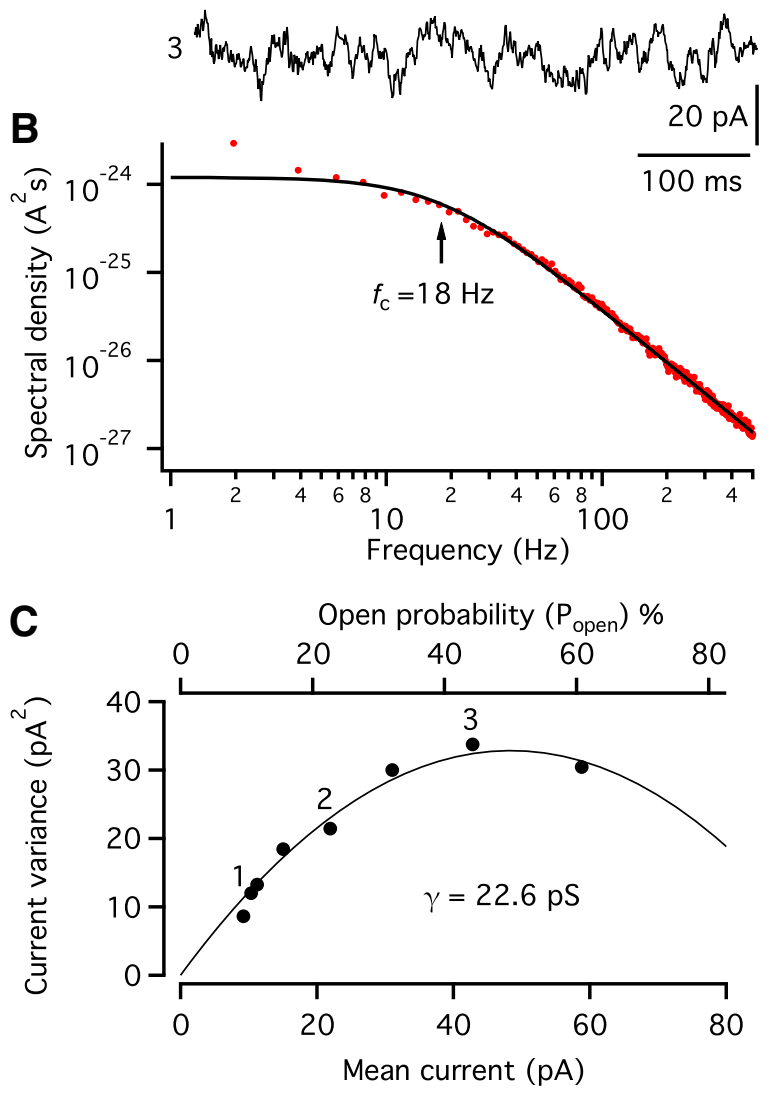

Figure 5. Stationary noise analysis of NMDA-evoked current in an All amacrine cell. $\boldsymbol{A}$, Control recording and responses evoked by bath application of NMDA (50 $\mu \mathrm{m})$. Traces 1-3 recorded at successive times after application of NMDA. Note the increasing membrane current noise during application of NMDA. $\boldsymbol{B}$, Net power density spectrum (red markers) obtained from the current noise evoked by $50 \mu \mathrm{m}$ NMDA during a 20 s period including trace 3 in $\boldsymbol{A}$. The power spectrum for the (net) NMDA-evoked noise has been fitted (continuous curve) with a Lorentzian function and the half-power cutoff (corner) frequency $\left(f_{c}\right)$ of the function is indicated by the vertical arrow. $\boldsymbol{C}$, Net current variance plotted against mean current for a series of different periods (as in $\boldsymbol{A}$ ) of NMDA-evoked responses in the same All amacrine cell. Each data point corresponds to a specific time period after NMDA was added to the bath. Data points 1-3 correspond to the periods in $\boldsymbol{A}$. The data points were obtained by power spectral density analysis (as in $\boldsymbol{B}$ ) and were fitted with a parabolic function (Eq. 4). The apparent single-channel current (i) was $1.4 \mathrm{pA}$ (corresponding to an apparent single-channel conductance of $22.6 \mathrm{pS}$ ) and the number of available receptor channels $(N)$ was 60 .

marked increase of current noise (Fig. 5A). The noise increased in parallel with the increase of current amplitude as the concentration of NMDA in the recording chamber increased over time. For each epoch of continuous recording under semistationary conditions (see Materials and Methods), we calculated net NMDAevoked noise spectra and fitted each averaged spectrum (typically between 1.95 and $500 \mathrm{~Hz})$ with one $(n=6$ cells) or two $(n=2$ cells) Lorentzian components. Figure $5 B$ shows the net spectrum and resulting curve fit for one such current epoch acquired after $\sim 9$ min of NMDA application. The half-power frequency $\left(f_{\mathrm{c}}=\right.$ $18 \mathrm{~Hz}$ ) is indicated by a vertical arrow. The corresponding time constant $(\tau)$ was $8.9 \mathrm{~ms}$. For the six AII amacrine cells that re- sponded to NMDA and were well fit by a single Lorentzian component, the mean time constant for the later ("saturating") responses was $8.03 \pm 0.72 \mathrm{~ms}$ (range 5.5-9.6 ms). For the two cells where an adequate fit required two Lorentzian components, the mean time constants were as follows: $\tau_{1}=0.5 \mathrm{~ms}, \tau_{2}=6.8 \mathrm{~ms}$ (cell 1) and $\tau_{1}=2.8 \mathrm{~ms}, \tau_{2}=12.5 \mathrm{~ms}$ (cell 2).

We estimated the net NMDA-evoked increase in current variance for each epoch as the integral under the sum of the Lorentzian function(s) fitted to each spectral density graph and plotted the resulting variance versus the mean current. When we obtained a series of epochs with slowly increasing mean current (as the concentration of NMDA in the recording chamber increased), the variance initially increased approximately linearly with mean current, consistent with a low open probability of the NMDA receptor channels (Fig. $5 \mathrm{C}$ ). With increasing mean current, the slope of the variance versus mean curve eventually declined; and for the majority of cells, the variance reached a peak followed by a slight decline (Fig. 5 C). The apparent unitary current (i) was estimated by fitting the data points with Equation 4 and the apparent unitary chord conductance $(\gamma)$ was calculated as $\gamma=i /\left(V_{\mathrm{m}}-E_{\text {rev }}\right)$, where $V_{\mathrm{m}}$ is the voltage-clamp potential and $E_{\text {rev }}$ is the reversal potential (assumed to be $0 \mathrm{mV}$ ) (compare Zhou et al., 2016). For the cell illustrated in Figure 5C, $\gamma$ was 22.6 pS. For the AII amacrine cells where the variance versus mean data points spanned a range large enough to be well fitted with Equation 4 ( $n=8$ cells), $\gamma$ was $22.6 \pm 1.3 \mathrm{pS}$ (range 17.1-27.1 pS). The curve fitting also estimated $N$ (the number of available channels in each cell) to be $57.9 \pm 7.0$ (range 38-94), corresponding to a maximum $P_{\text {open }}$ of $0.57 \pm 0.04$ (range 0.41-0.74). These numbers must be cautiously interpreted, however, as $N$ is unlikely to equate the total number of NMDA receptors on an AII amacrine cell because many receptors will have desensitized. In addition, it is likely that the responses were influenced by electrotonic low-pass filtering and attenuation in the dendritic tree.

\section{Pharmacological evidence for GluN2B-containing NMDA receptors in AII amacrine cells}

The subunit composition of NMDA receptors confers specific and distinct functional properties, such as $\mathrm{Mg}^{2+}$ sensitivity, $\mathrm{Ca}^{2+}$ permeability, affinity for glutamate, single-channel conductance, kinetics, and pharmacology (Paoletti et al., 2013). We took advantage of the differences in pharmacological properties between NMDA receptors with different subunit composition (Ogden and Traynelis, 2011). Because the majority of NMDA receptors in the CNS are composed of either GluN2A or GluN2B subunits (in combination with GluN1 subunits), we started our investigation with pharmacological agents that can differentiate between receptors with these subunits.

We first examined the effect of ifenprodil $(10 \mu \mathrm{M})$, an NMDA receptor antagonist with high selectivity for GluN2B-containing receptors (Williams, 1993; Perin-Dureau et al., 2002). For the AII cell illustrated in Figure 6A, ifenprodil reduced the amplitude of responses evoked by puffer-pipette application of NMDA ( $1 \mathrm{mM}$, 1 s) from $\sim 100 \mathrm{pA}$ to $\sim 20 \mathrm{pA}$, a reduction of $80 \%$ relative to control. When ifenprodil was washed out, the response slowly recovered, but by the time the cell was lost after $20 \mathrm{~min}$ recording, the recovery had only reached an amplitude that was $\sim 50 \%$ of the initial control response (Fig. 6A). Slow and incomplete recovery from block by ifenprodil has been observed previously for other preparations (Williams, 1993; Kew et al., 1996). For AII amacrine cells tested in this way, the average NMDA-evoked response in the presence of ifenprodil $(17.9 \pm 5.7 \mathrm{pA})$ was signficantly lower than in the control condition (111 $\pm 33 \mathrm{pA} ; p=0.029$, paired $t$ 
test), corresponding to a suppression of $84 \pm 4 \%(n=5$ cells; Fig. $6 A)$. Partial recovery after washout of ifenprodil was observed for 3 of 5 cells, with the response amplitude reaching an average of $63 \pm$ $19 \%$ of the baseline response.

When A17 amacrine cells were tested in the same way, ifenprodil had no effect on the NMDA-evoked responses, as illustrated for the cell in Figure $6 B$ where the response amplitude was $\sim 80 \mathrm{pA}$ in the control condition and $\sim 82 \mathrm{pA}$ in the presence of ifenprodil. For A17 amacrine cells, the average NMDA-evoked response was $82 \pm 10 \mathrm{pA}$ in the control condition and $80 \pm 11$ in the presence of ifenprodil ( $p=$ 0.2725 , paired $t$ test), corresponding to a change of only $3 \pm 2 \%(n=8$ cells; Fig. $6 B)$. These results suggested that AII amacrine cells express NMDA receptors that contain the GluN2B subunit, whereas A17 amacrines do not.

To substantiate this conclusion, we also examined the effect of Ro 25-6981 (1 $\mu \mathrm{M})$, a more potent derivative of ifenprodil that is highly specific for NMDA receptors containing the GluN2B subunit (Fischer et al., 1997). For the AII amacrine cell illustrated in Figure 6C, application of Ro 25-6981 reduced the NMDA-evoked response from $\sim 110 \mathrm{pA}$ to $\sim 3 \mathrm{pA}$, corresponding to an amplitude reduction of 90\%. The cell was lost before Ro 25-6981 could be washed out, but partial recovery of NMDA-evoked responses was observed for AII cells in which recordings could be maintained for at least $15 \mathrm{~min}$ after we started to wash out Ro 25-6981. For AII amacrine cells tested with Ro 256981, the average NMDA-evoked response in the presence of Ro 25-6981 ( $4 \pm 1 \mathrm{pA}$ ) was significantly lower than in the control condition ( $68 \pm 14 \mathrm{pA})$ corresponding to a suppression of $93 \pm 2 \%$ ( $n=6$ cells; $p=0.0053$, paired $t$ test; Fig. $6 C)$. For A17 amacrine cells, application of Ro 25-6981 did not change the NMDA-evoked currents. For the cell illustrated in Figure $6 D$, the response was $\sim 103 \mathrm{pA}$ in the control condition and $\sim 105 \mathrm{pA}$ in the presence of Ro 25-6981. For A17 amacrines, the average control response was $102 \pm 15 \mathrm{pA}$ and the average response in Ro 25-6981 was $110 \pm 17 \mathrm{pA}$ corresponding to a change of only $6 \pm 6 \%(n=6$ cells; $p=0.25$, paired $t$ test; Fig. $6 D$ ). Together, these results provided strong evidence for the presence of GluN2B subunits in the NMDA receptors of AII amacrine cells and suggested that GluN2B is absent from the NMDA receptors of A17 amacrine cells.

Pharmacological evidence for GluN2A-containing NMDA receptors in $\mathrm{A} 17$ amacrine cells

To test for NMDA receptors containing the GluN2A subunit, we examined the effect of $\mathrm{Zn}^{2+}$, which acts as a specific, voltage-
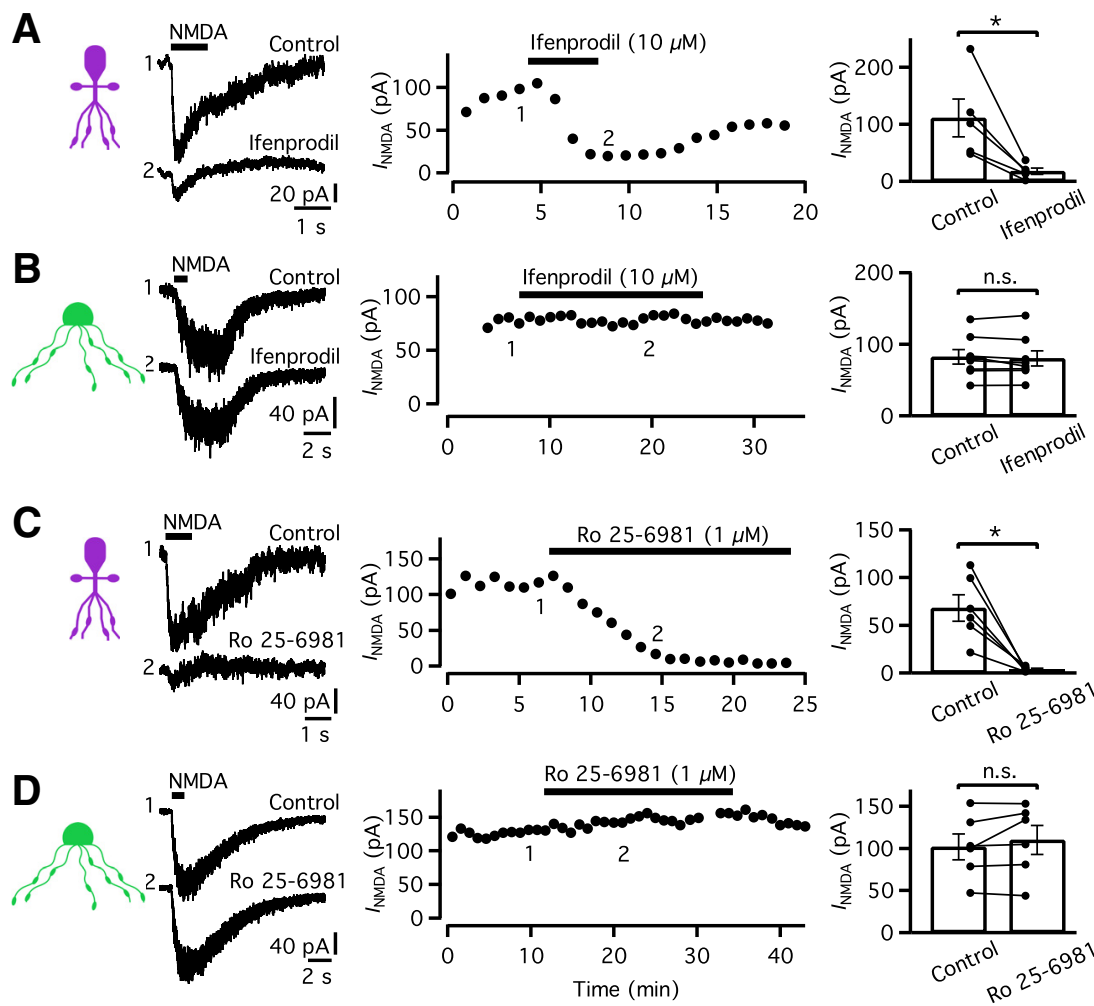

Figure 6. NMDA-evoked responses in All, but not A17, amacrines are blocked by the GluN2B-selective antagonists ifenprodil and Ro 25-6981. A, Left, Responses evoked by NMDA application in an All amacrine cell by pressure application of NMDA (1 mM, s) from a puffer pipette in the control condition (1) and in the presence of $10 \mu \mathrm{m}$ ifenprodil in the bath (2). In this and subsequent 作ed responses during addition of ifenprodil. Here and in Figures 7 and 8, numbered data points ( 1 and 2 ) correspond to responses of data traces displayed at left. Right, Peak amplitude of NMDA-evoked responses in All amacrine cells ( $n=5$ cells) in control and in the presence of ifenprodil. $\boldsymbol{B}$, Left, Responses evoked by NMDA application in an A17 amacrine cell by pressure (2). Middle, Peak amplitude of currents activated in the same A17 amacrine cell by application of NMDA (as to the left) at $60 \mathrm{~s}$ intervals. Note the lack of effect on NMDA-evoked responses during addition of ifenprodil. Right, Peak amplitude of NMDA-evoked application in an All amacrine cell by pressure application of NMDA (1 mM, 1s) from a puffer pipette in the control condition (1) and Right, Peak amplitude of NMDA-evoked responses in All amacrine cells ( $n=6$ cells) in control and in the presence of $R_{0}$ D, Left, Responses evoked by NMDA application in an A17 amacrine cell by pressure application of NMDA (1 mm, 1s) from a puffer pipette in the control condition (1) and in the presence of $1 \mu \mathrm{m}$ Ro 25-6981 (2). Middle, Peak amplitude of currents activated in the same A17 amacrine cell by application of NMDA (as to the left) at 60 s intervals. Note the lack of effect on ( $n=6$ cells) in control and in the presence of Ro 25-6981. Statistical comparisons between averages: n.s., No significant difference $(p>0.05)$. ${ }^{*} p<0.05$.

independent, noncompetitive, high-affinity $\left(I C_{50}=20 \mathrm{nM}\right)$ antagonist of GluN2A-containing NMDA receptors. The maximum degree of inhibition by $\mathrm{Zn}^{2+}$ that can be expected is $\sim 60 \%-80 \%$ (Paoletti et al., 2009). However, under normal experimental conditions, nanomolar concentrations of $\mathrm{Zn}^{2+}$ can be found as a contamination in different chemical compounds and are sufficient to block GluN2A-containing NMDA receptors, potentially obscuring their presence (Paoletti et al., 2009). In addition, $\mathrm{Zn}^{2+}$ can be colocalized with glutamate in synaptic vesicles and is coreleased with glutamate during exocytosis (Smart et al., 1994). For simplicity, we collectively refer to these sources as contaminating $\mathrm{Zn}^{2+}$. To work around this complication, we used tricine to chelate contaminating $\mathrm{Zn}^{2+}$ and buffer $\mathrm{Zn}^{2+}$ at a controlled level (Paoletti et al., 2009). To investigate the potential relevance of 
A
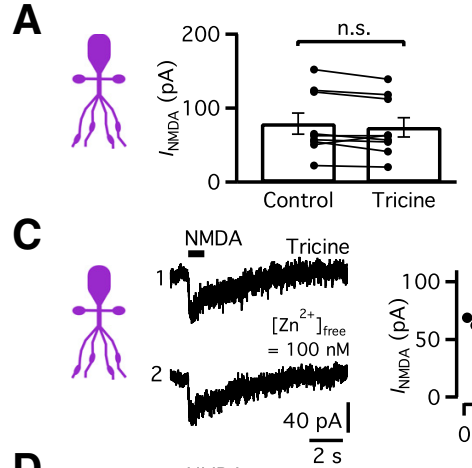

E
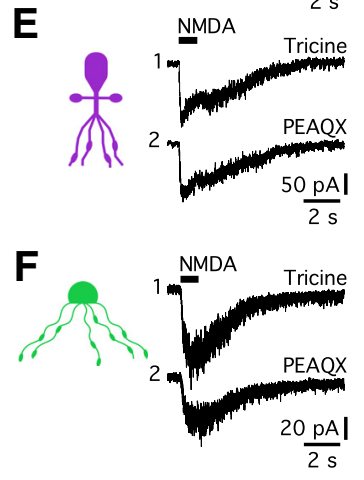

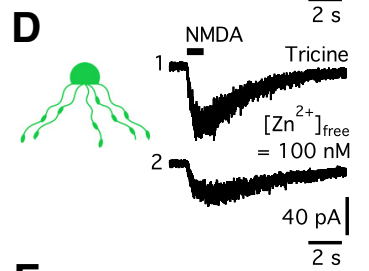

B
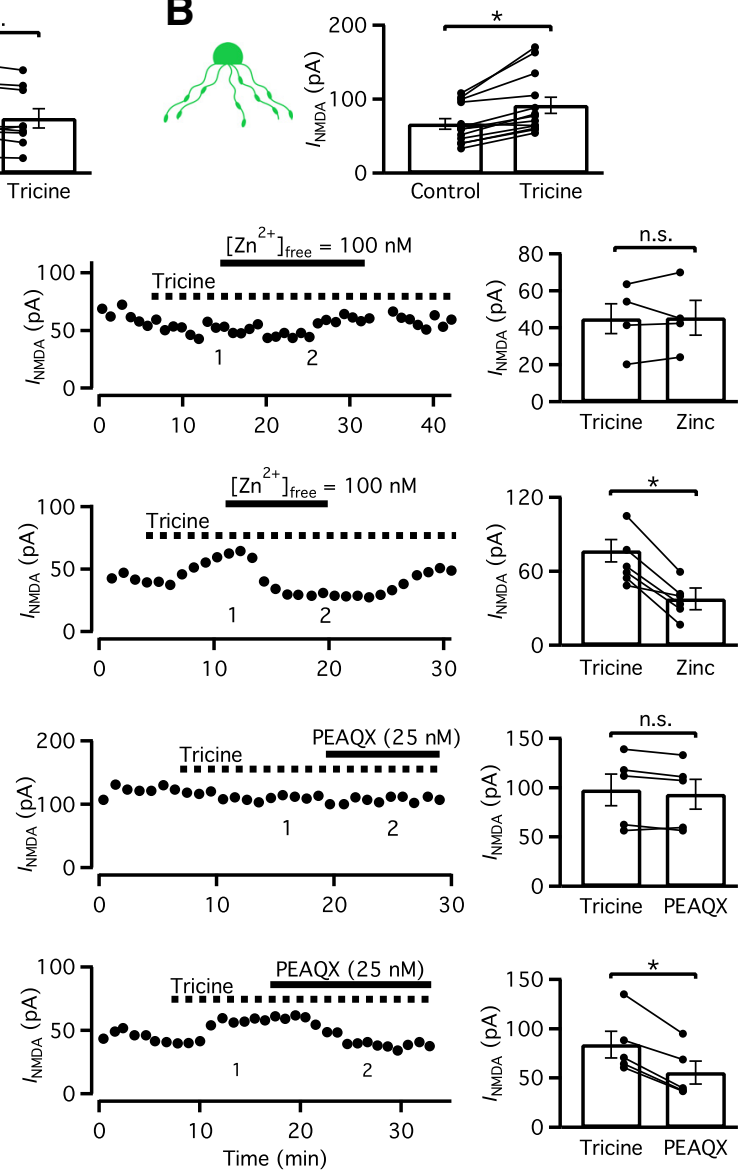

Figure 7. NMDA-evoked responses in A17, but not All amacrines, are increased by chelating potentially contaminating trace amounts of $\mathrm{Zn}^{2+}$ with tricine in the extracellular solution. NMDA-evoked responses in A17, but not All amacrines, are blocked by the GluN2A-selective antagonist $\mathrm{Zn}^{2+}$. $\boldsymbol{A}$, Peak amplitude of currents activated in All amacrine cells ( $n=9$ cells) by repeated pressure application of NMDA $(1 \mathrm{~mm}, 1 \mathrm{~s})$ from a puffer pipette at $60 \mathrm{~s}$ intervals, first in control and then in the presence of tricine $(10 \mathrm{~mm})$. Note the lack of effect on NMDA responses after adding tricine. $\boldsymbol{B}$, Peak amplitude of currents activated in A17 amacrine cells $(n=13$ cells) by repeated pressure application of NMDA $(1 \mathrm{~mm}, 1 \mathrm{~s})$ from a puffer pipette at $60 \mathrm{~s}$ intervals, first in control and then in the presence of tricine $(10 \mathrm{~mm})$. Note the increase of responses after adding tricine compared with control. C, Left, Responses evoked by NMDA application in an All amacrine cell by pressure application of NMDA (1 mM, 1 s) from a puffer pipette in the control condition (after adding $10 \mathrm{~mm}$ tricine; 1 ) and in the presence of tricine and $\mathrm{ZnCl}_{2}$ (to achieve a free concentration of $\mathrm{Zn}^{2+}\left(\left[\mathrm{Zn}^{2+}\right]_{\text {free }}\right)$ of $\left.100 \mathrm{~nm} ; 2\right)$. Middle, Peak amplitude of currents activated in the same All amacrine cell by application of NMDA (as to the left) at 60 s intervals. After a brief period, the extracellular solution was supplemented with tricine to chelate potentially contaminating trace amounts of $\mathrm{Zn}^{2+}$ before adding $\mathrm{ZnCl}_{2}$. Note the lack of effect on NMDA-evoked responses by $\mathrm{Zn}^{2+}$ $\left(\left[\mathrm{Zn}^{2+}\right]_{\text {free }}=100 \mathrm{~nm}\right)$. Right, Peak amplitude of NMDA-evoked responses in All amacrine cells ( $n=4$ cells) in tricine and with tricine and $\left[\mathrm{Zn}^{2+}\right]_{\text {free }}=100 \mathrm{~nm}$ ("Zinc"). D, Left, Responses evoked by NMDA application in an A17 amacrine cell by pressure application of NMDA (1 mM, 1 s) from a puffer pipette in the control condition (after adding tricine; 1 ) and in the presence of tricine and $\mathrm{ZnCl}_{2}\left(\left[\mathrm{Zn}^{2+}\right]_{\text {free }}=100 \mathrm{~nm} ; 2\right)$. Middle, Peak amplitude of currents activated in the same A17 amacrine cell by application of NMDA (as to the left) at $60 \mathrm{~s}$ intervals. After a brief period, the extracellular solution was supplemented with tricine $(10 \mathrm{~mm})$ to chelate potentially contaminating trace amounts of $\mathrm{Zn}^{2+}$ before adding $\mathrm{ZnCl}_{2}$. Note the enhancement of responses after adding tricine and suppression of responses after addition of $\mathrm{ZnCl}_{2}$. Right, Peak amplitude of NMDA-evoked responses in A17 amacrine cells $\left(n=6\right.$ cells) in tricine $(10 \mathrm{~mm})$ and with tricine $(10 \mathrm{~mm})$ and $\left[\mathrm{Zn}^{2+}\right]_{\text {free }}=100 \mathrm{~nm}$ ("Zinc"). $\boldsymbol{E}$, Left, Responses evoked by NMDA application in an All amacrine cell by pressure application of NMDA (1 mM, 1 s) from a puffer pipette in the control condition (in the presence of $10 \mathrm{~mm}$ tricine; 1 ) and in the presence of tricine and $25 \mathrm{~nm}$ PEAQX (2). Middle, Peak amplitude of currents activated in the same All amacrine cell by application of NMDA (as to the left) at $60 \mathrm{~s}$ intervals. After a brief period, the extracellular solution was supplemented with tricine $(10 \mathrm{~mm})$ to chelate potentially contaminating trace amounts of $\mathrm{Zn}^{2+}$ to alleviate any block of GluN2Acontaining NMDA receptors. Note the lack of effect on NMDA-evoked responses by PEAQX. Right, Peak amplitude of NMDA-evoked responses in All amacrine cells $(n=5$ cells) in tricine and in the presence of tricine and PEAQX ("PEAQX"). $\boldsymbol{F}$, Left, Responses evoked by NMDA application in an A17 amacrine cell by pressure application of NMDA $(1 \mathrm{~mm}, 1 \mathrm{~s})$ from a puffer pipette in the control condition (in the presence of $10 \mathrm{~mm}$ tricine; 1) and in the presence of tricine and PEAQX (2). Middle, Peak amplitude of currents activated in the same $\mathrm{A} 17$ amacrine cell by application of NMDA (as to the left) at 60 sintervals. After a brief period, the extracellular solution was supplemented with tricine $(10 \mathrm{~mm})$ to chelate potentially contaminating trace amounts of $\mathrm{Zn}^{2+}$ to alleviate any block of GluN2A-containing NMDA receptors. Note the suppression of NMDA-evoked responses by PEAQX. Right, Peak amplitude of NMDA-evoked responses in A17 amacrine cells ( $n=5$ cells) in tricine and in the presence of tricine and PEAQX ("PEAQX"). Statistical comparisons between averages: $n$.s., No significant difference $(p>0.05) .{ }^{*} p<0.05$. contaminating levels of $\mathrm{Zn}^{2+}$ under our conditions, we recorded from both AII and A17 amacrine cells and acquired baseline NMDA-evoked responses (as above). After a stable baseline had been established, we added tricine at a concentration of $10 \mathrm{~mm}$ (Paoletti et al., 2009) to chelate any contaminating $\mathrm{Zn}^{2+}$, which may have suppressed the baseline NMDA-evoked responses.

For AII amacrine cells, the NMDA responses evoked in the presence of tricine $(10 \mathrm{mM})$, had an average peak amplitude of $74 \pm 13 \mathrm{pA}$, not significantly different from the responses obtained in the control condition without tricine $(79 \pm 14$ $\mathrm{pA} ; n=9$ cells; $p=0.1177$, paired $t$ test; Fig. 7A). However, for A17 amacrine cells, the average peak amplitude of NMDA responses evoked in the presence of tricine was $92 \pm 11 \mathrm{pA}$, significantly larger than the responses obtained in the control condition without tricine $(66.5 \pm 7.2 \mathrm{pA} ; n=$ 13 cells; $p=0.0004$, paired $t$ test; Fig. $7 B)$, and corresponded to an increase of $39 \pm$ $6 \%$. These effects of tricine suggested that the NMDA receptors on A17, but not AII, amacrine cells were suppressed by endogenous or contaminating $\mathrm{Zn}^{2+}$ under our recording conditions.

To test potential effects of $\mathrm{Zn}^{2+}$ directly, we recorded from both cell types with tricine present in the control condition and then changed to an extracellular solution with a free $\mathrm{Zn}^{2+}$ concentration $\left(\left[\mathrm{Zn}^{2+}\right]_{\text {free }}\right)$ of $100 \mathrm{~nm}$ (see Materials and Methods). For AII amacrine cells, the average NMDA-evoked response in the presence of $100 \mathrm{~nm}$ free $\mathrm{Zn}^{2+}$ was $45.3 \pm$ $9.4 \mathrm{pA}$, not significantly different from that in the control with tricine $(44.8 \pm 9.4$ $\mathrm{pA}, n=4$ cells; $p=0.8763$, paired $t$ test; Fig. $7 C$ ). These results suggested that the NMDA receptors expressed by AII amacrine cells are not inhibited by nanomolar concentrations of $\mathrm{Zn}^{2+}$, and thus are unlikely to contain the GluN2A subunit.

When A17 amacrine cells were tested in the same way, we found that $100 \mathrm{~nm}$ $\mathrm{Zn}^{2+}$ (in the extracellular solution with $10 \mathrm{~mm}$ tricine) markedly suppressed the NMDA-evoked responses of these cells. For the cell illustrated in Figure $7 D, \mathrm{Zn}^{2+}$ reduced the response to NMDA to $\sim 30$ $\mathrm{pA}$, corresponding to a decrease of $50 \%$ relative to the control with tricine. For A17 amacrine cells tested in this way, the average NMDA-evoked response in the presence of $100 \mathrm{nM} \mathrm{Zn}^{2+}$ was $36.1 \pm 7.1$ $\mathrm{pA}$, significantly lower than in the control condition with tricine $(71.9 \pm 9.1 \mathrm{pA}, n=6$ 
cells; $p=0.0002$, paired $t$ test; Fig. $7 D$ ), and corresponded to a reduction of $51 \pm$ $5 \%$. These results suggested that the NMDA receptors expressed by A17 amacrine cells are inhibited by nanomolar concentrations of $\mathrm{Zn}^{2+}$, and thus are likely to contain the GluN2A subunit.

To substantiate these results, we examined the effect of PEAQX, an antagonist that is selective for GluN2A-containing NMDA receptors (Frizelle et al., 2006). We tested the effect of PEAQX (25 nM) in the presence of tricine to eliminate the possibility that potential GluN2A-containing NMDA receptors would already be blocked by contaminating levels of $\mathrm{Zn}^{2+}$. In this condition, PEAQX had no effect on NMDA-evoked responses in AII amacrine cells (Fig. 7E). The average response in the control with tricine was $98 \pm 16 \mathrm{pA}$, and the average response in the presence of PEAQX was $94 \pm 15 \mathrm{pA}(n=5$ cells; $p=$ 0.0879 , paired $t$ test; Fig. $7 E$ ).

When A17 amacrine cells were tested with PEAQX (in the presence of tricine), the results were very different from those obtained for AII amacrine cells. For the cell illustrated in Figure 7F, PEAQX suppressed the NMDA-evoked response from $\sim 60 \mathrm{pA}$ in the control with tricine to $\sim 36 \mathrm{pA}$ after 10 min in PEAQX, corresponding to a reduction of $40 \%$. In the presence of PEAQX, the average NMDA-evoked response in A17 amacrines was $55 \pm 12 \mathrm{pA}$, significantly lower than in the tricine condition $(84 \pm 14$ $\mathrm{pA} ; n=5$ cells; $p=0.00127$, paired $t$ test; Fig. $7 F$ ), corresponding to an average suppression of $36 \pm 4 \%$. Together, these results provided strong evidence for the presence of the GluN2A subunit in NMDA receptors of A17 amacrine cells and suggested that GluN2A is absent from the NMDA receptors of AII amacrine cells.

\section{No evidence for expression of GluN2C and GluN2D receptor subunits in AII and $\mathrm{A} 17$ amacrine cells}

The functional properties of NMDA receptors containing GluN2C and/or GluN2D subunits differ substantially from those containing GluN2A and/or GluN2B subunits (Paoletti et al., 2013). The receptor antagonists QNZ46 (Hansen and Traynelis, 2011) and DQP-1105 (Acker et al., 2011) are sufficiently selective for GluN2C- and GluN2D-containing NMDA receptors that they can be used to differentiate them from GluN2Aand GluN2B-containing receptors. Unfortunately, there are currently no NMDA receptor antagonists available that can adequately distinguish between GluN2C- and GluN2D-containing receptors. However, there is evidence from in situ hybridization studies in adult rat retina that GluN2C, but not GluN2D, is expressed by subsets of amacrine cells (in addition to GluN2A and GluN2B) (Brandstätter et al., 1994).
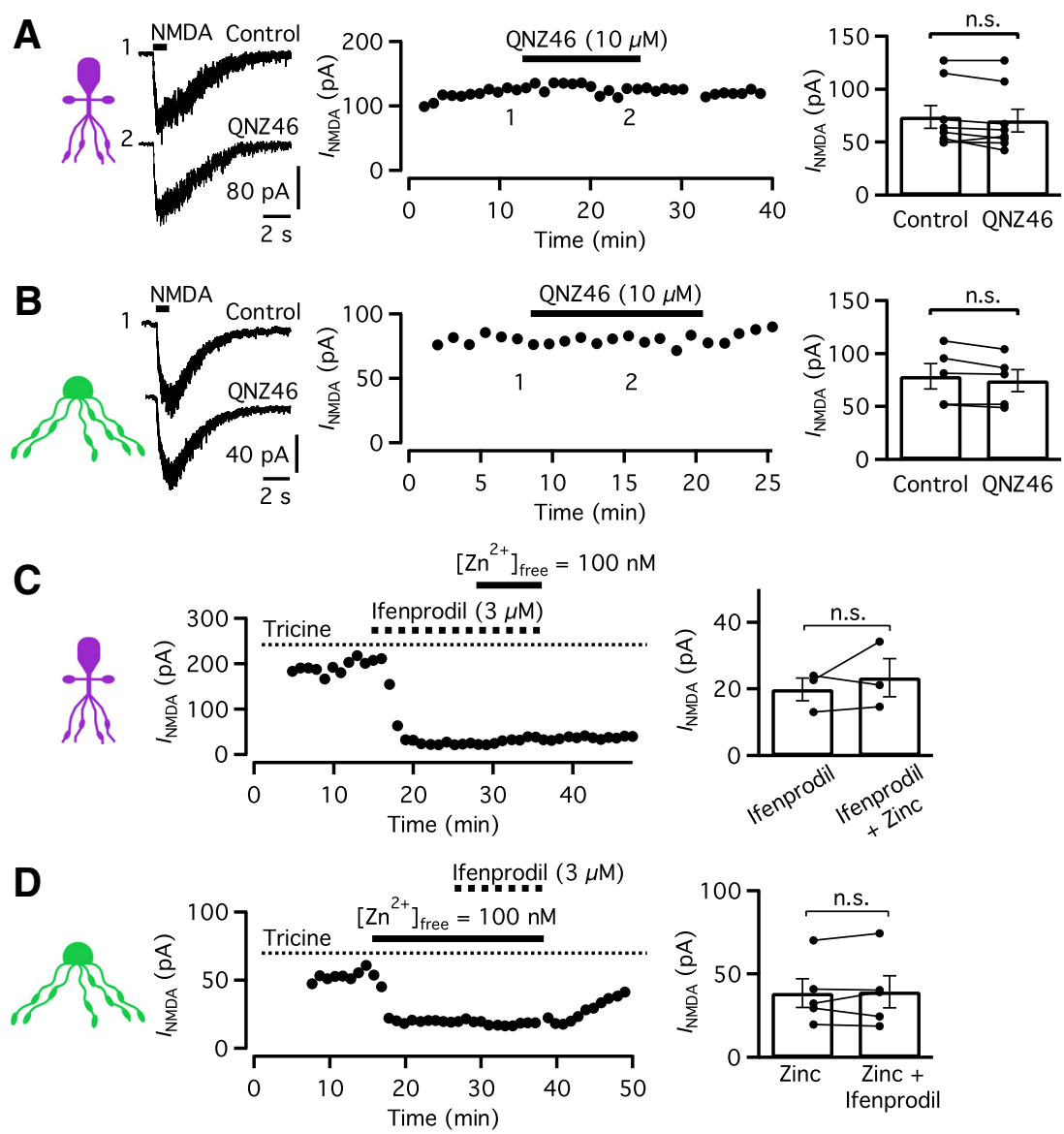

Figure 8. No evidence for expression of GluN2C/GluN2D subunits or triheteromeric GluN1/GluN2A/GluN2B NMDA receptors in All or A17 amacrine cells. A, Left, Responses evoked by NMDA application in an All amacrine cell by pressure application of NMDA $(1 \mathrm{~mm}, 1 \mathrm{~s})$ from a puffer pipette in the control condition and in the presence of $10 \mu \mathrm{m}$ QNZ46 (2). Middle, Peak amplitude of currents activated in the same All amacrine cell by application of NMDA (as to the left) at 60 s intervals. Note the lack of effect on NMDA-evoked responses during addition of QNZ46 $(10 \mu \mathrm{M})$ to the bath. Right, Peak amplitude of NMDA-evoked responses in All amacrine cells ( $n=8$ cells) in control and in the presence of QNZ46. $\boldsymbol{B}$, Left, Responses evoked by NMDA application in an A17 amacrine cell by pressure application of NMDA $(1 \mathrm{~mm}, 1 \mathrm{~s})$ from a puffer pipette in the control condition and in the presence of 10 $\mu \mathrm{M}$ QNZ46 (2). Middle, Peak amplitude of currents activated in the same A17 amacrine cell by application of NMDA (as to the left) at 60 sintervals. Note the lack of effect on NMDA-evoked responses during addition of QNZ46 $(10 \mu \mathrm{M})$ to the bath. Right, Peak amplitude of NMDA-evoked responses in A17 amacrine cells $(n=5$ cells) in control and in the presence of QNZ46. C, Left, Peak amplitude of currents activated in an All amacrine cell by pressure application of NMDA ( $1 \mathrm{~mm}, 1 \mathrm{~s}, 60$ sintervals). During the first recording period, tricine $(10 \mathrm{~mm})$ was added to the bath to chelate potentially contaminating trace amounts of $\mathrm{Zn}^{2+}$ to avoid baseline suppression of GluN2A-containing receptors. Next, a relatively low concentration of ifenprodil $(3 \mu \mathrm{m})$ was added to block diheteromeric GluN1/GluN2B receptors. Finally, the free $\mathrm{Zn}^{2+}$ concentration was set to $100 \mathrm{~nm}$ (by adding $\mathrm{ZnCl}_{2}$ ) to test for the presence of potential triheteromeric GluN1/GluN2A/GluN2B receptors that would presumably be blocked by the combination of ifenprodil and $\mathrm{Zn}^{2+}$. There was no additional suppression by adding $\mathrm{Zn}^{2+}$. Right, Peak amplitude of NMDA-evoked responses in All amacrine cells ( $n=3$ cells) in the presence of tricine and ifenprodil ( $3 \mu \mathrm{M}$; "Ifenprodil"), and in the presence of tricine, ifenprodil, and $\mathrm{Zn}^{2+}(100 \mathrm{~nm}$; "Ifenprodil + Zinc"). D, Left, Peak amplitude of currents activated in an $A 17$ amacrine cell by pressure application of $\mathrm{NMDA}(1 \mathrm{~mm}, 1 \mathrm{~s}, 60$ sintervals). During the firstrecording period, tricine $(10 \mathrm{~mm})$ was added to the bath to chelate potentially contaminating trace amounts of $\mathrm{Zn}^{2+}$ to avoid baseline suppression of GluN2A-containing receptors. Next, the free $\mathrm{Zn}^{2+}$ concentration was set to $100 \mathrm{~nm}$ (by adding $\mathrm{ZnCl}_{2}$ ) to block diheteromeric GluN1/GluN2A receptors. Finally, ifenprodil was added $(3 \mu \mathrm{M})$ to testfor block of triheteromericGluN1/GluN2A/GluN2B receptors by the combination of $\mathrm{Zn}^{2+}$ and ifenprodil. There was no additional suppression by adding ifenprodil. Right, Peak amplitude of NMDA-evoked responses in A17 amacrine cells $(n=5$

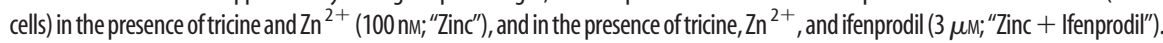
Statistical comparisons between averages: $n$.S., No significant difference $(p>0.05)$.

There was no effect of QNZ46 (10 $\mu \mathrm{M})$ on NMDA-evoked responses in either AII or A17 amacrine cells (Fig. 8A,B). For AII amacrines, the average response amplitude was $74 \pm 11 \mathrm{pA}$ in control and $70 \pm 11 \mathrm{pA}$ in QNZ46 ( $p=0.1295$, paired $t$ test; $n=$ 8 cells; Fig. $8 A$ ). For A17 amacrines, the average was $79 \pm 12 \mathrm{pA}$ in control and $74 \pm 11 \mathrm{pA}$ in QNZ46 ( $p=0.0742$, paired $t$ test; $n=$ 5 cells; Fig. $8 B$ ). These results suggested that neither AII nor A17 amacrine cells express GluN2C or GluN2D subunits. The results 
with QNZ46 were supported by those obtained with DQP-1105 $(10 \mu \mathrm{M})$, which also had no effect on the NMDA-evoked responses in either AII or A17 amacrine cells. For AII amacrines, the average was $87 \pm 17 \mathrm{pA}$ in control and $83 \pm 16 \mathrm{pA}$ in DQP1105 ( $p=0.4561$, paired $t$ test; $n=8$ cells; data not shown). For A17 amacrines, the average was $77 \pm 17 \mathrm{pA}$ in control and $75 \pm$ 17 in DQP-1105 ( $p=0.6218$, paired $t$ test; $n=7$ cells; data not shown). Together, the results with GluN2C- and GluN2Dselective antagonists strongly suggested the absence of these subunits from the NMDA receptors expressed by AII and A17 amacrine cells.

\section{No evidence for expression of triheteromeric NMDA receptors in AII and A17 amacrines}

The majority of NMDA receptors in the CNS contain either two GluN2A or two GluN2B subunits in combination with two obligatory GluN1 subunits (Hansen et al., 2014). However, there is also the potential for NMDA receptors to form triheteromeric receptors with one GluN2A and one GluN2B subunit in addition to two GluN1 subunits, as demonstrated in the hippocampus and forebrain (for review, see Hansen et al., 2014). The functional and pharmacological properties of triheteromeric NMDA receptors are a mix between the two diheteromeric receptor subtypes (Hatton and Paoletti, 2005; Tovar et al., 2013). Specifically, $\mathrm{Zn}^{2+}$ has been demonstrated to be equally effective as an antagonist of diheteromeric GluN2A-containing receptors and triheteromeric GluN2A/GluN2B-containing receptors (Hatton and Paoletti, 2005). Furthermore, in recombinant expression systems, ifenprodil (at the low concentration of 1-3 $\mu \mathrm{M}$ ) blocks triheteromeric GluN2A/GluN2B-containing receptors, but only by $\sim 20 \%$ (Hatton and Paoletti, 2005; Hansen et al., 2014). On this background, our results described above suggest that it is unlikely that AII amacrine cells have a significant population of functional triheteromeric receptors, as neither tricine nor nanomolar concentrations of $\mathrm{Zn}^{2+}$ had any effect on the NMDA-evoked currents. Similarly, it is unlikely that A17 amacrine cells have a significant population of functional triheteromeric receptors, as ifenprodil had no effect on the NMDA-evoked currents in these cells.

However, if there is only a small population of triheteromeric NMDA receptors on either cell type, responses mediated by these receptors might be masked by the pharmacological properties of the predominant diheteromeric receptors. Importantly, the inhibition of triheteromeric receptors by ifenprodil and $\mathrm{Zn}^{2+}$ is superadditive (Hatton and Paoletti, 2005), meaning that the inhibition observed when one antagonist is applied in a background of the other, is larger than if the same antagonist is applied alone. Thus, we decided to use a combination of the antagonists ifenprodil and $\mathrm{Zn}^{2+}$ to directly test for the presence of triheteromeric receptors among the AII and A17 NMDA receptors. For AII amacrines, we tested the effect of $\mathrm{Zn}^{2+}$ in a background of ifenprodil; and for A17 amacrines, we tested the effect of ifenprodil in a background of $\mathrm{Zn}^{2+}$.

For both AII and A17 amacrine cells, we applied NMDA (1 $\mathrm{mM}, 1 \mathrm{~s})$ in an extracellular solution that contained tricine (10 $\mathrm{mM}$ ) to ensure that any potential triheteromeric GluN2A/ GluN2B receptors were not already blocked by contaminating $\mathrm{Zn}^{2+}$ (Fig. $8 C, D$ ). For the AII amacrines, we then switched to an extracellular solution with a low concentration of ifenprodil (3 $\mu \mathrm{M})$ to block diheteromeric GluN2B-containing receptors without completely blocking potential triheteromeric GluN2A/ GluN2B-containing receptors (Hatton and Paoletti, 2005; Hansen et al., 2014). Similar to the higher concentration of ifenprodil (10 $\mu \mathrm{M}$; see above), $3 \mu \mathrm{M}$ ifenprodil had a strong inhibitory effect on the NMDA-evoked responses in AII amacrines (Fig. $8 C$ ). After obtaining a stable baseline, we switched to an extracellular solution with a free $\mathrm{Zn}^{2+}$ concentration of $100 \mathrm{~nm}$, but the addition of $\mathrm{Zn}^{2+}$ had no additional inhibitory effect (Fig. 8C). For AII amacrines tested in this way, the average NMDA-evoked current in the presence of ifenprodil was $20.1 \pm 3.5 \mathrm{pA}$. With addition of $100 \mathrm{~nm}$ free $\mathrm{Zn}^{2+}$ in a background of ifenprodil, the NMDA response did not change, with an average of $22.2 \pm 4.8 \mathrm{pA}$ ( $p=0.5493$, paired $t$ test; $n=3$ cells; Fig. $8 C$ ). Thus, it is unlikely that AII amacrine cells express a significant population of functional triheteromeric GluN2A/GluN2B-containing receptors.

For the A17 amacrines, switching to an extracellular solution with $100 \mathrm{~nm}$ free $\mathrm{Zn}^{2+}$ strongly inhibited the NMDA-evoked responses (Fig. $8 D$ ). After obtaining a stable baseline, we switched to an extracellular solution with a low concentration of ifenprodil $(3 \mu \mathrm{M})$, but the addition of ifenprodil had no additional inhibitory effect (Fig. 8D). For A17 amacrines tested in this way, the average NMDA-evoked current in the presence of $100 \mathrm{~nm}$ free $\mathrm{Zn}^{2+}$ (and tricine) was $38.5 \pm 8.6 \mathrm{pA}$. With the addition of ifenprodil in a background of $100 \mathrm{nM}$ free $\mathrm{Zn}^{2+}$, the NMDA response did not change, with an average of $39.4 \pm 9.7 \mathrm{pA}(p=$ 0.6855 , paired $t$ test; $n=5$ cells; Fig. $8 D$ ). Thus, as for AII amacrines, it is unlikely that A17 amacrines express a significant population of functional triheteromeric GluN2A/GluN2Bcontaining receptors.

\section{Morphological evidence for expression of GluN2B in AII amacrine cells and GluN2A in A17 amacrine cells}

Our pharmacological experiments strongly suggested a remarkable complementary expression of NMDA receptors in the postsynaptic targets of rod bipolar cells, with GluN2B-containing receptors in AII amacrine cells and GluN2A-containing receptors in A17 amacrine cells. To examine the relationship between the dendritic processes of these amacrine cells and NMDA receptor subunit expression, we injected AII and A17 amacrine cells in retinal slices with Alexa-488, immunolabeled the slices for either GluN2B or GluN2A, and acquired confocal image stacks.

We observed clear colocalization of GluN2B with AII, but not A17 amacrine cells (Fig. 9). Figure 9A shows a maximum intensity projection (MIP) of a confocal stack from a slice with an injected AII amacrine cell and immunolabeled for GluN2B. The labeling for GluN2B appears punctate across the inner plexiform layer, with higher density of punctae in the proximal part, corresponding approximately to sublamina $b$. It is commonly assumed that when synaptic (in contrast to extrasynaptic) receptors are immunolabeled with fluorescent antibodies, the labeling will appear punctate, with each punctum corresponding to a cluster of receptors in a postsynaptic density. In the case of NMDA receptors, however, this cannot be assumed to be correct, as there is evidence that extrasynaptic NMDA receptors can be organized in a clustered fashion (Petralia et al., 2010; Papouin and Oliet, 2014). Visual inspection of single slices (in the $X Y$ plane) of the confocal stack, with the two channels (AII and GluN2B) overlaid, identified multiple examples of GluN2B punctae that overlapped with processes of the AII amacrine cell (Fig. $9 B, C$ ). In most cases, colocalization between AII processes and GluN2B punctae was detected at the arboreal dendrites (Fig. 9C), but we could also find a few examples of GluN2B colocalized with lobular dendrites (Fig. 9B, left). For the majority of lobular processes, however, no colocalization could be observed despite the frequent presence of immunolabeled punctae in close proximity to these processes (Fig. 9B, right). Similar results were seen for a total of five AII amacrine cells in slices immunolabeled for GluN2B. 
For the larger dendritic trees of A17 amacrine cells, we were only able to acquire confocal image stacks, at the required resolution, of smaller portions of the total extent of these cells. Figure 9D shows an MIP of two adjacent confocal stacks with an A17 in a retinal slice immunolabeled for GluN2B. The confocal stacks were stitched together as a montage with the region of overlap running horizontally along the inner plexiform layer. In contrast to AII amacrine cells, we were not able to find any unequivocal examples of GluN2B punctae that overlapped with processes of the A17 amacrine cell when we inspected $X Y$ slices of the confocal stack (Fig. 9E). Similar results were seen for a total of three A17 amacrine cells in slices immunolabeled for GluN2B.

In parallel experiments, slices with injected AII amacrine cells were immunolabeled for the GluN2A subunit. Figure 10A shows an MIP of a confocal stack with an AII amacrine cell and immunolabeling for GluN2A. Similar to the labeling for GluN2B, the labeling for GluN2A is also punctate and is distributed across the inner plexiform layer (Hartveit et al., 1994). In contrast to the labeling for GluN2B, we were not able to find any unequivocal examples of GluN2A punctae that overlapped with processes of the AII amacrine cell when we inspected single slices $(X Y)$ of the confocal stack, both for lobular dendrites (Fig. 10B) and arboreal dendrites (Fig. 10C). While we sometimes identified apparent overlap in the $X Y$ plane, inspection of the associated $X Z$ and $Y Z$ planes indicated that the CM for the GluN2A punctum and the filled AII process were further apart and that the appearance of overlap was due to the lower resolution along the $z$ axis. Similar results were seen for a total of four AII amacrine cells in slices immunolabeled for GluN2A.

For A17 amacrine cells, however, we observed clear colocalization with GluN2A punctae. Figure $10 D$ shows an MIP of a confocal stack from a portion of an injected A17 amacrine cell in a retinal slice immunolabeled for GluN2A. Visual inspection of single slices $(X Y)$ of the confocal stack, with the two channels (A17 and GluN2A) overlaid, identified several examples of GluN2A punctae that overlapped with processes of the A17 amacrine cell (Fig. 10E). There were cases of GluN2A punctae that overlapped at putative varicosities of the A17 (Fig. $10 E$, left panels), as well as GluN2A punctae that overlapped with intervaricosity segments (Fig. $10 E$, right panels). Similar results were seen for a total of three A17 amacrine cells in slices immunolabeled for GluN2A.

\section{GluN2B is colocalized with Cx36 on AII amacrine cells}

Gap junction coupling between AII amacrine cells is mediated by Cx36 (Feigenspan et al., 2001; Mills et al., 2001; Deans et al.,
2002). There is evidence that NMDA receptors are involved in modulatory regulation of tracer coupling between AII amacrine cells, potentially via phosphorylation of $\mathrm{Cx} 36$ and a consequent increase in the junctional conductance (Kothmann et al., 2012). This predicts a close spatial association between Cx36-containing gap junction plaques and NMDA receptors with GluN2B. To investigate this, we performed double immunolabeling with antibodies against GluN2B and Cx36. Figure $11 A$ shows an MIP of a confocal stack with an injected AII amacrine cell in a retinal slice immunolabeled for both GluN2B and Cx36. Consistent with previous reports (Mills et al., 2001), immunolabeled Cx36 punctae are distributed across the inner plexiform layer, with a higher density in sublamina $b$ than in sublamina $a$ (Fig. 11A). Visual inspection of single confocal slices $(X Y)$ identified several examples of complete or partial overlap between punctae corresponding to labeling for GluN2B and $\mathrm{Cx} 36$ that also overlap with processes of the AII amacrine (Fig. 11B-E). 

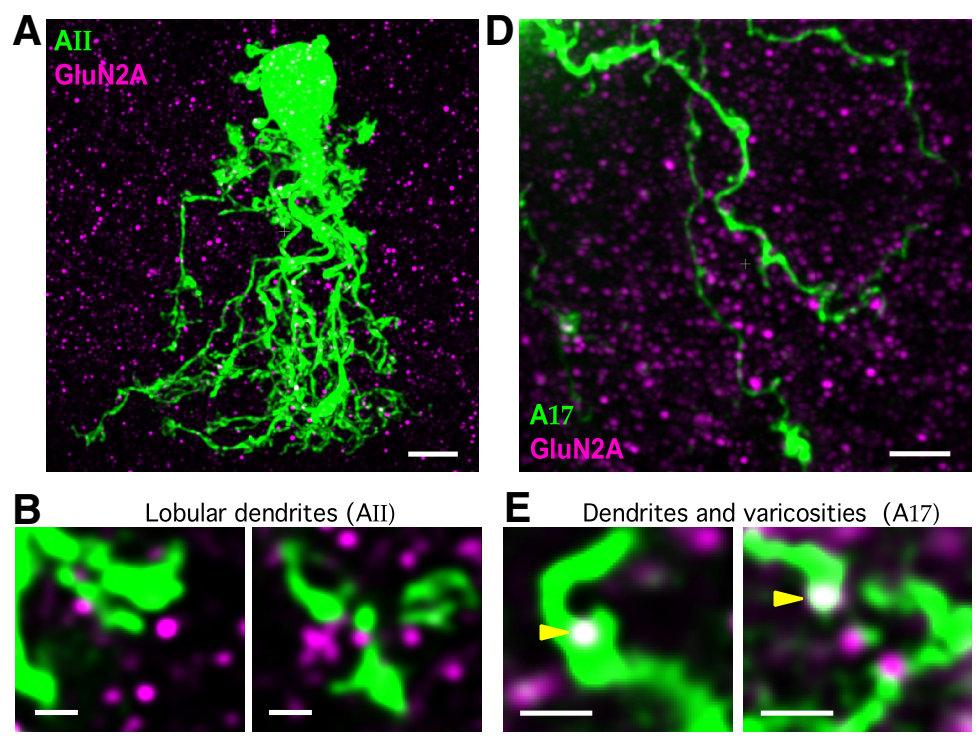

\section{$\mathrm{E}$}
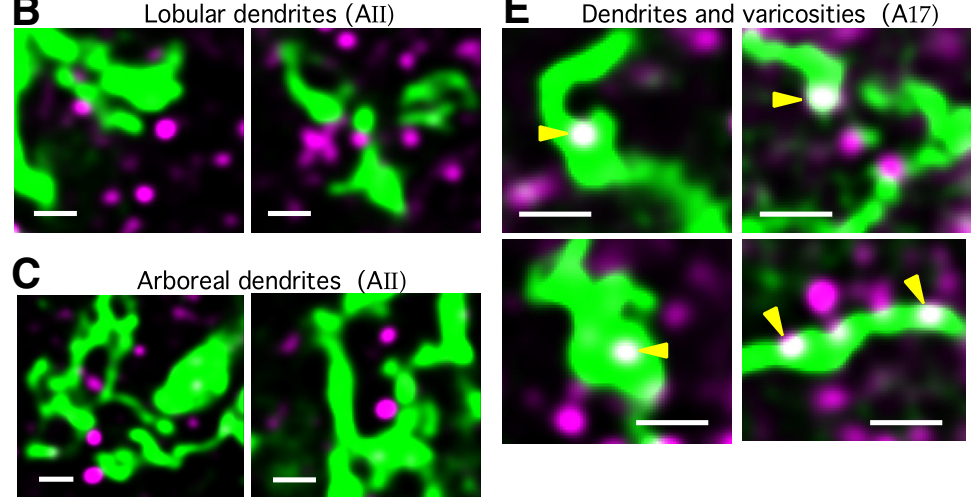

Figure 10. Colocalization between A17 (but not All) amacrine cells and immunolabeled punctae of the NMDA receptor subunit GluN2A. A, MIP of confocal image stack of retinal slice with an All amacrine cell injected with Alexa-488 (green) and immunolabeled for GluN2A (magenta). Scale bar, $10 \mu \mathrm{m}$. $\boldsymbol{A}-\boldsymbol{C}$, Images from same All amacrine. $\boldsymbol{B}$, No colocalization of GluN2A punctae (magenta) and All lobular dendrites (green) overlaid in single XY confocal slices. Scale bars, $1 \mu \mathrm{m}$. $\boldsymbol{C}$, No colocalization of GluN2A punctae (magenta) and All arboreal dendrites (green) overlaid in single XY confocal slices. Scale bars, $1 \mu \mathrm{m} . D$, MIP of confocal image stack of retinal slice with a section of processes from an A17 amacrine cell injected with Alexa-488 (green) and immunolabeled for GluN2A (magenta). Scale bar, $3 \mu \mathrm{m}$. $\boldsymbol{E}$, Examples of colocalization (arrowheads) of GluN2A punctae (magenta) and A17 dendrites (green) overlaid in single XY confocal slices. Scale bars, $1 \mu \mathrm{m} . \boldsymbol{D}, \boldsymbol{E}$, Images from same A17 amacrine, except for $\boldsymbol{E}$ (bottom right).

For a quantitative analysis, we first applied simple threshold segmentation to identify structures in the AII, GluN2B, and Cx36 channels. Following segmentation, we isolated all segmented GluN2B objects that overlapped ( $\geq 50 \%$ ) with structures belonging to the segmented AII amacrine cell. For the AII amacrine cell illustrated in Figure 11A, a total of 16 GluN2B objects overlapping with AII processes were detected (14 at the arboreals and two at the lobulars). We used the 3D (i.e., $X Y Z$ ) CM coordinates of the GluN2B punctae overlapping with the AII amacrine cell to estimate the average signal in the $\mathrm{Cx} 36$ channel. The presence of a GluN2B punctum, overlapping with the AII amacrine, resulted in a localized signal increase above background in the $\mathrm{Cx} 36$ channel (Fig. 12A,C). This strongly suggested that the presence of a GluN2B cluster associated with an AII amacrine process predicts the nearby presence of a $\mathrm{Cx} 36$ cluster corresponding to a gap junction. We repeated the analysis for $\mathrm{Cx} 36$ punctae overlapping the AII amacrine cell. We used the 3D (i.e., XYZ) CM coordinates of the Cx36 punctae overlapping ( $\geq 50 \%$ ) with the AII amacrine cell to estimate the average signal in the GluN2B channel. The presence of a Cx36 punctum, overlapping with the AII amacrine, resulted in a localized signal increase above background in the GluN2B channel (Fig. 12 B, C). Similar results were obtained for three other AII amacrine cells in slices double immunolabeled for GluN2B and Cx36. These results suggest that the GluN2Bcontaining NMDA receptors expressed by AII amacrine cells could be involved in modulating the Cx36-mediated coupling of these cells.
Activation of NMDA receptors evokes an increase of intracellular $\mathrm{Ca}^{2+}$ in both AII and A17 amacrine cells

The large relative $\mathrm{Ca}^{2+}$ permeability is a hallmark of the NMDA receptor (MacDermott et al., 1986; Mayer and Westbrook, 1987; Mayer et al., 1987). To directly investigate the putative influx of $\mathrm{Ca}^{2+}$ mediated by activation of NMDA receptors on AII and A17 amacrine cells, we loaded cells with the $\mathrm{Ca}^{2+}$ indicator OGB-1 $(200 \mu \mathrm{M})$, in addition to the $\mathrm{Ca}^{2+}$. insensitive dye Alexa-594 $(40 \mu \mathrm{M})$ for structural imaging, via diffusion from the pipette solution during whole-cell voltage-clamp recording. A total of six AII amacrine cells that were examined with $\mathrm{Ca}^{2+}$ imaging displayed stable values for $\Delta G / R$ during the baseline period. All cells displayed an electrophysiological response to application of NMDA and a clear NMDA-evoked increase in $\mathrm{Ca}^{2+}$. An example of an AII amacrine cell with a strong increase of $\mathrm{Ca}^{2+}$ is shown in Figure $13 A-C$. Figure $13 A$ shows an MIP from a complete stack of the cell acquired by structural imaging. For the focal plane used for $\mathrm{Ca}^{2+}$ imaging, a number of ROIs were selected manually and covered locations along both arboreal and lobular dendrites (including arboreal varicosities and lobular appendages), as well as the apical dendrite (Fig. 13B). For each ROI, we calculated $\Delta G / R$ as a function of time. Figure $13 C$ shows the average $\Delta G / R$ time series for ROIs at arboreal dendrites (magenta; compare Fig. 13B) and at lobular/apical dendrites (green; compare Fig. 13B). For this cell, the peak value of the average $\Delta G / R$ time series was markedly larger for arboreal ROIs (105 \pm $13 \% ; n=13$ ROIs) than for lobular/apical ROIs (28.3 $\pm 5.6 \%$; $n=7$ ROIs; unpaired $t$ test, $p=7.2 \times 10^{-5}$ ) (Fig. 13C). For all AII amacrine cells tested in this way, the corresponding values were $63 \pm 14 \%$ (range 11\%-105\%) for arboreal processes $(n=6$ cells) and $26.3 \pm 4.8 \%$ (range $12.5 \%-34.7 \%$ ) for lobular/apical processes ( $n=4$ cells; the orientation in the slice compromised simultaneous imaging of arboreal and lobular dendrites for two of the six cells). For two of the four AII cells where we obtained simultaneous measurements from ROIs along both arboreal and lobular dendrites, the NMDA-evoked $\mathrm{Ca}^{2+}$ increase (peak value of $\Delta G / R)$ was significantly higher for the arboreal than for the lobular ROIs $\left(p=9.7 \times 10^{-4}\right.$ for the cell not illustrated in Fig. 13). For the other two cells, there was no significant difference between the $\mathrm{Ca}^{2+}$ responses in the lobular and arboreal dendrites.

Similar results with NMDA-evoked increases of intracellular $\mathrm{Ca}^{2+}$ were obtained for three A17 amacrine cells tested in the same way. For the cell illustrated in Figure 13D-F, the peak increase of $\mathrm{Ca}^{2+}$ (measured as the peak $\Delta G / R$ value of the average time series for 13 ROIs) was $94 \%$. For the other two A17 cells, the corresponding values were $37 \%$ and $120 \%$. Because of the relative sparsity of processes in the single focal planes used for repeated $\mathrm{Ca}^{2+}$ imaging, it was difficult to obtain simultaneous measurements for a large number of ROIs, but we did not observe any obvious differences between the response magni- 


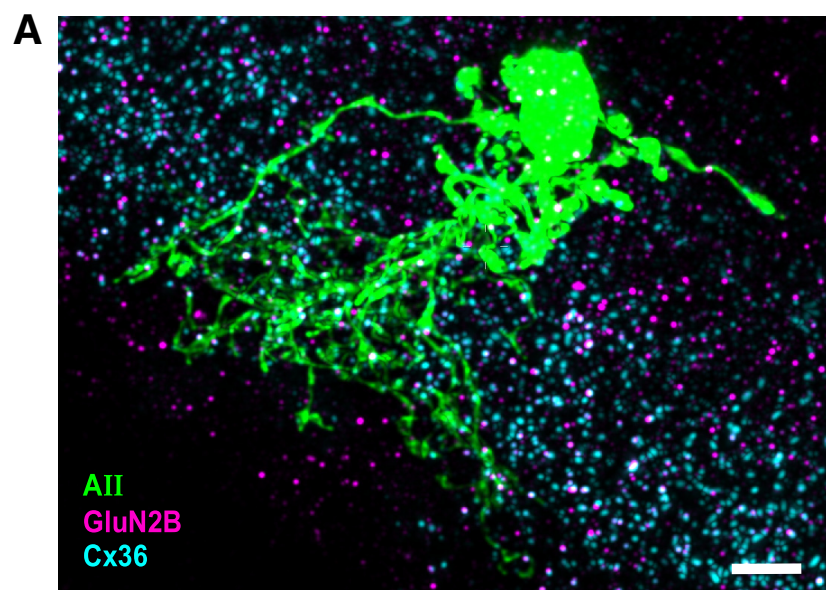

B

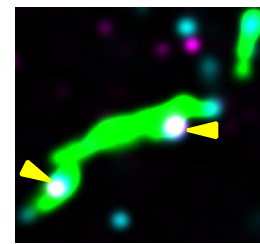

C

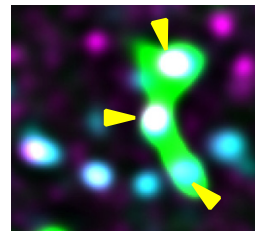

D

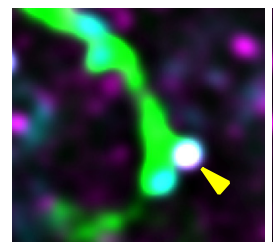

$\mathbf{E}$
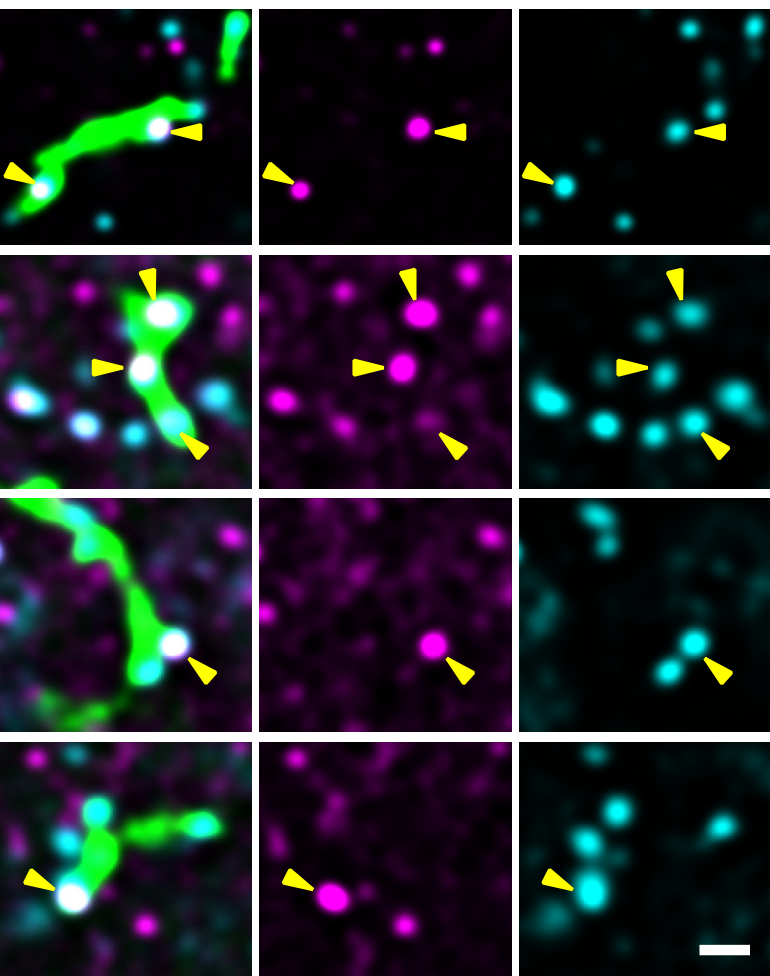

Figure 11. Colocalization between All amacrine cells, immunolabeled punctae of the NMDA receptor subunit GluN2B, and immunolabeled punctae of $C \times 36$. A, MIP of confocal image stack of retinal slice with an All amacrine cell injected with Alexa-488 (green) and immunolabeled for GluN2B (magenta) and (x36 (turqoise). Scale bar, $5 \mu \mathrm{m}$. $\boldsymbol{A}-\boldsymbol{E}$, From the same cell. $\boldsymbol{B}-\boldsymbol{E}$, Left, Examples of colocalization (arrowheads) of GluN2B punctae, (x36 punctae, and All amacrine arboreal processes. Middle, GluN2B punctae displayed alone. Right, $\mathrm{C} \times 36$ punctae displayed alone. Scale bar: $\boldsymbol{B}-\boldsymbol{E}, 1 \mu \mathrm{m}$.

tudes of ROIs located at varicosities and intervaricosity segments.

\section{NMDA receptor activation increases GABA release from A17} amacrine cells

The increase in intracellular $\mathrm{Ca}^{2+}$ following addition of NMDA suggest that the extrasynaptic NMDA receptors could serve multiple functions on both AII and A17 amacrine cells. Whereas there is evidence that both AII and A17 amacrines are homologously coupled via gap junctions (AII: Strettoi et al., 1992; Veruki and Hartveit, 2002a; A17: Xin and Bloomfield, 1997; Grimes et al., 2014), it is currently unknown whether the coupling strength between A17 amacrines is physiologically regulated, potentially
A $\mathrm{Cx36}$

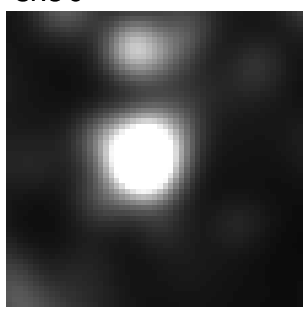

B GluN2B
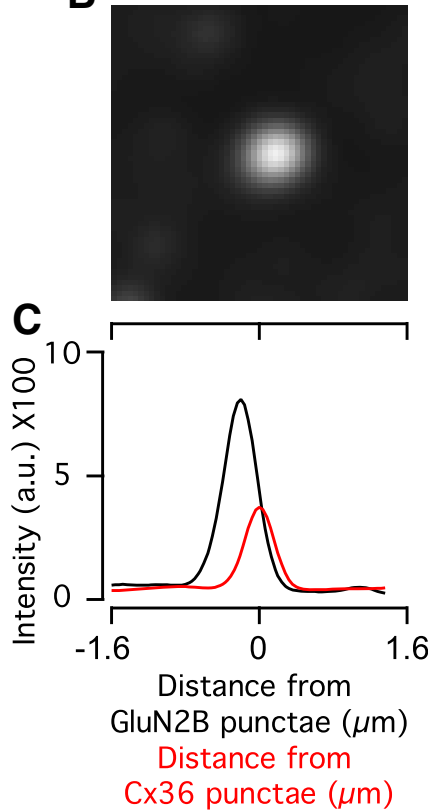

Figure 12. Colocalization analysis of GluN2B- and CX36-immunolabeled punctae overlapping with an All amacrine cell. $A$, Average signal in $\mathrm{C} \times 36$ channel around 3D coordinates (XYZ; (M) of all thresholded GluN2B punctae overlapping $\geq 50 \%$ with All amacrine cell, displayed as $2 D$ image (in $X Y$ plane) through center of extracted volume of average signal. $A, B$, Data are from the same cell as in Figure 11.2D images represent the same intensity range. $\boldsymbol{B}$, Average signal in GluN2B channel around 3D coordinates $(X Y Z ; C M)$ of all thresholded $C \times 36$ punctae overlapping $\geq 50 \%$ with All amacrine cell, displayed as $2 D$ image (in $X Y$ plane) through center of extracted volume of average signal. C, Overlaid linear intensity profiles (measured in arbitrary units, a.u.) across center of $2 D$ image in $A$ for average $C \times 36$ signal around GluN2B coordinates (black line) and across center of $2 D$ image in $\boldsymbol{B}$ for average GluN2B signal around $(x 36$ coordinates (red line).

via a mechanism involving NMDA receptors, as for AII amacrines (Kothmann et al., 2012). Instead, for A17 amacrine cells, we focused on a potential role of NMDA receptors in the control of GABA release in the feedback circuit from A17 amacrines to rod bipolar cells. We recorded from rod bipolar cells in whole-cell voltage clamp with strychnine (to block glycine receptors) and TTX (to block release from GABAergic amacrine cells with nonreciprocal input to rod bipolar cells) (Chávez et al., 2010) added to the bath solution. Any responses evoked in rod bipolar cells following application of NMDA cannot be a direct effect, as we have previously demonstrated that rod bipolar cells do not express NMDA receptors (Zhou et al., 2016).

The rod bipolar cell illustrated in Figure $14 A$ displayed a low frequency of spontaneous IPSCs in the control condition $(\sim 0.1$ $\mathrm{Hz}$ ). The amplitude of the average IPSC in the control condition was $5.6 \mathrm{pA}(n=9$ events recorded during $90 \mathrm{~s}$; Fig. $14 B)$. When we added NMDA $(50 \mu \mathrm{M})$ to the bath solution, the frequency of IPSCs markedly increased to $\sim 2.8 \mathrm{~Hz}$ (Fig. 14A). The amplitude of the average IPSC in the presence of NMDA was $5.4 \mathrm{pA}(n=$ 252 events recorded during $90 \mathrm{~s}$; Fig. 14B), very similar to that in 

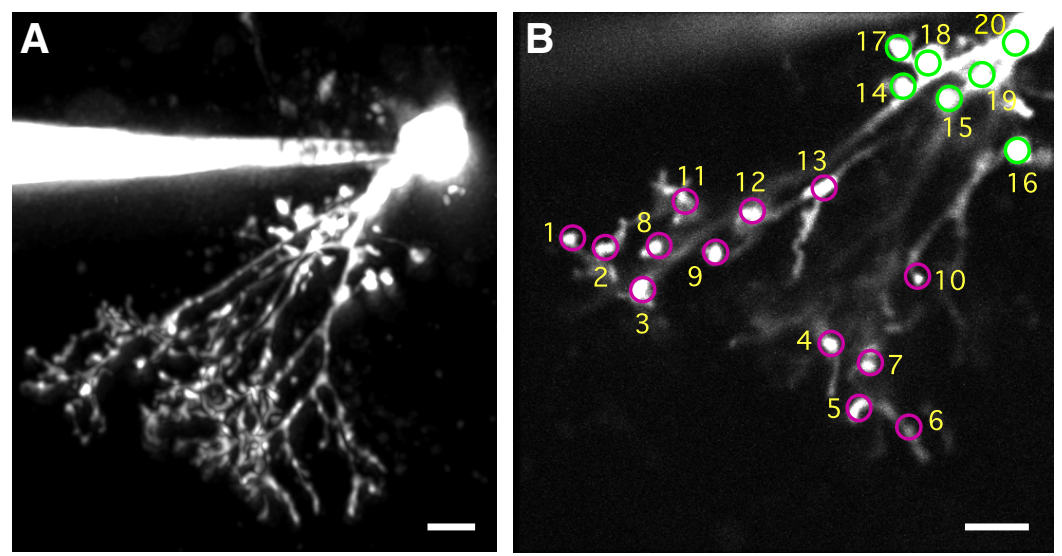

C
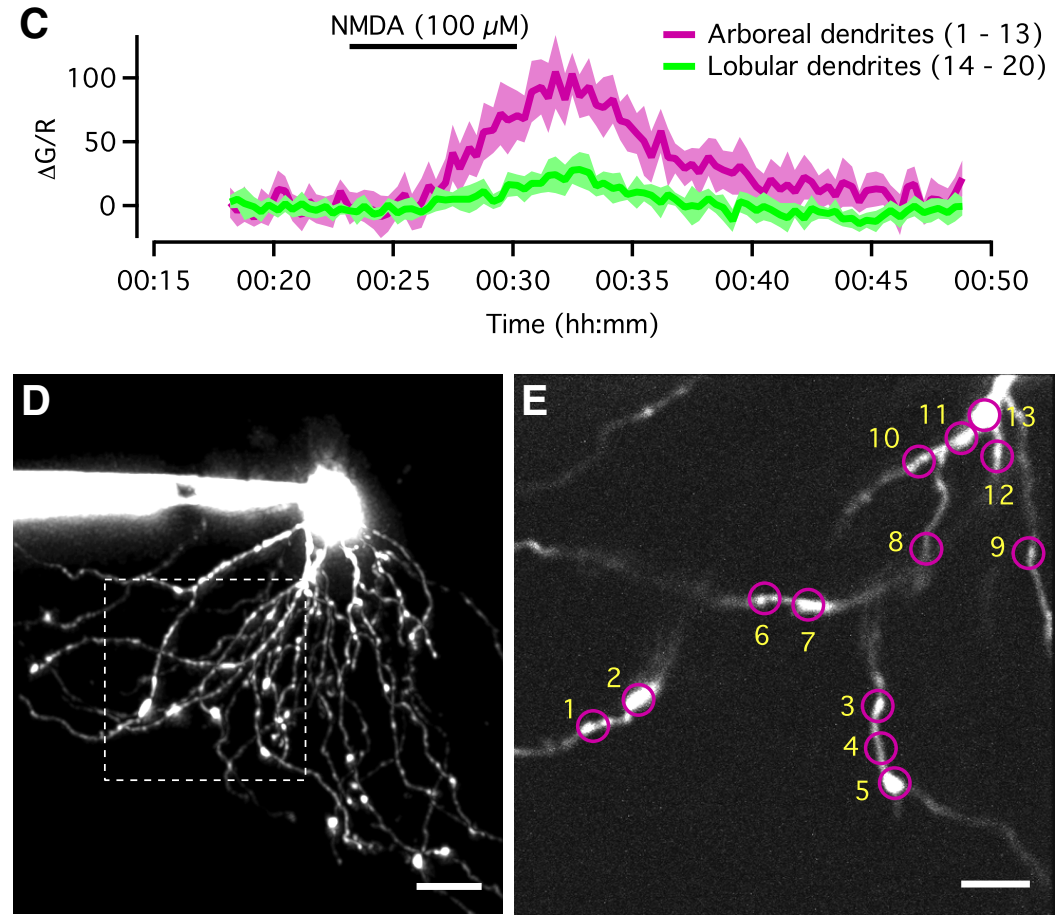

$\mathbf{F}$

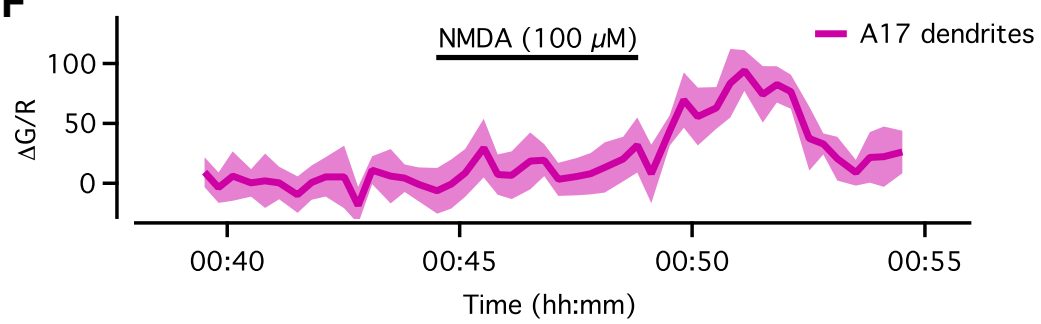

Figure 13. NMDA receptor activation increases intracellular $\mathrm{Ca}^{2+}$ in All and $\mathrm{A} 17$ amacrine cells. $A$, All amacrine cell filled with Alexa594 via patch pipette. MIP (along z axis) generated from MPE fluorescence image stack. Scale bar, $5 \mu \mathrm{m}$. B, Same cell as in $\boldsymbol{A}$, image from single focal plane in a smaller subregion of $\boldsymbol{A}$, generated by averaging all images of Alexa-594 fluorescence acquired during time period displayed in C. Magenta and green circles indicate ROIs in arboreal (ROI1-ROI13) and lobular (RO114-RO120) dendrites, respectively, used for calculating changes in intracellular $\mathrm{Ca}^{2+}$. Scale bar, $5 \mu \mathrm{m} . \mathrm{C}_{,} \mathrm{Ca}^{2+}$ signals in arboreal and lobular dendrites (averaged over corresponding ROIs in $\boldsymbol{B}$ ) evoked by bath application of NMDA ( $100 \mu \mathrm{m}$; marked by the continuous horizontal line above data traces). Here and in $\boldsymbol{F}, \mathrm{Ca}^{2+}$ signal calculated as $\Delta G / R$, i.e., the change in OGB-1 (green; G) fluorescence normalized by the change in Alexa-594 (red; $R$ ) fluorescence. Each trace represents the average for all corresponding arboreal (magenta) and lobular (green) ROls in $\boldsymbol{B}$. Shaded area represents $\pm 95 \% \mathrm{Cl}$. Here and in $\boldsymbol{F}$, time 0 corresponds to breaking into the cell and establishing the whole-cell recording configuration. $\boldsymbol{D}, \mathrm{A} 17$ amacrine cell filled with Alexa-594 via patch pipette. MIP (along $z$ axis) generated from MPE fluorescence image stack. Scale bar, $10 \mu \mathrm{m}$. Dashed rectangle represents the region used for $\mathrm{Ca}^{2+}$ imaging (in $\boldsymbol{E}$ ). $\boldsymbol{E}$, Same cell as in $\boldsymbol{D}$, image from single focal plane, generated by averaging all images of Alexa-594 fluorescence acquired during time period displayed in $F$. Circles represent ROIs in dendritic tree, used for calculating changes in intracellular $\mathrm{Ca}^{2+}$. Scale bar, $5 \mu \mathrm{m} . \boldsymbol{F}, \mathrm{Ca}^{2+}$ signal in $\mathrm{A} 17$ dendrites (averaged over corresponding ROls in $E$ ) evoked by bath application of NMDA (100 $\mu$; marked by the continuous horizontal line above data trace). Trace represents the average for all ROls in $\boldsymbol{E}$. Shaded area represents $\pm 95 \% \mathrm{Cl}$. the control condition. For a total of five rod bipolar cells, the average IPSC frequency increased from $0.19 \pm 0.08 \mathrm{~Hz}$ in the control condition to $2.14 \pm 0.51 \mathrm{~Hz}$ during application of NMDA $(p=0.015$, paired $t$ test; Fig. $14 C$ ). There was no statistically significant difference in the amplitude of the average IPSC between the control condition $(5.0 \pm 0.3 \mathrm{pA})$ and during application of NMDA $(5.4 \pm 0.5 \mathrm{pA})$ ( $p=0.10$, paired $t$ test; $n=4$ cells; Fig. 14D). One cell did not display IPSCs in the control condition and was excluded from the amplitude analysis. When we repeated the application of NMDA in the presence of bicuculline $(10 \mu \mathrm{M})$ and TPMPA (50 $\mu \mathrm{M})$ to block $\mathrm{GABA}_{\mathrm{A}}$ and $\mathrm{GABA}_{\mathrm{C}}$ receptors, respectively (in addition to strychnine and TTX), there were no IPSCs in the control condition and no IPSCs were evoked after adding NMDA ( $n=3$ cells; Fig. 14E). These results suggested that the IPSCs were mediated by ionotropic $\mathrm{GABA}_{\mathrm{A}}$ and/or $\mathrm{GABA}_{\mathrm{C}}$ receptors and that NMDA receptors on A17 amacrine cells can contribute to release of GABA from these cells.

\section{Discussion}

We have found that the NMDA receptors expressed by the amacrine cells in the rod bipolar cell-AII-A17 microcircuit are exclusively extrasynaptic and tonically activated by ambient glutamate. In addition, their activation leads to an increase of intracellular $\mathrm{Ca}^{2+}$ in both cell types and can drive release of GABA from A17 amacrines onto rod bipolar cells. Whereas both amacrines express diheteromeric NMDA receptors, AII and A17 amacrines incorporate different and complementary GluN2 subunits. Specifically, AIIs express GluN2B-containing receptors and A17s express GluN2A-containing receptors. Below, we discuss the basis for these interpretations and their functional implications.

\section{Identity of NMDA receptors on AII and} A17 amacrine cells

The GluN2 subunits strongly influence the functional properties of NMDA receptors, including single-channel conductance, open probability, affinity for glutamate and coagonists, kinetics, $\mathrm{Mg}^{2+}$ sensitivity, and $\mathrm{Ca}^{2+}$ permeability (Paoletti et al., 2013). On this background, evidence for differential expression and involvement of GluN2 subunits in various processes in the developing, adult, and diseased nervous system has triggered considerable interest in pharmacological tools to dissect the 
A

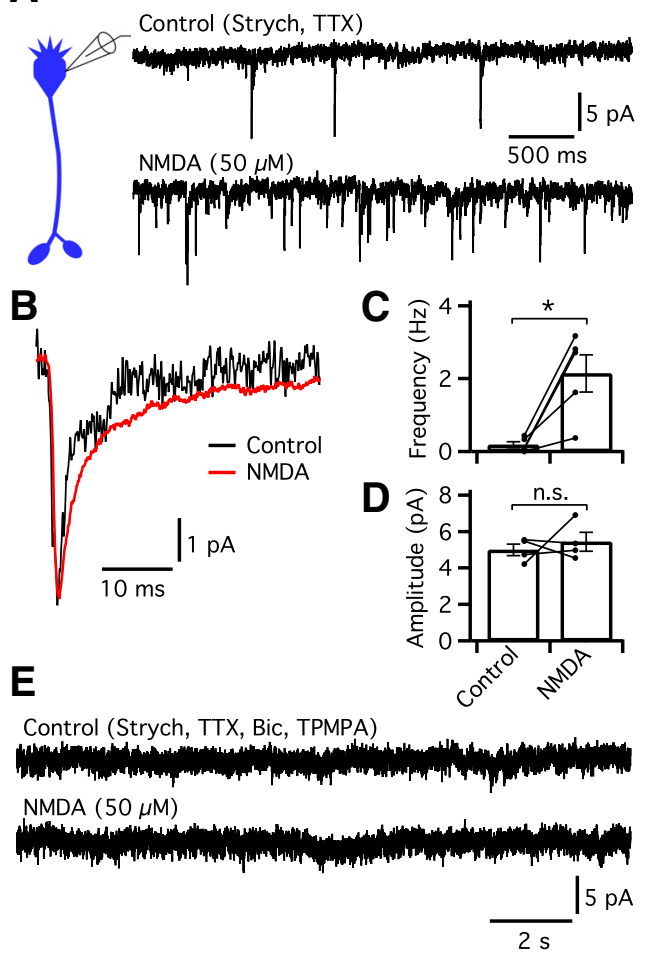

Figure 14. Activation of NMDA receptors on presumed A17 amacrine cells increases GABAergic input to rod bipolar cells. $A$, Continuous current recorded from a rod bipolar cell $\left(V_{\text {hold }}=\right.$ $-60 \mathrm{mV}$ ) in control condition (top) and during bath application of NMDA (50 $\mu \mathrm{m}$; bottom). The equilibrium potential for chloride $\left(E_{C}\right)$ was $\sim 0 \mathrm{mV}$, such that responses mediated by activation of ionotropic GABA receptors appear as inward currents when $V_{\text {hold }}=-60 \mathrm{mV}$. In both conditions (here and in $\boldsymbol{E}$ ), the bath solution contained strychnine ( $300 \mathrm{~nm}$; to block glycine receptors) and TTX (300 nm; to block voltage-gated $\mathrm{Na}^{+}$channels) and the pipette solution contained TBOA (50 $\mu \mathrm{m}$; to block glutamate transporter activity). NMDA was added with 200 $\mu \mathrm{M}$ D-serine, to saturate the coagonist binding site, and $0 \mathrm{Mg}^{2+}$, to alleviate the voltagedependent block. Note the increased frequency of IPSCs in the presence of NMDA. $\boldsymbol{B}$, Averaged waveforms of IPSCs in the control condition (black trace; $n=9$ events detected during $90 \mathrm{~s}$ recording) and in the presence of NMDA (red trace; $n=252$ events detected during $90 \mathrm{~s}$ recording). C, Frequency of IPSCs in rod bipolar cells ( $n=5$ cells) in the control condition (left bar) and in the presence of NMDA (50 $\mu \mathrm{m}$; right bar). $\boldsymbol{D}$. Amplitude of average IPSCs in rod bipolar cells (same cells as in $C$ ) in the control condition (left bar) and in the presence of NMDA ( $50 \mu \mathrm{m}$; right bar). $\boldsymbol{E}$, Continuous current recorded from a rod bipolar cell in control condition (top; as in $A$ ) and during bath application of NMDA ( $50 \mu \mathrm{m}$; bottom; as in $A$ ). In both conditions, the bath solution also contained bicuculline ( $10 \mu \mathrm{m}$; to block $\mathrm{GABA}_{\mathrm{A}}$ receptors) and TPMPA (50 $\mu \mathrm{m}$; to block $\mathrm{GABA}_{\mathrm{c}}$ receptors). Note the absence of IPSCs both in control and during application of NMDA. Statistical comparisons between averages: n.s., No significant difference $(p>0.05)$. ${ }^{*} p<0.05$.

contribution of specific GluN2 subunits to distinct neural functions. Using antagonists that display strong selectivity for either GluN2Aor GluN2B-containing receptors, we found GluN2A-containing receptors on A17, but not AII amacrines, and GluN2Bcontaining receptors on AII, but not A17 amacrines. We found no evidence for GluN2C/D receptors or triheteromeric NMDA receptors in either cell type. Whereas there is evidence for expression of the GluN3A subunit in retina (Sucher et al., 2003), the functional properties of GluN3-containing NMDA receptors are markedly different from GluN2A/B-containing receptors, including very weak sensitivity to $\mathrm{Mg}^{2+}$ and reduced $\mathrm{Ca}^{2+}$ permeability (Henson et al., 2010; Pachernegg et al., 2012). NMDA receptors in AII and A17 amacrines display clear sensitivity to $\mathrm{Mg}^{2+}$ (Zhou et al., 2016), suggesting that it is unlikely that GluN3-containing receptors represent a substantial fraction of the receptors in these cells. Our pharmacological experiments strongly suggest the presence of diheteromeric NMDA receptors in both amacrines, with GluN2B-containing receptors in AII amacrines and GluN2A-containing receptors in A17 amacrines. These conclusions are further supported by immunolabeling of GluN2A and GluN2B subunits in slices with dye-filled AII and A17 amacrines. GluN2B punctae were localized to the processes of AII amacrines, predominantly on arboreal dendrites. GluN2A punctae were detected on the processes of A17 amacrines both at and between varicosities. An important next step will be to extend these results using super-resolution microscopy, potentially combined with immunolabeling of presynaptic and postsynaptic proteins to investigate the detailed spatial relationships between these extrasynaptic NMDA receptors and neighboring chemical and electrical synapses.

\section{Functional role of GluN2A- and GluN2B-containing NMDA} receptors in AII and A17 amacrine cells

It has been suggested that GluN2A-containing receptors primarily have a synaptic location (e.g., Dalby and Mody, 2003), whereas GluN2B-containing receptors primarily have an extrasynaptic location and are strategically positioned to detect extrasynaptic spillover of glutamate (e.g., Scimemi et al., 2004). Whereas this arrangement has been observed in some retinal ganglion cells (Zhang and Diamond, 2009), our recordings of synaptically connected pairs of rod bipolar and amacrine cells suggest that both GluN2B- and GluN2A-containing NMDA receptors have an extrasynaptic localization on AII and A17 amacrine cells, respectively. Additionally, our observation of CPP-sensitive membrane noise in both amacrines suggests that endogenous glutamate is sufficiently high to activate these NMDA receptors. Extrasynaptic NMDA receptors contribute to baseline membrane noise in other neurons, including hippocampal pyramidal cells (Sah et al., 1989; Le Meur et al., 2007) and retinal ganglion cells (Gottesman and Miller, 2003). Although our estimate of the unitary conductance of the NMDA receptors in AII amacrine cells is lower than observed in singlechannel recordings of GluN2A- and GluN2B-containing receptors in isolated membrane patches $(40-50 \mathrm{pS}$ ) (CullCandy and Leszkiewicz, 2004), it is significantly higher than previous reports from noise analysis of neuronal whole-cell recordings (e.g., Sah et al., 1989). This is potentially explained by relatively less electrotonic filtering of membrane noise in AII amacrines, consistent with their smaller size.

Whereas synaptic NMDA receptors on ganglion cells have been implicated in mediating light-evoked responses and neural computations involved in contrast sensitivity, temporal coding, and directional selectivity (Manookin et al., 2010; Jones et al., 2012; Stafford et al., 2014; Poleg-Polsky and Diamond, 2016), the role of NMDA receptors on amacrine cells, including the AII and A17, is unclear. In general, activation of extrasynaptic NMDA receptors has been associated with neurodegenerative diseases (Parsons and Raymond, 2014). It has been demonstrated that amacrine cells, compared with ganglion cells, display a specific vulnerability to NMDA excitotoxicity (Ullian et al., 2004); thus, the extrasynaptic location of these NMDA receptors may suggest a potential target in glutamate-associated retinal degeneration. However, a crucial question raised by our results concerns the functional significance of the different subunit composition (GluN2A vs GluN2B), as opposed to a differential localization (synaptic vs extrasynaptic), of the NMDA receptors expressed by AII and A17 amacrine cells. Reported differences between the functional properties of GluN2A- and GluN2B-containing NMDA receptors may be relevant for their specific role in the network 
computations performed by AII and A17 amacrine cells. Compared with GluN2A-containing receptors, GluN2B-containing receptors have higher macroscopic affinity for glutamate and glycine (Kutsuwada et al., 1992), lower open probability (Erreger et al., 2005), and slower kinetics (Monyer et al., 1994; Vicini et al., 1998). Whereas both subunits give rise to NMDA receptors with high relative $\mathrm{Ca}^{2+}$ permeability (Monyer et al., 1992, 1994), activation of GluN2B-containing receptors can generate longer, slower, and potentially larger $\mathrm{Ca}^{2+}$ signals than activation of GluN2A-containing receptors (Erreger et al., 2005). These differences have been speculated to underlie differences in synaptic plasticity, with fast, larger-amplitude signals inducing potentiation and slow, lower-amplitude signals inducing depression (Liu et al., 2004). Such subunitdependent properties, identified above for different receptors on the same cells, might be exploited for different purposes when the receptors are expressed by neurons with very different morphological and functional properties, such as the AII and $\mathrm{A} 17$ amacrine cells. If the complementary content of GluN2B and GluN2A subunits in the NMDA receptors of AII and A17 amacrines is important for differentially shaping the temporal concentration profiles of $\mathrm{Ca}^{2+}$ signals in specific subcellular compartments of these two cells, the functional role of such signals is by no means obvious.

For AII amacrines, there is evidence that the extrasynaptic NMDA receptors could be involved in modulating the strength of gap junction coupling between these cells (Kothmann et al., 2012). If so, our results suggest that GluN2B-containing NMDA receptors are involved in such modulation, as the GluN2B punctae on AII amacrines have a close spatial relationship with Cx36 punctae on these same cells. The physiological conditions that lead to modulation of coupling strength remain to be fully explored, but there is evidence that the adaptational state of the retina affects the extent of coupling between AII amacrines (Bloomfield et al., 1997). For A17 amacrines, there is evidence that synaptic release of GABA can be directly triggered by $\mathrm{Ca}^{2+}$ influx through $\mathrm{Ca}^{2+}$-permeable AMPA receptors (Chávez et al., 2006) as well as by depolarization and activation of voltage-gated $\mathrm{Ca}^{2+}$ channels (Grimes et al., 2009). Our results suggest that GluN2A-containing NMDA receptors can also contribute to the release of GABA, but it is unknown whether NMDA receptor activation will drive release via activation of voltage-gated $\mathrm{Ca}^{2+}$ channels or direct coupling of the $\mathrm{Ca}^{2+}$ influx through the NMDA receptors to exocytosis (or both). It is of interest that a mechanism with direct coupling between NMDA receptormediated $\mathrm{Ca}^{2+}$ influx and release of GABA has been observed for synapses between granule cells and mitral cells in the olfactory bulb (Chen et al., 2000). In goldfish retina, the release of GABA from amacrine cells providing reciprocal feedback to bipolar cells can be driven by NMDA receptors, but the mechanism that couples receptor activation to release is unknown (Vigh and von Gersdorff, 2005). For the NMDA receptors on both AII and A17 amacrines, an important next step will be to investigate the physiological conditions under which the voltage-dependent $\mathrm{Mg}^{2+}$ block is relieved. In addition, it will be important to investigate whether potential fluctuations in the concentrations of NMDA receptor coagonist(s) can play a role in the activation of these receptors.

In addition to the possibility that differences in subunit composition between NMDA receptors on AII and A17 amacrines could generate temporally distinct $\mathrm{Ca}^{2+}$ signals and trigger different intracellular signal transduction pathways, the molecular differences between GluN2A and GluN2B sub- units as such could be of functional importance. There is evidence that GluN2A and GluN2B subunits associate with distinct proteins, including signaling enzymes (e.g., CaMKII) and scaffolding proteins (e.g., SAP102 and PSD-95) (for review, see Shipton and Paulsen, 2013). A recent immunolabeling study suggested a differential distribution of CaMKII isoforms in the inner plexiform layer, with CaMKII- $\delta$ associated with Cx36 on AII amacrine cells and CaMKII- $\beta$ associated with neuronal processes surrounding rod bipolar cell axon terminals (Tetenborg et al., 2017). It is tempting to speculate that these processes might include those of A17 amacrine cells. Further work will be required to elucidate the potential importance of such channel-associated proteins for NMDA receptor signaling in AII and A17 amacrine cells.

\section{References}

Acker TM, Yuan H, Hansen KB, Vance KM, Ogden KK, Jensen HS, Burger PB, Mullasseril P, Snyder JP, Liotta DC, Traynelis SF (2011) Mechanism for noncompetitive inhibition by novel GluN2C/D N-methyl-D-aspartate receptor subunit-selective modulators. Mol Pharmacol 80:782-795. CrossRef Medline

Asztely F, Erdemli G, Kullmann DM (1997) Extrasynaptic glutamate spillover in the hippocampus: dependence on temperature and the role of active glutamate uptake. Neuron 18:281-293. CrossRef Medline

Bloomfield SA, Xin D, Osborne T (1997) Light-induced modulation of coupling between AII amacrine cells in the rabbit retina. Vis Neurosci 14:565576. CrossRef Medline

Boos R, Schneider H, Wässle H (1993) Voltage- and transmitter-gated currents of AII-amacrine cells in a slice preparation of the rat retina. J Neurosci 13:2874-2888. CrossRef Medline

Brandstätter JH, Hartveit E, Sassoè-Pognetto M, Wässle H (1994) Expression of NMDA and high-affinity kainate receptor subunit mRNAs in the adult rat retina. Eur J Neurosci 6:1100-1112. CrossRef Medline

Buldyrev I, Puthussery T, Taylor WR (2012) Synaptic pathways that shape the excitatory drive in an OFF retinal ganglion cell. J Neurophysiol 107: 1795-1807. CrossRef Medline

Castilho Á, Ambrósio AF, Hartveit E, Veruki ML (2015) Disruption of a neural microcircuit in the rod pathway of the mammalian retina by diabetes mellitus. J Neurosci 35:5422-5433. CrossRef Medline

Cavelier P, Hamann M, Rossi D, Mobbs P, Attwell D (2005) Tonic excitation and inhibition of neurons: ambient transmitter sources and computational consequences. Prog Biophys Mol Biol 87:3-16. CrossRef Medline

Chávez AE, Singer JH, Diamond JS (2006) Fast neurotransmitter release triggered by Ca influx through AMPA-type glutamate receptors. Nature 443:705-708. CrossRef Medline

Chávez AE, Grimes WN, Diamond JS (2010) Mechanisms underlying lateral GABAergic feedback onto rod bipolar cells in rat retina. J Neurosci 30:2330-2339. CrossRef Medline

Chen S, Diamond JS (2002) Synaptically released glutamate activates extrasynaptic NMDA receptors on cells in the ganglion cell layer of rat retina. J Neurosci 22:2165-2173. CrossRef Medline

Chen WR, Xiong W, Shepherd GM (2000) Analysis of relations between NMDA receptors and GABA release at olfactory bulb reciprocal synapses. Neuron 25:625-633. CrossRef Medline

Ciolofan C, Li XB, Olson C, Kamasawa N, Gebhardt BR, Yasumura T, Morita M, Rash JE, Nagy JI (2006) Association of connexin36 and zonula occludens- 1 with zonula occludens- 2 and the transcription factor zonula occludens-1-associated nucleic acid-binding protein at neuronal gap junctions in rodent retina. Neuroscience 140:433-451. CrossRef Medline

Cull-Candy SG, Leszkiewicz DN (2004) Role of distinct NMDA receptor subtypes at central synapses. Sci STKE 2004:re16. CrossRef Medline

Dalby NO, Mody I (2003) Activation of NMDA receptors in rat dentate gyrus granule cells by spontaneous and evoked transmitter release. J Neurophysiol 90:786-797. CrossRef Medline

Danbolt NC (2001) Glutamate uptake. Prog Neurobiol 65:1-105. CrossRef Medline

Deans MR, Völgyi B, Goodenough DA, Bloomfield SA, Paul DL (2002) Connexin 36 is essential for transmission of rod-mediated visual signals in the mammalian retina. Neuron 36:703-712. CrossRef Medline 
Demb JB, Singer JH (2012) Intrinsic properties and functional circuitry of the AII amacrine cell. Vis Neurosci 29:51-60. CrossRef Medline

Diamond JS, Grimes WN (2014) Distributed parallel processing in retinal amacrine cells. In: The computing dendrite: from structure to function (Cuntz H, Remme MW, Torben-Nielsen B, eds), pp 191-204. New York: Springer.

Dorostkar MM, Dreosti E, Odermatt B, Lagnado L (2010) Computational processing of optical measurements of neuronal and synaptic activity in networks. J Neurosci Methods 188:141-150. CrossRef Medline

Erreger K, Dravid SM, Banke TG, Wyllie DJ, Traynelis SF (2005) Subunitspecific gating controls rat NR1/NR2A and NR1/NR2B NMDA channel kinetics and synaptic signalling profiles. J Physiol 563:345-358. CrossRef Medline

Fayyazuddin A, Villarroel A, Le Goff A, Lerma J, Neyton J (2000) Four residues of the extracellular N-terminal domain of the NR2A subunit control high-affinity $\mathrm{Zn}^{2+}$ binding to NMDA receptors. Neuron 25:683694. CrossRef Medline

Feigenspan A, Teubner B, Willecke K, Weiler R (2001) Expression of neuronal connexin36 in AII amacrine cells of the mammalian retina. J Neurosci 21:230-239. CrossRef Medline

Fischer G, Mutel V, Trube G, Malherbe P, Kew JN, Mohacsi E, Heitz MP, Kemp JA (1997) Ro 25-6981, a highly potent and selective blocker of $\mathrm{N}$-methyl-D-aspartate receptors containing the NR2B subunit. Characterization in vitro. J Pharmacol Exp Ther 283:1285-1292. Medline

Fletcher EL, Hack I, Brandstätter JH, Wässle H (2000) Synaptic localization of NMDA receptor subunits in the rat retina. J Comp Neurol 420:98-112. CrossRef Medline

Frizelle PA, Chen PE, Wyllie DJ (2006) Equilibrium constants for $(R)-[(S)$ 1-(4-bromo-phenyl)-ethylamino]-(2,3-dioxo-1,2,3,4-tetrahydroquin oxalin-5-yl)-methyl]-phosphonic acid (NVP-AAM077) acting at recombinant NR1/NR2A and NR1/NR2B N-methyl-D-aspartate receptors: implications for studies of synaptic transmission. Mol Pharmacol 70:1022-1032. CrossRef Medline

Gottesman J, Miller RF (2003) N-methyl-D-aspartate receptors contribute to the baseline noise of retinal ganglion cells. Vis Neurosci 20:329-333. CrossRef Medline

Graydon CW, Lieberman EE, Rho N, Briggman KL, Singer JH, Diamond JS (2018) Synaptic transfer between rod and cone pathways mediated by AII amacrine cells in the mouse retina. Curr Biol 28:2739-2751.e3. CrossRef Medline

Grimes WN, Li W, Chávez AE, Diamond JS (2009) BK channels modulate pre- and postsynaptic signaling at reciprocal synapses in retina. Nat Neurosci 12:585-592. CrossRef Medline

Grimes WN, Hoon M, Briggman KL, Wong RO, Rieke F (2014) Crosssynaptic synchrony and transmission of signal and noise across the mouse retina. eLife 3:e03892. CrossRef Medline

Hansen KB, Traynelis SF (2011) Structural and mechanistic determinants of a novel site for noncompetitive inhibition of GluN2D-containing NMDA receptors. J Neurosci 31:3650-3661. CrossRef Medline

Hansen KB, Ogden KK, Yuan H, Traynelis SF (2014) Distinct functional and pharmacological properties of triheteromeric GluN1/GluN2A/ GluN2B NMDA receptors. Neuron 81:1084-1096. CrossRef Medline

Hartveit E (1999) Reciprocal synaptic interactions between rod bipolar cells and amacrine cells in the rat retina. J Neurophysiol 81:2923-2936. CrossRef Medline

Hartveit E, Veruki ML (1997) AII amacrine cells express functional NMDA receptors. Neuroreport 8:1219-1223. CrossRef Medline

Hartveit E, Brandstätter JH, Sassoè-Pognetto M, Laurie DJ, Seeburg PH, Wässle H (1994) Localization and developmental expression of the NMDA receptor subunit NR2A in the mammalian retina. J Comp Neurol 348:570-582. CrossRef Medline

Hartveit E, Zandt B-J, Madsen E, Castilho Á, Mørkve SH, Veruki ML (2018) AMPA receptors at ribbon synapses in the mammalian retina: kinetic models and molecular identity. Brain Struct Funct 223:769-804. CrossRef Medline

Hatton CJ, Paoletti P (2005) Modulation of triheteromeric NMDA receptors by N-terminal domain ligands. Neuron 46:261-274. CrossRef Medline

Henson MA, Roberts AC, Pérez-Otaño I, Philpot BD (2010) Influence of the NR3A subunit on NMDA receptor functions. Prog Neurobiol 91:2337. CrossRef Medline

Hilgen G, von Maltzahn J, Willecke K, Weiler R, Dedek K (2011) Subcellular distribution of connexin 45 in OFF bipolar cells of the mouse retina. J Comp Neurol 519:433-450. CrossRef Medline

Huettner JE, Bean BP (1988) Block of N-methyl-D-aspartate-activated current by the anticonvulsant MK-801: selective binding to open channels. Proc Natl Acad Sci U S A 85:1307-1311. CrossRef Medline

Ichinose T, Lukasiewicz PD (2012) The mode of retinal presynaptic inhibition switches with light intensity. J Neurosci 32:4360-4371. CrossRef Medline

Isaacson JS, Murphy GJ (2001) Glutamate-mediated extrasynaptic inhibition: direct coupling of NMDA receptors to $\mathrm{Ca}^{2+}$-activated $\mathrm{K}^{+}$channels. Neuron 31:1027-1034. CrossRef Medline

Jones RS, Carroll RC, Nawy S (2012) Light-induced plasticity of synaptic AMPA receptor composition in retinal ganglion cells. Neuron 75:467478. CrossRef Medline

Kew JN, Trube G, Kemp JA (1996) A novel mechanism of activitydependent NMDA receptor antagonism describes the effect of ifenprodil in rat cultured cortical neurones. J Physiol 497:761-772. CrossRef Medline

Kleckner NW, Dingledine R (1988) Requirement for glycine in activation of NMDA- receptors expressed in Xenopus oocytes. Science 241:835-837. CrossRef Medline

Kothmann WW, Trexler EB, Whitaker CM, Li W, Massey SC, O'Brien J (2012) Nonsynaptic NMDA receptors mediate activity-dependent plasticity of gap junctional coupling in the AII amacrine cell network. J Neurosci 32:6747-6759. CrossRef Medline

Kutsuwada T, Kashiwabuchi N, Mori H, Sakimura K, Kushiya E, Araki K, Meguro H, Masaki H, Kumanishi T, Arakawa M (1992) Molecular diversity of the NMDA receptor channel. Nature 358:36-41. CrossRef Medline

Le Meur K, Galante M, Angulo MC, Audinat E (2007) Tonic activation of NMDA receptors by ambient glutamate of non-synaptic origin in the rat hippocampus. J Physiol 580:373-383. CrossRef Medline

Liu L, Wong TP, Pozza MF, Lingenhoehl K, Wang Y, Sheng M, Auberson YP, Wang YT (2004) Role of NMDA receptor subtypes in governing the direction of hippocampal synaptic plasticity. Science 304:1021-1024. CrossRef Medline

MacDermott AB, Mayer ML, Westbrook GL, Smith SJ, Barker JL (1986) NMDA-receptor activation increases cytoplasmic calcium concentration in cultured spinal cord neurones. Nature 321:519-522. CrossRef Medline

Manookin MB, Weick M, Stafford BK, Demb JB (2010) NMDA receptor contributions to visual contrast coding. Neuron 67:280-293. CrossRef Medline

Mayer ML, Westbrook GL (1987) Permeation and block of N-methyl-Daspartic acid receptor channels by divalent cations in mouse cultured central neurones. J Physiol 394:501-527. CrossRef Medline

Mayer ML, MacDermott AB, Westbrook GL, Smith SJ, Barker JL (1987) Agonist- and voltage-gated calcium entry in cultured mouse spinal cord neurons under voltage clamp measured using arsenazo III. J Neurosci 7:3230-3244. CrossRef Medline

Menger N, Wässle H (2000) Morphological and physiological properties of the A17 amacrine cell in the rat retina. Vis Neurosci 17:769-780. CrossRef Medline

Meyer A, Tetenborg S, Greb H, Segelken J, Dorgau B, Weiler R, Hormuzdi SG, Janssen-Bienhold U, Dedek K (2016) Connexin30.2: in vitro interaction with connexin36 in HeLa cells and expression in AII amacrine cells and intrinsically photosensitive ganglion cells in the mouse retina. Front Mol Neurosci 9:36. CrossRef Medline

Mills SL, O’Brien JJ, Li W, O’Brien J, Massey SC (2001) Rod pathways in the mammalian retina use connexin 36. J Comp Neurol 436:336-350. CrossRef Medline

Monyer H, Sprengel R, Schoepfer R, Herb A, Higuchi M, Lomeli H, Burnashev N, Sakmann B, Seeburg PH (1992) Heteromeric NMDA receptors: molecular and functional distinction of subtypes. Science 256:1217-1221. CrossRef Medline

Monyer H, Burnashev N, Laurie DJ, Sakmann B, Seeburg PH (1994) Developmental and regional expression in the rat brain and functional properties of four NMDA receptors. Neuron 12:529-540. CrossRef Medline

Moore-Dotson JM, Beckman JJ, Mazade RE, Hoon M, Bernstein AS, Romero-Aleshire MJ, Brooks HL, Eggers ED (2016) Early retinal neuronal dysfunction in diabetic mice: reduced light-evoked inhibition increases rod pathway signaling. Invest Ophthalmol Vis Sci 57:1418-1430. CrossRef Medline 
Mørkve SH, Veruki ML, Hartveit E (2002) Functional characteristics of non-NMDA-type ionotropic glutamate receptor channels in AII amacrine cells in rat retina. J Physiol 542:147-165. CrossRef Medline

Neher E, Stevens CF (1977) Conductance fluctuations and ionic pores in membranes. Annu Rev Biophys Bioeng 6:345-381. CrossRef Medline

Nowak L, Bregestovski P, Ascher P, Herbet A, Prochiantz A (1984) Magnesium gates glutamate-activated channels in mouse central neurones. Nature 307:462-465. CrossRef Medline

Ogden KK, Traynelis SF (2011) New advances in NMDA receptor pharmacology. Trends Pharmacol Sci 32:726-733. CrossRef Medline

Pachernegg S, Strutz-Seebohm N, Hollmann M (2012) GluN3 subunitcontaining NMDA receptors: not just one-trick ponies. Trends Neurosci 35:240-249. CrossRef Medline

Paoletti P, Vergnano AM, Barbour B, Casado M (2009) Zinc at glutamatergic synapses. Neurosci 158:126-136. CrossRef Medline

Paoletti P, Bellone C, Zhou Q (2013) NMDA receptor subunit diversity: impact on receptor properties, synaptic plasticity and disease. Nat Rev Neurosci 14:383-400. CrossRef Medline

Papouin T, Oliet SH (2014) Organization, control and function of extrasynaptic NMDA receptors. Philos Trans R Soc Lond B Biol Sci 369:20130601. CrossRef Medline

Parsons MP, Raymond LA (2014) Extrasynaptic NMDA receptor involvement in central nervous system disorders. Neuron 82:279-293. CrossRef Medline

Perin-Dureau F, Rachline J, Neyton J, Paoletti P (2002) Mapping the binding site of the neuroprotectant ifenprodil on NMDA receptors. J Neurosci 22:5955-5965. CrossRef Medline

Petralia RS, Wang YX, Hua F, Yi Z, Zhou A, Ge L, Stephenson FA, Wenthold RJ (2010) Organization of NMDA receptors at extrasynaptic locations. Neuroscience 167:68-87. CrossRef Medline

Poleg-Polsky A, Diamond JS (2016) NMDA receptors multiplicatively scale visual signals and enhance directional motion discrimination in retinal ganglion cells. Neuron 89:1277-1290. CrossRef Medline

Pologruto TA, Sabatini BL, Svoboda K (2003) ScanImage: flexible software for operating laser scanning microscopes. Biomed Eng Online 2:13. CrossRef Medline

Rauen T, Taylor WR, Kuhlbrodt K, Wiessner M (1998) High-affinity glutamate transporters in the rat retina: a major role of the glial glutamate transporter GLAST-1 in transmitter clearance. Cell Tissue Res 291:19-31. Medline

Sah P, Hestrin S, Nicoll RA (1989) Tonic activation of NMDA receptors by ambient glutamate enhances excitability of neurons. Science 246:815818. CrossRef Medline

Scimemi A, Fine A, Kullmann DM, Rusakov DA (2004) NR2B-containing receptors mediate cross talk among hippocampal synapses. J Neurosci 24:4767-4777. CrossRef Medline

Shepherd GM, Grillner S, eds (2018) Handbook of brain microcircuits, Ed 2. New York: Oxford UP.

Shimamoto K, Lebrun B, Yasuda-Kamatani Y, Sakaitani M, Shigeri Y, Yumoto N, Nakajima T (1998) DL-threo- $\beta$-benzyloxyaspartate, a potent blocker of excitatory amino acid transporters. Mol Pharmacol 53:195201. CrossRef Medline

Shipton OA, Paulsen O (2013) GluN2A and GluN2B subunit-containing NMDA receptors in hippocampal synaptic plasticity. Philos Trans R Soc Lond B Biol Sci 369:20130163. CrossRef Medline

Singer JH, Diamond JS (2003) Sustained $\mathrm{Ca}^{2+}$ entry elicits transient postsynaptic currents at a retinal ribbon synapse. J Neurosci 23:10923-10933. CrossRef Medline

Smart TG, Paoletti P (2012) Synaptic neurotransmitter-gated receptors. Cold Spring Harb Perspect Biol 4:a009662. CrossRef Medline

Smart TG, Xie X, Krishek BJ (1994) Modulation of inhibitory and excitatory amino acid receptor ion channels by zinc. Prog Neurobiol 42:393-441. CrossRef Medline

Stafford BK, Manookin MB, Singer JH, Demb JB (2014) NMDA and AMPA receptors contribute similarly to temporal processing in mammalian retinal ganglion cells. J Physiol 592:4877-4889. CrossRef Medline

Stevens ER, Esguerra M, Kim PM, Newman EA, Snyder SH, Zahs KR, Miller RF (2003) D-Serine and serine racemase are present in the vertebrate retina and contribute to the physiological activation of NMDA receptors. Proc Natl Acad Sci U S A 100:6789-6794. CrossRef Medline

Strettoi E, Dacheux RF, Raviola E (1990) Synaptic connections of rod bipo- lar cells in the inner plexiform layer of the rabbit retina. J Comp Neurol 295:449-466. CrossRef Medline

Strettoi E, Raviola E, Dacheux RF (1992) Synaptic connections of the narrow-field, bistratified amacrine cell (AII) in the rabbit retina. J Comp Neurol 325:152-168. CrossRef Medline

Strettoi E, Dacheux RF, Raviola E (1994) Cone bipolar cells as interneurons in the rod pathway of the rabbit retina. J Comp Neurol 347:139-149. CrossRef Medline

Sucher NJ, Kohler K, Tenneti L, Wong HK, Gründer T, Fauser S, WheelerSchilling T, Nakanishi N, Lipton SA, Guenther E (2003) N-methyl-Daspartate receptor subunit NR3A in the retina: developmental expression, cellular localization, and functional aspects. Invest Ophthalmol Vis Sci 44:4451-4456. CrossRef Medline

Sullivan SJ, Miller RF (2012) AMPA receptor-dependent, light-evoked D-serine release acts on retinal ganglion cell NMDA receptors. J Neurophysiol 108:1044-1051. CrossRef Medline

Swanger SA, Traynelis SF (2018) Synaptic receptor diversity revealed across space and time. Trends Neurosci 41:486-488. CrossRef Medline

Tetenborg S, Yadav SC, Hormuzdi SG, Monyer H, Janssen-Bienhold U, Dedek K (2017) Differential distribution of retinal $\mathrm{Ca}^{2+} /$ calmodulindependent kinase II (CaMKII) isoforms indicates CaMKII- $\beta$ and $-\delta$ as specific elements of electrical synapses made of connexin36 (Cx36). Front Mol Neurosci 10:425. CrossRef Medline

Tovar KR, McGinley MJ, Westbrook GL (2013) Triheteromeric NMDA receptors at hippocampal synapses. J Neurosci 33:9150-9160. CrossRef Medline

Traynelis SF, Wollmuth LP, McBain CJ, Menniti FS, Vance KM, Ogden KK, Hansen KB, Yuan H, Myers SJ, Dingledine R (2010) Glutamate receptor ion channels: structure, regulation, and function. Pharmacol Rev 62:405496. CrossRef Medline

Trexler EB, Li W, Massey SC (2005) Simultaneous contribution of two rod pathways to AII amacrine and cone bipolar cell light responses. J Neurophysiol 93:1476-1485. CrossRef Medline

Tzingounis AV, Wadiche JI (2007) Glutamate transporters: confining runaway excitation by shaping synaptic transmission. Nat Rev Neurosci 8:935-947. CrossRef Medline

Ullian EM, Barkis WB, Chen S, Diamond JS, Barres BA (2004) Invulnerability of retinal ganglion cells to NMDA excitotoxicity. Mol Cell Neurosci 26:544-557. CrossRef Medline

Veruki ML, Hartveit E (2002a) AII (rod) amacrine cells form a network of electrically coupled interneurons in the mammalian retina. Neuron 33: 935-946. CrossRef Medline

Veruki ML, Hartveit E (2002b) Electrical synapses mediate signal transmission in the rod pathway of the mammalian retina. J Neurosci 22:10558 10566. CrossRef Medline

Veruki ML, Mørkve SH, Hartveit E (2003) Functional properties of spontaneous EPSCs and non-NMDA receptors in rod amacrine (AII) cells in the rat retina. J Physiol 549:759-774. CrossRef Medline

Veruki ML, Mørkve SH, Hartveit E (2006) Activation of a presynaptic glutamate transporter regulates synaptic transmission through electrical signaling. Nat Neurosci 9:1388-1396. CrossRef Medline

Vicini S, Wang JF, Li JH, Zhu WJ, Wang YH, Luo JH, Wolfe BB, Grayson DR (1998) Functional and pharmacological differences between recombinant $N$-methyl-D-aspartate receptors. J Neurophysiol 79:555-566. CrossRef Medline

Vigh J, von Gersdorff H (2005) Prolonged reciprocal signaling via NMDA and GABA receptors at a retinal synapse. J Neurosci 25:11412-11423. CrossRef Medline

Wadiche JI, Arriza JL, Amara SG, Kavanaugh MP (1995) Kinetics of a human glutamate transporter. Neuron 14:1019-1027. CrossRef Medline

Wersinger E, Schwab Y, Sahel JA, Rendon A, Pow DV, Picaud S, Roux MJ (2006) The glutamate transporter EAAT5 works as a presynaptic receptor in mouse rod bipolar cells. J Physiol 577:221-234. CrossRef Medline

Williams K (1993) Ifenprodil discriminates subtypes of the N-methyl-Daspartate receptor: selectivity and mechanisms at recombinant heteromeric receptors. Mol Pharmacol 44:851-859. Medline

Wong EH, Kemp JA, Priestley T, Knight AR, Woodruff GN, Iversen LL (1986) The anticonvulsant MK- 801 is a potent $N$-methyl-D-aspartate antagonist. Proc Natl Acad Sci U S A 83:7104-7108. CrossRef Medline

Xin D, Bloomfield SA (1997) Tracer coupling pattern of amacrine and 
ganglion cells in the rabbit retina. J Comp Neurol 383:512-528. CrossRef Medline

Yasuda R, Nimchinsky EA, Scheuss V, Pologruto TA, Oertner TG, Sabatini BL, Svoboda K (2004) Imaging calcium concentration dynamics in small neuronal compartments. Sci STKE 2004:pl5. CrossRef Medline

Zandt B-J, Liu JH, Veruki ML, Hartveit E (2017) AII amacrine cells: quantitative reconstruction and morphometric analysis of electrophysiologically identified cells in live rat retinal slices imaged with multi-photon excitation microscopy. Brain Struct Funct 222:151-182. CrossRef Medline

Zandt B-J, Veruki ML, Hartveit E (2018) Electrotonic signal processing in AII amacrine cells: compartmental models and passive membrane prop- erties for a gap junction-coupled retinal neuron. Brain Struct Funct 223: 3383-3410. CrossRef Medline

Zhang J, Diamond JS (2009) Subunit- and pathway-specific localization of NMDA receptors and scaffolding proteins at ganglion cell synapses in rat retina. J Neurosci 29:4274-4286. CrossRef Medline

Zhou C, Dacheux RF (2004) AII amacrine cells in the rabbit retina possess AMPA-, NMDA-, GABA-, and glycine-activated currents. Vis Neurosci 21:181-188. CrossRef Medline

Zhou Y, Tencerová B, Hartveit E, Veruki ML (2016) Functional NMDA receptors are expressed by both AII and A17 amacrine cells in the rod pathway of the mammalian retina. J Neurophysiol 115:389-403. CrossRef Medline 